FACULDADE DE AGRONOMIA E MEDICINA VETERINÁRIA

Programa de Pós Graduação em Agronomia

\title{
VARIABILIDADE GENÉTICA DE LINHAGENS E CULTIVARES DE MELÃO UTILIZANDO MARCADORES MOLECULARES
}

\author{
Dissertação de mestrado \\ Nayara Carvalho \\ Orientadora: Nara Oliveira Silva Souza \\ Co-orientadora: Glaucia Salles Cortopassi Buso
}

$$
\begin{gathered}
\text { Brasília - DF } \\
2016
\end{gathered}
$$


FACULDADE DE AGRONOMIA E MEDICINA VETERINÁRIA

Programa de Pós Graduação em Agronomia

\title{
ANÁLISE DA VARIABILIDADE GENÉTICA EM LINHAGENS E CULTIVARES DE MELÃO UTILIZANDO MARCADORES MOLECULARES.
}

\begin{abstract}
Dissertação de mestrado apresentada à Universidade de Brasília como parte das exigências para obtenção do Grau de Mestre em Agronomia: Área de concentração: Produção Sustentável, Linha de Pesquisa: Recursos Genéticos e Melhoramento de Plantas.
\end{abstract}

Orientadora: Prof. Dr ${ }^{\mathrm{a}}$. Nara Oliveira Silva Souza

Co-Orientadora: Dr ${ }^{\mathrm{a}}$. Glaucia Salles Cortopassi Buso

Brasília - DF 


\title{
ANÁLISE DA VARIABILIDADE GENÉTICA EM LINHAGENS E CULTIVARES DE MELÃO UTILIZANDO MARCADORES MOLECULARES.
}

\author{
Dissertação de mestrado \\ apresentada à Universidade de Brasília \\ como parte das exigências para obtenção \\ do Grau de Mestre em Agronomia: Área \\ de concentração: Produção Sustentável, \\ Linha de Pesquisa: Recursos Genéticos e \\ Melhoramento de Plantas.
}

APROVADA EM: 29/02/ 2016.

Prof. Dr ${ }^{\mathrm{a}}$. Nara Oliveira Silva Souza - UnB

(Presidente) Orientadora 
FACULDADE DE AGRONOMIA E MEDICINA VETERINÁRIA

Programa de Pós Graduação em Agronomia

\section{DEDICATÓRIA}

Á Deus, meu companheiro SEMPRE.

Aos meus pais, minha admiração e meus exemplos para toda a vida.

"É muito melhor lançar-se em busca de conquistas grandiosas, mesmo expondo-se ao fracasso, do que alinhar-se com os pobres de espírito, que nem gozam muito nem sofrem muito, porque vivem numa penumbra cinzenta, onde não conhecem nem vitória, nem derrota." 
FACULDADE DE AGRONOMIA E MEDICINA VETERINÁRIA

Programa de Pós Graduação em Agronomia

\section{AGRADECIMENTOS}

À Deus, primeiro e sempre a Ele, que esteve ao meu lado e me deu forças para seguir adiante.

Á Universidade de Brasília (UnB), por possibilitar a realização do meu mestrado e ter me acolhido como aluna desde a graduação.

À Empresa Brasileira de Pesquisa Agropecuária (EMBRAPA), pela oportunidade de aperfeiçoamento profissional.

À EMBRAPA - Recursos Genéticos e Biotecnologia (CENARGEN), pelo apoio logístico e financeiro para a realização desta pesquisa.

À CAPES pela concessão da minha bolsa, que me manteve durante todo o período de 2 anos da minha pesquisa.

À minha orientadora Nara Souza, pela atenção, paciência, direcionamento e educação, sempre.

À minha co-orientadora Glaucia Buso, pela oportunidade profissional, pelo apoio financeiro, pelos esclarecimentos e ensinamentos pessoais.

Aos pesquisadores Valter Rodrigues Oliveira e Mateus Figueiredo Santos, por cederem o material vegetal por meio de coletas para o desenvolvimento da minha pesquisa.

Ao pesquisador Fábio Gelape Faleiro, por quem tenho grande estima, e à Prof. Michelle Souza Vilela, pela disposição e respeito e por aceitarem o convite para avaliação da minha dissertação.

À Equipe LGV (Laboratório de Genética Vegetal), por disponibilizar suas dependências e materiais para a realização deste trabalho.

À técnica Zilneide, pela organização e disponibilidade, e pelos famosos "ginetes baianos" que adoçaram minha caminhada.

À analista e amiga Lorena, pela ajuda no manejo de diversos softwares de avaliação genética, pela convivência e pelas conversas esclarecedoras e reconfortantes.

Aos pesquisadores Marco Antônio e Márcio Moretshzon, pela disponibilidade e boa vontade nos esclarecimentos, especialmente ao Marco, pelos ensinamentos e ajuda com todas as técnicas utilizadas.

Aos pesquisadores Marília e Peter, por sanarem diversas dúvidas em relação ao estudo.

Ao estagiário Felipe Mont'Alvão, pela dedicação muitas vezes árdua, ajuda extrema e essencial nas atividades desempenhadas no LGV para o desenvolvimento da minha dissertação, e pela amizade sempre presente. 
FACULDADE DE AGRONOMIA E MEDICINA VETERINÁRIA

\section{Programa de Pós Graduação em Agronomia}

Ao colega Paulo, pelo descobrimento de que o aprender é mais fácil quando se ensina.

Às colegas Bruna e Natasha, pelo compartilhamento de conhecimento, pelos esclarecimentos sempre que necessário, e pela companhia nas jornadas noturnas no laboratório.

Às amigas Manuela e Cecília, pela cumplicidade e por tantos anos de desabafos. Por me ensinarem o verdadeiro significado da palavra amizade.

Aos amigos João Lucas e Anádria, pela cumplicidade, compartilhamento de tantos ensinamentos profissionais e pessoais, pelos desabafos, pela companhia que sempre fez a diferença nos meus dias de trabalho árduo, pela alegria e por tornarem minha jornada mais doce e fácil.

Aos meus pais, pela dedicação e amor e aos meus irmãos pela compreensão.

Ao meu companheiro Ronaldo, pela paciência nas horas difíceis, pela dedicação e apoio moral, pela ajuda com minhas incontáveis planilhas e publicações, pela cumplicidade e afinidade de sempre, e por me proporcionar tanto amor e compreensão.

MEU MUITO OBRIGADA A TODOS! 
FACULDADE DE AGRONOMIA E MEDICINA VETERINÁRIA

Programa de Pós Graduação em Agronomia

\section{RESUMO}

O agronegócio do melão no Brasil teve um crescimento de mais de $800 \%$ nas últimas décadas, gerando muitos empregos, sobretudo na região Nordeste, que concentra mais de 95,8\% da produção nacional, contribuindo para o desenvolvimento socioeconômico da região. Os estudos de variabilidade genética auxiliam programas de melhoramento possibilitando a obtenção de populações com heterose e híbridos superiores. Marcadores moleculares SSR (Simple Sequence Repeats) e ISSR (Inter Simple Sequence Repeats) têm sido utilizados como uma eficiente ferramenta para análises de variabilidade genética. Dessa forma, os objetivos desse trabalho foram avaliar a variabilidade genética de linhagens de melão do tipo Pele de Sapo, Amarelo e Cantaloupe, por meio do uso de marcadores moleculares SSR e ISSR, e avaliar a base genética de cultivares de melão pertencentes aos grupos Inodorus e Cantaloupesis, utilizando marcadores moleculares SSR. O estudo da divergência genética das linhagens pertencentes aos três tipos varietais revelou ampla variabilidade genética. Os marcadores SSR amplificaram um total de 45, 78 e 103 alelos para os genótipos Pele de Sapo, Amarelo e Cantaloupe respectivamente. Os marcadores ISSR complementaram a análise dos genótipos Pele de Sapo apresentando um total de 74 bandas polimórficas. Ambos marcadores foram eficientes na análise da variabilidade genética possibilitando sugestões dos melhores cruzamentos para obtenção de híbridos superiores e com maior heterose. Para o estudo das cultivares, foram selecionados 44 primers SSR que amplificaram um total de 204 alelos. O dendrograma gerado para as 73 cultivares agrupou os genótipos em 2 principais grupos, não havendo associação com a classificação dos genótipos no agrupamento. Contudo, o número de marcadores SSR foi o suficiente para predizer ampla variabilidade genética entre as cultivares estudadas já que nenhuma dessas mostrou similaridade genética igual a 1. Foi identificado um conjunto de 17 primers que foram úteis na distinção das 73 cultivares com índice de 99,99\% de exclusão de parentais. Esses primers podem ser utilizados em pesquisas posteriores com as cultivares analisadas nesse estudo, bem como, em situações de proteção de cultivares para o agronegócio do melão no Brasil, sendo importante ferramenta na distinção efetiva e rápida dos genótipos, podendo também ser utilizados em situações de disputas comerciais.

Palavras-Chave: Cucumis melo L., Variabilidade genética, Linhagens, Cultivares, SSR, ISSR. 
FACULDADE DE AGRONOMIA E MEDICINA VETERINÁRIA

Programa de Pós Graduação em Agronomia

\begin{abstract}
Melon agribusiness in Brazil grew by over $800 \%$ in recent decades, creating many jobs, especially in the Northeast region, which accounts for more than $95.8 \%$ of national production, contributing to the socioeconomic development of the region. Studies of genetic variability assist breeding programs making it possible to obtain populations with significant heterosis and superior hybrids. Molecular markers SSR (Simple Sequence Repeats) and ISSR (Inter Simple Sequence Repeats) have been used as an efficient tool for genetic variability analysis. That way, the objectives of this study were to evaluate the genetic variability of melon lines of type Pele de Sapo, Yellow and Cantaloupe, through the use of molecular markers SSR and ISSR, and assess the genetic basis of melon cultivars belonging to Inodorus and Cantaloupesis groups, by using SSR molecular markers. The study of genetic similarity of the lines belonging to the three varietal types showed wide genetic variability. The SSR markers amplified a total of 45, 78 and 103 alleles for the Pele de Sapo, Cantaloupe and Yellow genotypes respectively. ISSR complemented the analysis of genotypes Pele de Sapo and presented a total of 74 polymorphic bands. Both markers were efficient in the analysis of genetic variability allowing suggestions of the best crosses to obtain superior hybrids and more heterosis. For the study of cultivars, 44 SSR markers were selected and amplified a total of 204 alleles. The dendrogram generated for the 73 cultivars grouped genotypes in two main groups, there was no association with the type classification of the genotypes in the group. However, the number of SSR markers was enough to predict high genetic variability among cultivars, since none of them showed genetic similarity equal to 1.A set of 17 primers were useful in distinguishing the 73 cultivars and has been identified with an index $99 \%$ parental exclusion. These primers can be used in further research with the cultivars analyzed in this study as well, can help to protect them and it is important tool for effective and fast distinction of genotypes. The results were satisfactory allowing to predict a wide genetic base among genotypes representing major source of genetic variability for the national cultivars germplasm.
\end{abstract}

Keywords: Cucumis melo L., Genetic variability, Lines, cultivars, SSR, ISSR . 
FACULDADE DE AGRONOMIA E MEDICINA VETERINÁRIA

Programa de Pós Graduação em Agronomia

\section{LISTA DE TABELAS}

\section{REFERENCIAL TEÓRICO}

Tabela 1 Composição nutritiva do melão em $100 \mathrm{~g}$ de polpa. 18

Tabela 2 Principais tipos comerciais de melão, variedade botânica e alguns exemplos de híbridos comerciais cultivados no Nordeste brasileiro. .23

\section{CAPÍTULO 1}

Tabela 3 Lista com as sequências (forward e reverse) e temperaturas de anelamento otimizadas dos primers SSR polimórficos utilizados para as reações com os genótipos dos três tipos de melão analisados

Tabela 4 Medidas descritivas para estudos de variabilidade baseados nos marcadores SSR polimórficos em 58 genótipos de melão do tipo Pele de Sapo estimados pelo software GDA .75

Tabela 5 Lista com as sequências e temperaturas de anelamento dos primers ISSR polimórficos utilizados para as reações com os genótipos de melão do tipo Pele de Sapo analisados

Tabela 6 Medidas descritivas para estudos de variabilidade baseados nos marcadores SSR polimórficos em 141 genótipos de melão do tipo Amarelo estimados pelo software GDA

Tabela 7 Medidas descritivas para estudos de variabilidade baseados nos marcadores SSR polimórficos em 56 genótipos de melão do tipo Cantaloupe estimados pelo software GDA .88

\section{CAPÍTULO 2}

Tabela 8 Lista de melões Inodorus e PIs utilizados nesse estudo .98

Tabela 9 Lista de melões Cantaloupensis utilizados nesse estudo. 100 
FACULDADE DE AGRONOMIA E MEDICINA VETERINÁRIA

Programa de Pós Graduação em Agronomia

Tabela 10 Lista com as sequências (forward e reverse) e temperaturas de anelamento otimizadas do primers SSR polimórficos utilizados para as reações com todos os acessos de melão analisados 104

Tabela 11 Medidas descritivas para estudos de variabilidade baseados nos 44 marcadores SSR polimórficos em 73 cultivares de melão pertencentes aos grupos Inodorus

e Cantaloupenssis, estimados pelo software Cervus......................................111 
FACULDADE DE AGRONOMIA E MEDICINA VETERINÁRIA

Programa de Pós Graduação em Agronomia

\section{LISTA DE FIGURAS}

\section{REFERENCIAL TEÓRICO}

Figura 1 Principais tipos de melão.

\section{CAPÍTULO 1}

Figura 2 Primer CM102 - Um dos 18 primers SSR polimórficos para os 58 genótipos Pele de Sapo. . .73

Figura 3 Dendrograma das 58 linhagens gerado a partir da análise de 18 primers SSR.....77

Figura 4 Primer59Zm - Um dos 13 primers ISSR polimórficos para os 58 genótipos Pele de Sapo .78

Figura 5 Dendrograma das 58 linhagens gerado a partir da análise de 74 marcadores ISSR.

Figura 6 Primer CM43 - Um dos 35 primers SSR polimórficos para os 141 genótipos Amarelo. 82

Figura 7 Dendrograma das 141 linhagens gerado a partir da análise de 35 primers SSR....86

Figura 8 Primer CM320 - Um dos 47 primers SSR polimórficos para os 56 genótipos Cantaloupe.

Figura 9 Dendrograma das 56 linhagens gerado a partir da análise de 47 primers SSR.....91

\section{CAPÍTULO 2}

Figura 10 Primer CM303 - Um dos 44 primers polimórficos para as 73 cultivares e os 15 PIs. 109

Figura 11 Exemplo de gel duplex com ótima resolução de banda 114

Figura 12 Dendrograma das 73 cultivares gerado a partir da análise de 44 primers SSR...116

Figura 13 Dendrograma das 73 cultivares e 15 PIs gerado a partir da análise de 44 primers SSR. 
FACULDADE DE AGRONOMIA E MEDICINA VETERINÁRIA

Programa de Pós Graduação em Agronomia

\section{Sumário}

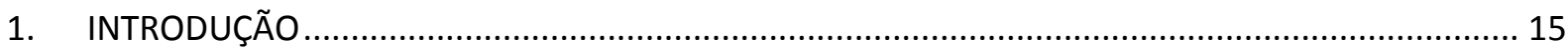

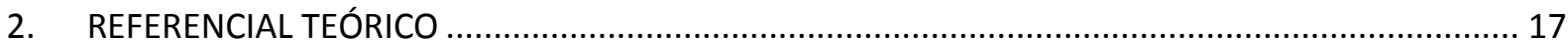

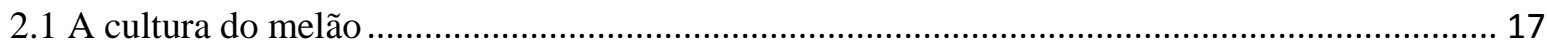

2.2 Classificação botânica e aspectos socioeconômicos ................................................................... 19

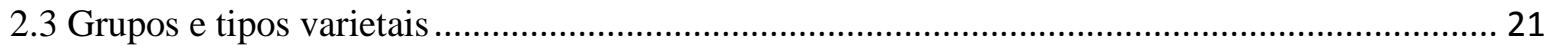

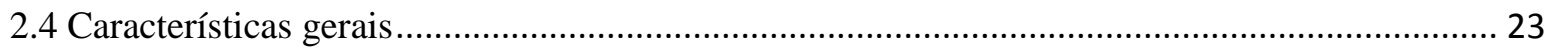

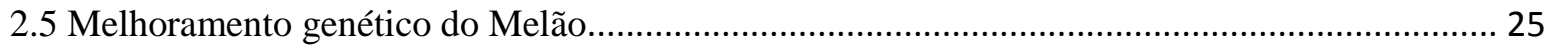

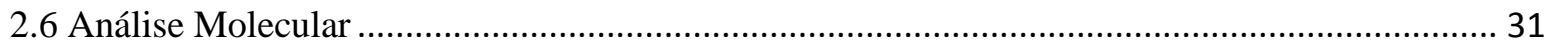

2.7 PCR

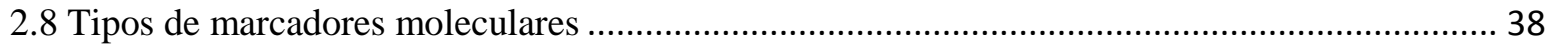

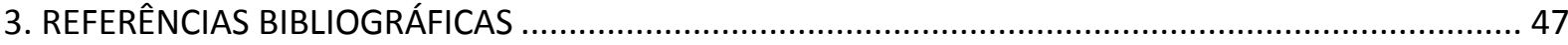

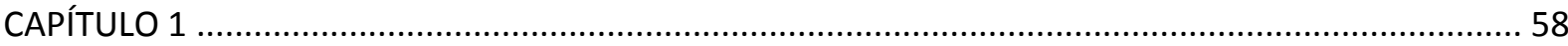

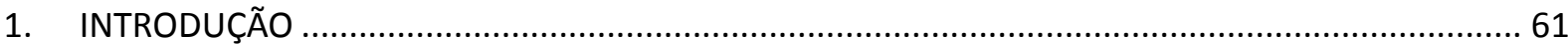

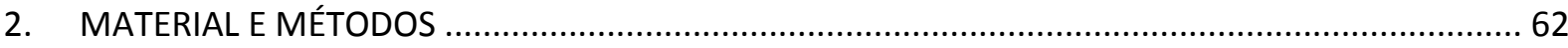

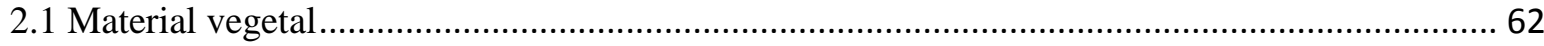

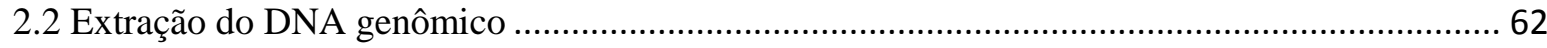

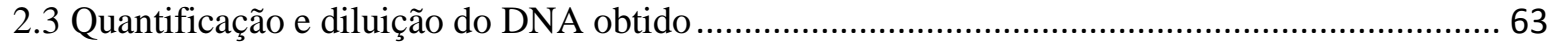

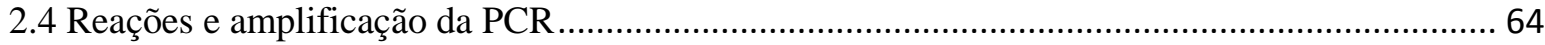

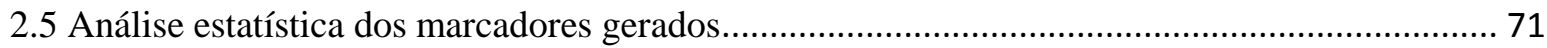

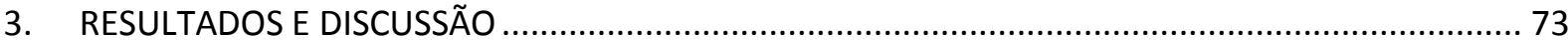

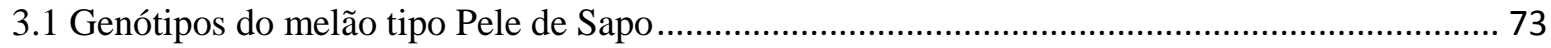

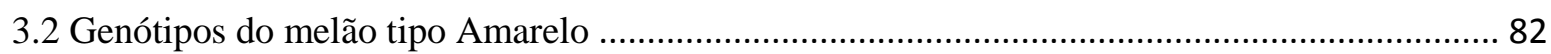

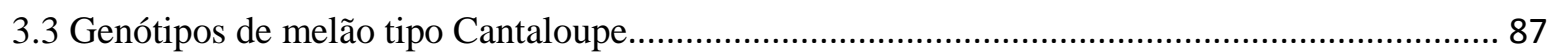

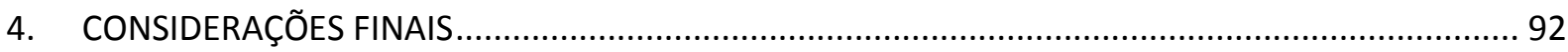

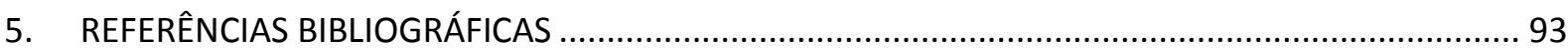

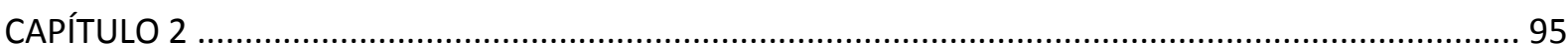

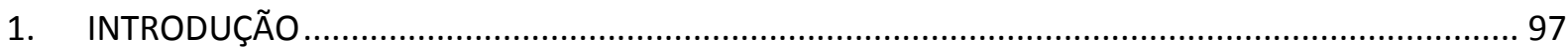

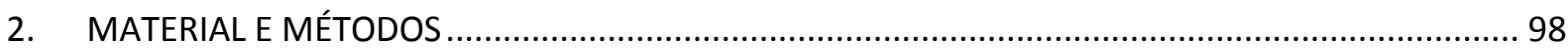

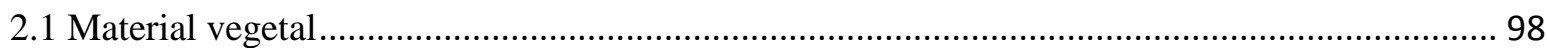

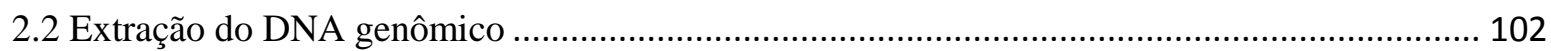

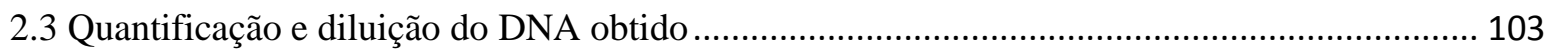

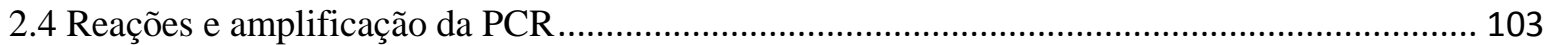


FACULDADE DE AGRONOMIA E MEDICINA VETERINÁRIA

Programa de Pós Graduação em Agronomia

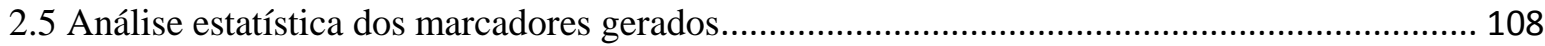

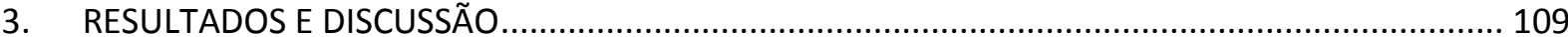

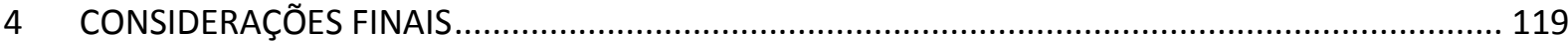

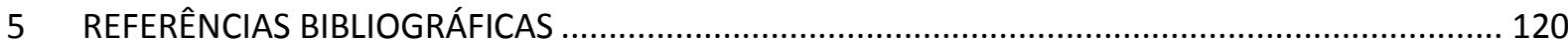


FACULDADE DE AGRONOMIA E MEDICINA VETERINÁRIA

Programa de Pós Graduação em Agronomia

\section{INTRODUÇÃO}

O melão é um fruto que tem grande representatividade no mercado internacional da fruticultura, e especialmente no Brasil, onde grande parte da produção é destinada à exportação. Segundo dados da FAO (2009), nas últimas duas décadas, o agronegócio do melão no Brasil teve um crescimento de mais de $800 \%$ (FAO, 2012), gerando muitos empregos, sobretudo na região Nordeste, que apresenta condições edafoclimáticas favoráveis à produção do fruto, sendo a principal região produtora do País e contribuindo com mais de 90\% da produção nacional. Dessa forma, a produção do fruto favorece o desenvolvimento socioeconômico nessa região, que apresenta carência de recursos e oportunidades.

A produção nacional de melão tem crescido significativamente alcançando aproximadamente 500 mil toneladas por ano com exceção do ano de 2013, em que a produção teve um decréscimo de 10 mil toneladas se comparada ao ano anterior, devido, entre outros fatores, à menor área plantada (IBGE, 2014). No ano de 2009 o fruto passou a ser o principal em valor exportado (IBGE, 2010).

Além dos avanços no manejo do solo, fitossanitário, irrigação, adubação e uso de tecnologias modernas, o uso de cultivares melhoradas geneticamente de meloeiro tem representado grande incremento para o aumento da produtividade e melhoria da qualidade dos frutos, sendo a forma mais sustentável para aumentar a competitividade dos mesmos no mercado internacional.

Os marcadores morfológicos são amplamente utilizados no melhoramento vegetal para caracterização e distinção de genótipos, e associados ao uso de marcadores moleculares, podem gerar informações importantes, que auxiliam no melhoramento convencional. Dessa forma, estudos nas áreas do melhoramento e recursos genéticos, tornam-se necessários, uma vez que a demanda por frutos de qualidade superior tem aumentado a cada ano. A expressão de características favoráveis ao produtor, e em longo prazo, ao consumidor, depende de diversos fatores ligados ao cultivo, mas sobretudo, de características advindas de recursos genéticos e técnicas biotecnológicas modernas, que auxiliam os cruzamentos e a produção de 
FACULDADE DE AGRONOMIA E MEIDICINA VETERINÁRIA

Programa de Pós Graduação em Agronomia

variedades superiores. Portanto, é necessário o estudo da variabilidade genética, para melhor compreensão das relações genéticas inter e intra-específicas.

Assim, é possível que com a maior oferta de melão, ocorra também a modificação do hábito de consumo, inserindo no mercado nacional outros tipos de frutos para competir com o melão amarelo, gerando demanda para o melhoramento genético (PAIVA, 1999).

No Brasil, o sucesso da cultura do melão está associado a utilização de híbridos simples uniformes e produtivos, entretanto, a maioria dos híbridos cultivados comercialmente tem origem fora do país apresentando evidentes problemas de adaptação, com forte redução no ciclo e menor teor de sólidos solúveis. Assim, embora a qualidade dos frutos nacionais tenha evoluído nos últimos anos, ainda deve melhorar muito em termos de resistência a pragas e doenças, teor de sólidos solúveis e padrão comercial dos frutos demandado no mercado (ARAGÃO, 2011).

Levando em consideração o cenário da produção nos últimos anos, percebe-se a grande importância mundial do melão, que contribui significativamente para o mercado da fruticultura, sobretudo no Brasil, onde a maioria da produção é destinada à exportação, proporcionando grande ganho econômico para o país.

Estudos de divergência genética entre linhagens que façam uso de marcadores moleculares poupam esforços de polinizações manuais realizadas por melhoristas para identificação de parentais divergentes, e direcionam os melhores cruzamentos afim de se obter recombinações favoráveis gerando híbridos superiores.

A espécie C. melo apresenta uma grande diversidade fenotípica nas suas variedades, o que não implica necessariamente em ampla variabilidade genética, principalmente porque o melhoramento se baseia no melão do tipo Amarelo, que representa 98\% da preferência nacional. Assim sendo, pode ter ocorrido erosão genética havendo a possibilidade de que a base genética das cultivares comerciais esteja relativamente estreita. 
FACULDADE DE AGRONOMIA E MEDICINA VETERINÁRIA

Programa de Pós Graduação em Agronomia

Dessa forma, o presente trabalho tem como objetivos: Avaliação da variabilidade genética de linhagens de melão do tipo Pele de Sapo, Amarelo e Cantaloupe, por meio do uso de marcadores moleculares SSR e ISSR; e a avaliação da base genética de cultivares de melão pertencentes aos grupos Inodorus e Cantaloupesis, por meio do uso de marcadores moleculares SSR.

\section{REFERENCIAL TEÓRICO}

2.1 A cultura do melão

O melão é o fruto do meloeiro (Cucumis melo L.), também conhecido como melon (inglês, francês), melón (espanhol) ou melone (italiano), é uma planta herbácea muito antiga, registrada em pinturas egípcias de 2500 a.C. e também citada na Bíblia no antigo testamento. O seu consumo é cada vez mais ascendente no Brasil, é também muito consumido na Europa, Estados Unidos e Japão (ALMEIDA, 2006).

Há muitas divergências quanto à origem da espécie, que compreendem Índia (DE CANDOLE, 1882), África (WITHAKER \& DAVIS, 1962), Ásia (ASHIZAWA \& YAMATO, 1965) e China (PANGALO, 1930), mas as regiões mais prováveis são o sudoeste da África e a região peninsular da Índia (MALLICK \& MASSUI, 1986).

Nas Américas, o melão foi introduzido por intermédio de Cristóvão Colombo e a partir dessa época, passou a ser utilizado pelos índios, sendo rapidamente espalhado por todo o continente (COSTA \& PINTO, 1977). No Brasil, a introdução foi feita por imigrantes europeus e os Estados do Rio Grande do Sul e São Paulo foram, possivelmente, o seu primeiro centro de cultivo no país (COSTA et al., 2000). A partir da década de 1980, começou a ser cultivado na região Nordeste devido às condições climáticas favoráveis para o desenvolvimento da espécie o que propiciou a colheita de três safras por ano. O ciclo vegetal de cultivares introduzidas nessa região foi reduzido, tornando-se mais precoces.

Frutas e hortaliças são importantes componentes de uma dieta saudável e seu consumo em quantidade adequada pode reduzir o risco de doenças cardiovasculares e alguns 
FACULDADE DE AGRONOMIA E MEIDICINA VETERINÁRIA

Programa de Pós Graduação em Agronomia

tipos de câncer (LOCK et al., 2005). Dessa forma, o melão torna-se um grande aliado nas dietas, pois possui cerca de $83 \%$ de água, sendo um fruto muito refrescante e hidratante. É rico em minerais como o cálcio, que é fortalecedor dos ossos, o potássio, que ajuda na eliminação de resíduos celulares e auxilia na manutenção das fibras musculares e dos nervos, e o magnésio, que é levemente laxante sendo eficaz contra a prisão de ventre (ROBINSON \& DECKER-WALTERS, 1997).

A tabela 1 apresenta a composição nutritiva do melão que possui valor energético relativamente baixo, 20 a $62 \mathrm{Kcal} / 100 \mathrm{~g}$ de polpa (ROBINSON \& DECKER-WALTER, 1997), também é rico em vitamina A, que protege as células contra os radicais livres, é importante para a visão, e atua na função de órgãos reprodutivos sobretudo, feminino, prevenindo TPM (Tensão pré-menstrual) e regularizando o ciclo menstrual (ROBINSON \& DECKER-WALTER, 1997). Em cultivares de polpa laranja o $\beta$-caroteno é o principal componente com os teores variando de 4.0 até $34 \mu \mathrm{g} / \mathrm{g}$ enquanto a xantofila é o pigmento predominante em melões de polpa verde (LESTER \& EISCHEN, 1996). O betacaroteno é um precursor da vitamina A e importante estimulante do sistema imunológico, além de ser antioxidante (ROBINSON \& DECKER-WALTER, 1997).

Outras propriedades medicinais incluem efeito calmante, refrescante, antioxidante, diurético, antibiótico e mineralizante. É recomendado no controle de diversas doenças, como a gota, reumatismo, artrite, colite, prisão de ventre, afecções renais, cistite, anemia, hemorroidas, dentre outros (ROBINSON \& DECKER-WALTER, 1997).

Tabela 1: Composição nutritiva do melão em $100 \mathrm{~g}$ de polpa.

\begin{tabular}{lccr}
\hline Composição & Conteúdo & Composição & Conteúdo \\
\hline Água & $83 \%$ & Riboflavina & $0,02 \mathrm{mg}$ \\
Calorias & $62,0 \mathrm{Kcal}$ & Niacina & $0,50 \mathrm{mg}$ \\
Proteínas & $0,60 \mathrm{~g}$ & Cálcio & $10,00 \mathrm{mg}$ \\
Gorduras & $0,10 \mathrm{~g}$ & Fósforo & $12,00 \mathrm{mg}$ \\
Carboidratos & $15,70 \mathrm{~g}$ & Sódio & $9,00 \mathrm{mg}$ \\
Fibra & $0,30 \mathrm{~g}$ & Magnésio & $13,10 \mathrm{mg}$ \\
Vitamina A & $1540 \mathrm{Ul}$ & Potássio & $188,00 \mathrm{mg}$ \\
Vitamina C & $16,0 \mathrm{mg}$ & Ferro & $0,30 \mathrm{mg}$ \\
Tiamina & $0,03 \mathrm{mg}$ & Zinco & $0,13 \mathrm{mg}$ \\
\hline
\end{tabular}

Fonte: Robinson \& Decker-Walters (1997). 
FACULDADE DE AGRONOMIA E MEDICINA VETERINÁRIA

Programa de Pós Graduação em Agronomia

\subsection{Classificação botânica e aspectos socioeconômicos}

A espécie Cucumis melo L., pertence à família Cucurbitaceae, mesma família das abóboras e da melancia, ao gênero Cucumis, mesmo gênero do pepino que compreende cerca de 38 espécies conhecidas, à tribo Melothrieae e subtribo Cucumerinae (SILVA \& COSTA 2003). É um fruto de grande popularidade, muito apreciado no mundo e de consumo ascendente no Brasil, tendo grande representatividade no mercado interno e externo.

O mercado internacional do fruto tem crescido constantemente e as exportações brasileiras têm acompanhado esse nível, tendo uma participação significativa ao longo dos últimos anos. A produção mundial em 2011 foi de 27,3 milhões de toneladas, tendo a China apresentado 47,94\% desse montante. Entretanto, quase toda essa produção chinesa é destinada ao mercado interno (APEX, 2014). Nesse mesmo ano, a União Europeia comandou a lista dos maiores exportadores mundiais do fruto, sendo a Espanha e a Holanda, responsáveis pelo maior volume em exportação; em segundo lugar aparece a América central e Caribe e em terceiro, a América do Sul, onde o Brasil tem grande representatividade com 8,3\% das exportações mundiais, ocupando o $5^{\circ}$ lugar no ranking dos maiores exportadores do fruto, o que indica que, a maioria da produção do Brasil é destinada à exportação (APEX, 2014).

Com relação às importações, a União Europeia apareceu novamente em primeiro lugar, apresentando 57,7\% das importações em 2011 seguida pela América do Norte, Ásia e Oceania. Nesse mesmo ano, os Estados Unidos e Holanda, apareceram como maiores importadores de melão com 20,7 e 11,8\% respectivamente (APEX, 2014).

Em 2012, a China também ocupou o primeiro lugar no ranking dos maiores produtores de melão do mundo, produzindo cerca de 17.500.000 toneladas do fruto, seguida da Turquia (1.708.415 toneladas) e do Irã (1.450.000 toneladas). O Brasil apareceu em $9^{\circ}$ lugar com 575.386 toneladas, gerando aproximadamente $\mathrm{R} \$ 475$ milhões para quase 220 mil produtores, sendo 70\% dessa produção destinada ao mercado externo. Em 2013, a produção teve um decréscimo de aproximadamente 10 mil toneladas, passando para 565,9 mil 
FACULDADE DE AGRONOMIA E MEIDICINA VETERINÁRIA

Programa de Pós Graduação em Agronomia

toneladas, devido principalmente, à redução da área plantada que passou de 22.810 ha em 2012 para 22.062 ha em 2013 (IBGE, 2014).

No Brasil, a região Nordeste concentra a produção $(95,8 \%)$ apresentando relativa expressão econômica, onde se destacam os Estados do Ceará (35\%), Rio Grande do Norte $(46,6 \%)$, Pernambuco $(3,5 \%)$ e Bahia $(10,5 \%)$, como os maiores produtores da região, sendo os pólos irrigados do Vale do São Francisco, Açu-Mossoró - RN e do Jaguaribe - CE os centros de maior expressão (MENEZES et al., 2001; IBGE, 2010).

A maior produção no Brasil ocorre entre os meses de setembro e março, com picos de safra entre setembro e janeiro, justamente o período da entressafra mundial. A região nordeste apresenta condições edafoclimáticas favoráveis à produção de melão, produzindo até três safras anuais, o que contribuí para que esta seja a maior região produtora do Brasil. Em 2010, o nordeste produziu 456.686 toneladas do fruto, aproximadamente $95 \%$ da produção total do país neste mesmo ano (IBGE, 2010). No ano de 2012 os estados do Ceará $(58,6 \%)$ e Rio Grande do Norte (40,3\%) representaram juntos 98,9\% da produção nacional (APEX, 2014). A grande vantagem da região nordeste para o cultivo da espécie é a pequena ocorrência de chuvas que favorece a baixa incidência de doenças e a melhor qualidade dos frutos (COSTA et al., 2000; PAIVA et al., 2002).

As exportações brasileiras de melão destinam-se basicamente à União Europeia representando 98,5\% do total exportado em 2011 e 97,7\% em 2012. Para esse mesmo período, a Holanda e Reino Unido absorveram juntos mais de $70 \%$ das exportações brasileiras. As principais variedades do grupo Inodorus exportadas pelo Brasil são o amarelo e o pele de sapo e do aromático, o cantaloupe, charentais, gália, honey dew e orange flesh (APEX, 2014).

Com relação à comercialização, verifica-se que no mercado interno, são preferidos os frutos maiores, com peso unitário de 2,0 kg, tolerando-se uma variação de 1,0 a 2,0 kg (FILGUEIRA, 2008). 
FACULDADE DE AGRONOMIA E MEIDICINA VETERINÁRIA

Programa de Pós Graduação em Agronomia

2.3 Grupos e tipos varietais

O melão é uma espécie altamente polimórfica, sendo a mais variável do gênero Cucumis (KARCHI, 2000). Naudin (1859), ao trabalhar com uma coleção de 2000 espécimes, dividiu a espécie $C$. melo em dez variedades. O trabalho pioneiro de Naudin serviu de base para todas as outras classificações e estudos subsequentes (COGNIAUX \& HARMS, 1924; PANGALO, 1933; FILOV, 1960; WHITAKER \& DAVIS, 1962; MUNGER \& ROBINSON, 1991; PITRAT et al., 2000). A classificação sugerida por Robinson \& Dereck-Walters (1997) é a mais utilizada na literatura atual e divide a espécie $C$. melo em seis variedades ou grupos botânicos: Cantaloupensis, Inodorus, Conomon, Dudaim, Flexuosus, e Momordica.

No Brasil, atualmente, as variedades comerciais de melão pertencem a dois grupos:

- Inodoros (C. melo var. Inodorus Naud): Os frutos apresentam casca lisa ou levemente enrugada, de coloração geralmente amarela, branca ou verde escura e formato mais oval; Possuem elevada resistência pós colheita; Não possuem aroma (inodoros), os frutos são do tipo não climatéricos e geralmente, são maiores e mais tardios que os aromáticos. Neste grupo encontram-se os melões do tipo Amarelo, Pele de Sapo e Honey Dew (ROBINSON \& DERECKWALTERS, 1997; MUNGER \& ROBINSON, 1991; NUNES et al., 2004).

- Aromáticos (C. melo var. Cantalupensis Naud): Possuem fragrância/aroma marcantes e característicos, polpa geralmente de cor salmão/alaranjada, elevado brix; Frutos do tipo climatérico, porém, que apresentam baixa resistência pós colheita, geralmente rendilhados ou com suturas. Os melões Cantaloupe, Gália e Charentais fazem parte desse grupo (ROBINSON \& DERECK-WALTERS, 1997; MUNGER \& ROBINSON, 1991; NUNES et al., 2004).

Visando facilitar a comercialização, os melões cultivados são agrupados numa classificação comercial denominada tipo, que define um grupo de cultivares com características semelhantes (Mc CREIGHT et al., 1993). Para o mercado brasileiro, essa 
FACULDADE DE AGRONOMIA E MEDICINA VETERINÁRIA

Programa de Pós Graduação em Agronomia

classificação compreende principalmente os tipos: Amarelo, Pele de Sapo, Honey Dew, Cantaloupe, Gália e Charentais (ARAGÃO, 2011).

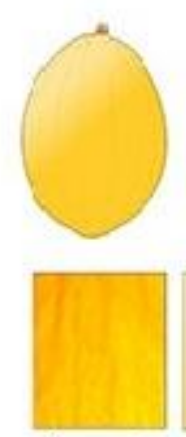

Amanelo
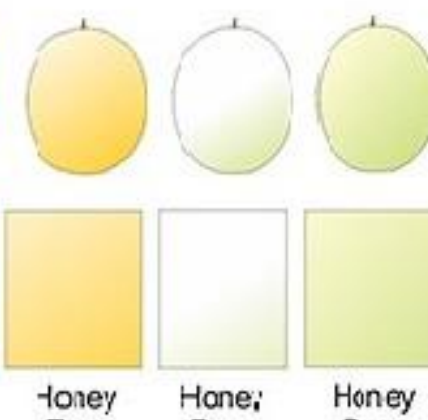

Dew
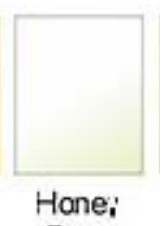

Dew

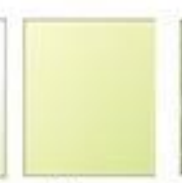

Honey

Dew
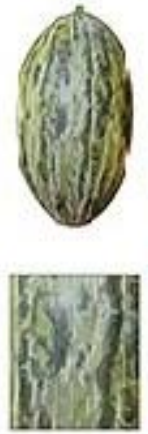

Pele

Sto
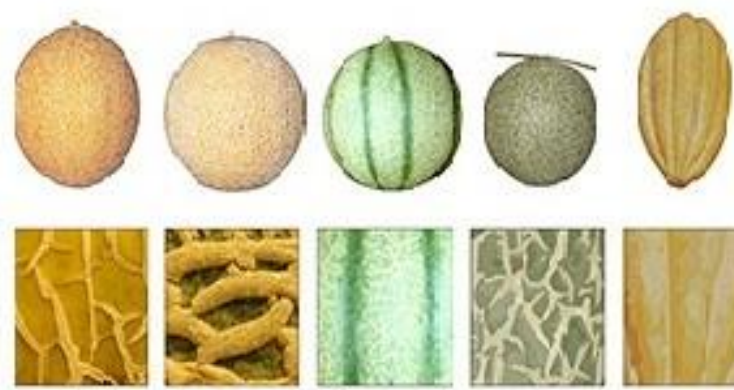

Gélia

Cantaloupe Charentais

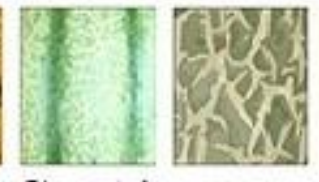

Net Melon

Figura 1: Principais tipos de melão (CEAGESP, 2010).

As cultivares de melão são resultantes de hibridações e seleção em ambientes variáveis e de programas intensivos de melhoramento genético que incorporam genes desejáveis nas variedades, já que o cruzamento delas é perfeitamente viável (MENEZES et al., 2000).

Percebe-se uma complicação na identificação de variedades porque muitas podem ser duplicações da mesma variedade com diferentes denominações (PAIVA et al., 2002). Alguns autores acreditam que, de maneira geral, a variação nos frutos de melão não é tão ampla quanto é apresentada nas partes vegetativas e reprodutivas da planta. Conforme estes autores, a ampla variação apresentada pelos tipos Cantaloupe, é resultado da seleção para adaptação a diferentes áreas geográficas e condições ecológicas. Provavelmente, quando os resultados de estudos moleculares destes grupos de melão estiverem disponíveis, poderá ocorrer outra reorganização (SILVA \& COSTA, 2003). Munger \& Robinson (1991) sugeriram que C. melo cantaloupensis e C.melo reticulatus, formassem um único grupo, tratado aqui como melões aromáticos. 
FACULDADE DE AGRONOMIA E MEDICINA VETERINÁRIA

Programa de Pós Graduação em Agronomia

No Brasil, os melões mais cultivados pertencem ao grupo Inodorus tipo amarelo (também conhecido como Valenciano ou Espanhol), entretanto, há uma tendência ao aumento da demanda por melões aromáticos (APEX, 2014; COSTA et al., 2000). As razões para a preferência do melão do tipo Amarelo estão no menor custo de produção, na facilidade de cultivo, na alta produtividade e longa vida pós-colheita (NUNES et al., 2004). Entre os Amarelos, destacam-se como os mais cultivados as cultivares "Goldex" e "Natal". Entre os cantaloupes o "Caribbean Gold" e o melão Pele de sapo "Sancho" ocupam quase toda a área plantada. Ainda vale ressaltar outros melões, como o "Caipira" e os "Net melons", que também são cultivados no Brasil, mas com importância econômica restrita a áreas específicas do país (ARAGÃO, 2011).

Tabela 2: Principais tipos comerciais de melão, variedade botânica e alguns exemplos de híbridos comerciais cultivados no Nordeste brasileiro.

\begin{tabular}{lll}
\hline $\begin{array}{l}\text { Tipo } \\
\text { Comercial }\end{array}$ & Variedade botânica & Híbridos comerciais \\
\hline Amarelo & C. melo var inodorus Naud & Goldex*, Natal*, Vereda*, Fitó 1000 e Gold mine* \\
Pele de Sapo & C. melo var inodorus Naud & Sancho*, Medelin*, Meloso, Fitó 1500 e Daimiel \\
Honey Dew & C. melo var inodorus Naud & Orange County, Royal Sweet* e Athenas* \\
Gália & C. melo var cantalupensis Naud & Estoril*, Amaregal*, Mclaren*, Cyro* e Galileo \\
Cantaloupe & C. melo var cantalupensis Naud & Caribbean Gold*, Florentino*, Sedna e Torreon* \\
Charentais & C. melo var cantalupensis Naud & Concorde, Magrite*, Sunrise, Mehary e Apodi
\end{tabular}

Fonte: Aragão, 2011. / *Algumas das cultivares avaliadas neste trabalho.

\subsection{Características gerais}

O meloeiro é uma espécie, preferencialmente alógama, com taxa de alogamia de 5,4-73,2\%, que pode apresentar expressão sexual monóica, andromonóica, ginomonóica ou hermafrodita (COSTA \& PINTO, 1977; FERREIRA, 2006), rasteira e que possui ovário ínfero e fruto do tipo baga com cor e formato variável (COSTA et al., 2000). O grão de pólen é de natureza viscosa, necessitando de um agente polinizador para haver o transporte até a superfície estigmática (FILGUEIRA, 1972). O isolamento de melão dos insetos polinizadores tem provado que as flores hermafroditas são incapazes de realizar a autopolinização. O pólen deve ser transferido da antera para o estigma por insetos. A abelha melífera (Aphis melífera 
FACULDADE DE AGRONOMIA E MEDICINA VETERINÁRIA

Programa de Pós Graduação em Agronomia

L.) é o polinizador mais eficiente da cultura do melão, assegurando altos índices de produtividade (SOUSA et al., 2009).

É uma planta diploide com número básico de cromossomos igual a $12(2 \mathrm{x}=2 \mathrm{n}=24)$ e classifica-se botanicamente como uma olerícola, apesar de seus frutos serem consumidos como frutas (WANG et al., 1997).

Apresenta plantas anuais, herbáceas, de caule prostrado, sulcado, não aculeado com número de hastes ou ramificações variável e folhas alternadas simples (KIRKBRIDE, 1993). Possui sistema radicular ramificado, vigoroso e pouco profundo, concentrado nos primeiros 20 a 30 cm de solo (GÓMEZ-GUILLAMÓN et al., 1993; MATHEW et al., 1986). As flores masculinas são agrupadas em uma inflorescência tipo cacho enquanto as hermafroditas são solitárias (GÓMEZ-GUILLAMÓN et al., 1985).

Além do local, os fatores climáticos são indicadores importantes para a escolha da melhor época de plantio. Geralmente, o meloeiro se desenvolve bem em ambientes com alta temperatura $\left(25-35^{\circ} \mathrm{C}\right)$, alta luminosidade (2000-3000 hs/ano) e baixa umidade relativa (6575\%). Em solos férteis, de textura média e bem drenados, geralmente com irrigação por gotejamento, adubação e manejo em geral, de acordo com o recomendado para a cultura (COSTA et al., 2000).

As pragas e doenças da cultura são fatores muito relevantes e que interferem na produção e baixa qualidade do produto final, preocupando toda a cadeia produtiva, desde o agricultor até o consumidor. Entre as principais pragas do melão no Brasil estão a Mosca Branca (Bemisia argentifolii), Pulgão (Aphis gossypii), Mosca Minadora (Liriomyza sativaee Liriomyza huidobrensis), Tripes (Thrips palmi), Ácaros (Tetranychus urticae), Vaquinha (Diabrotica speciosa) e Broca das Cucurbitáceas (Diaphania nitidalis e Diaphania hyalinata L.). O controle químico é o mais efetivo e utilizado para essas pragas com produtos devidamente registrados pelo Ministério da Agricultura, Pecuária e Abastecimento (MAPA) (COSTA et al., 2000). 
FACULDADE DE AGRONOMIA E MEIDICINA VETERINÁRIA

Programa de Pós Graduação em Agronomia

Entre as principais doenças que comprometem a cultura do melão estão o Cancro das hastes (Didymella bryoniae), Podridão-do-colo (Macrophomina sp.), Oídio (Podosphaera xanthii; Oidium sp.), Míldio (Pseudoperonospora cubensis), Antracnose (Glomerella cingulata var. arbiculare; Colletotrichum lagenarium), Murcha de fusarium (Fusarium oxysporum), Mancha Bacteriana ou Catapora (Pseudomonasspp.), Nematóides (Meloidogyne spp.), Viroses (Watermelon mosaic vírus (WMV) 1 e 2, e Cucumber mosaic vírus (CMV). O controle mais efetivo para essas doenças ainda é o químico, também com produtos devidamente registrados pelo MAPA (COSTA et al., 2000).

A colheita é manual, evitando-se danos mecânicos, sendo que para comercialização em mercados locais, colhe-se o fruto completamente maduro, e para exportação, quando iniciam a mudança de coloração e apresentam em torno de $10^{\circ}$ brix. Vários outros indicadores de colheita são usados, dependendo da variedade, porém os principais são a mudança de coloração da casca e o brix, medido com refratômero de campo. Após a colheita, realiza-se o resfriamento do fruto e posterior beneficiamento e armazenagem em temperatura e umidade adequadas (COSTA et al., 2000).

2.5 Melhoramento genético do Melão

O melhoramento de plantas é a forma mais ecologicamente responsável de se aumentar a produção de alimentos com a adaptação da planta ao ambiente de cultivo, atendendo e proporcionando benefícios na alimentação humana e animal, na energia e em outras áreas de suma importância na sociedade. O melhoramento permite o desenvolvimento de cultivares resistentes ou tolerantes a pragas, doenças e a estresses climáticos, bem como cultivares mais produtivas e de melhor qualidade (BORÉM \& MIRANDA, 2013).

O melhoramento genético torna-se a principal ferramenta que contribui para manter ou aumentar os índices econômicos citados por meio do aumento da produtividade e melhoria de características ligadas a qualidade, como aumento de conservação pós colheita, a resistência a estresses bióticos e a pragas e doenças, e aumento do teor de sólidos solúveis (brix). 
FACULDADE DE AGRONOMIA E MEIDICINA VETERINÁRIA

Programa de Pós Graduação em Agronomia

Os programas de melhoramento genético das instituições públicas e das empresas de sementes têm sido dinamizadas, principalmente nos países exportadores, oferecendo frequentemente sementes de cultivares com fonte de resistência ou atributos qualitativos que atendam às exigências de produtores e consumidores locais (PAIVA, 1999).

Empresas espanholas, pública e privada, promoveram em parceria o sequenciamento do genoma do melão. A anotação do genoma montado previu 27.427 genes, um número semelhante ao de outras espécies de plantas. Um baixo número de genes de resistência a doenças foi anotado o que sugere a existência de mecanismos de defesa nesta espécie. Esse estudo permitirá avanços significativos no melhoramento genético ligado a características de resistência a pragas e doenças e ligados à qualidade, bem como na evolução e compreensão da variabilidade genética existente na espécie (GARCIA-MAS et al., 2012). Projetos genomas funcionais ("transcriptomas") de melão estão em andamento combinados com sistemas que permitem análise em larga-escala de padrões de expressão gênica (YARIV et al., 2002; PUIGDOMÉNECH et al., 2007). Com relação a transgenia, um dos objetivos recentes tem sido agregar a maior durabilidade pós-colheita em melão (NUÑES-PALENIUS et al., 2006).

O melão apresenta meiose regular e fertilidade de pólen superior a 90\% (LOPES et al., 1999). É uma espécie bastante polimórfica com grande variabilidade para o tamanho da planta (1-10 metros); peso de frutos ( $10 \mathrm{~g}$ até $10 \mathrm{Kg}$ ); teor de sólidos solúveis (entre 3 e 18\%) e acidez da polpa (pH variando de 3 a 7). Esta variação tem merecido e despertado o interesse de muitos pesquisadores (PAIVA, 1999).

Uma das formas de se aumentar a competitividade do produto brasileiro no mercado internacional e o consumo interno do fruto é por meio do melhoramento genético voltado para a melhoria de qualidade do fruto, especialmente do aumento do conteúdo e composição de açúcares, expresso como teor de sólido solúveis ( ${ }^{\circ}$ brix) da polpa do fruto e maior conservação pós-colheita (AROUCHA et al., 2009; MENEZES et al., 2001; DIAS, 1997). 
FACULDADE DE AGRONOMIA E MEIDICINA VETERINÁRIA

Programa de Pós Graduação em Agronomia

O brix (sólidos solúveis totais) é um dos atributos de qualidade que serve como auxílio para a classificação do melão de acordo com seu teor de açúcar (COSTA et al., 2000). Frutos com valores menores do que $9^{\circ}$ brix são considerados não comercializáveis; de 9 a $12^{\circ}$ brix, comercializáveis e acima de $12^{\circ}$ brix, melão extra (GORGATTI NETO et al. 1994).

Segundo Aragão (2011), o meloeiro é uma planta que pode ser considerada tanto de polinização cruzada quanto de autofecundação, ou seja, mista, podendo ser submetida a métodos de melhoramento apropriados para ambos os tipos de planta.

Os métodos que podem ser utilizados para o desenvolvimento de linhagens endogâmicas incluem o Método de Pedigree, "Single Seed Descent" (SSD) e o Teste de Gerações Iniciais de Endogamia ("early generation testing”), sendo o SSD a forma mais rápida e eficiente de geração de linhagens em processos de endogamia realizados fora da área ou da época de cultivo (FEHR, 1987). Se o objetivo do melhoramento de melão é a produção de híbridos e envolve, principalmente, caracteres associados tanto à natureza discreta quanto à contínua ou quantitativa, a seleção recorrente é uma alternativa apropriada (ARAGÃO, 2011).

As cultivares híbridas de melão têm tido a preferência dos produtores que utilizam níveis elevados de tecnologia devido às características superiores, como alta produtividade, resistências múltiplas às doenças mais importantes, além da uniformidade de colheita e qualidade dos frutos (CRISÓSTOMO, 2000).

A partir da década de 1980, assim como no resto do mundo, começou a utilização de híbridos simples $F_{1}$, que no caso do Brasil eram importados principalmente dos Estados Unidos, da Europa, de Israel e do Chile, com predominância dos tipos de melões Amarelos e em menor quantidade os tipos Pele de Sapo e Cantaloupe (ALVES et al., 2000).

Segundo Fosberg \& Smith (1980), o uso de sementes híbridas é restrito a espécies cujos aumentos nos custos de produção são suplantados pela superioridade dos híbridos em função do vigor híbrido e/ou uniformidade na qualidade, em relação às cultivares de polinização aberta. 
FACULDADE DE AGRONOMIA E MEIDICINA VETERINÁRIA

Programa de Pós Graduação em Agronomia

A perda de vigor em outras espécies vegetais foi associada com a presença de alelos deletérios e letais em genótipos homozigóticos. Muitos genes recessivos permanecem ocultos em condições heterozigotas nas populações naturais, à medida que a homozigose aumenta nas populações endogâmicas, existe a probabilidade maior para que as características recessivas, muitas das quais são deletérias, comecem a se manifestar, resultando em perda de vigor. Além da estrutura genética de C.melo L., que suporta autofecundações sucessivas sem perda de vigor por endogamia, a planta recupera certas características desejáveis (ALLARD, 1971; McCREIGHT et al., 1993).

A utilização de híbridos de melão é possível pela possibilidade de produção de sementes híbridas a um preço acessível e pela estratégia de controle de doenças importantes por meio da incorporação de alelos de resistência em pelo menos uma das linhagens parentais dos híbridos. Contudo, como o cultivo de melão apresenta forte influência das condições ambientais (ex. tipo de solo, temperaturas diurnas e noturnas, comprimento do dia, qualidade da água) e das práticas culturais (ex. data de plantio, níveis de fertilizante, irrigação, entre outros), os híbridos experimentais devem ser testados obrigatoriamente para produtividade e qualidade de frutos nas áreas de interesse, utilizando-se as práticas culturais usuais à cultura na região (McCREIGHT et al., 1993).

Tem-se observado que cultivares híbridas introduzidas em regiões onde as condições climáticas favorecem o cultivo da planta tem apresentado ciclo vegetativo encurtado, tornando-se muito precoces, o que aparentemente, pode ser vantajoso para o produtor, porém, tem tornado as plantas mais susceptíveis às doenças ocorrentes na região e perda de qualidade do fruto (PAIVA et al., 2002). As doenças e pragas são preocupantes para produtores, processadores, comerciantes e consumidores porque reduzem a produção e afetam qualidade do produto. A produtividade é comprometida caso ocorra incidência de viroses, pois o controle químico tem mostrado pouca eficiência. Entre as infecções virais que comprometem seriamente a qualidade e a quantidade produzida está o vírus-2 do mosaico da melancia (WMV-2), e o PRSV-w, que corresponde a nova designação para o vírus-1 do 
FACULDADE DE AGRONOMIA E MEIDICINA VETERINÁRIA Programa de Pós Graduação em Agronomia

mosaico da melancia (WMV-w) e constitui o vírus de maior importância econômica para a cultura do melão no nordeste brasileiro (LEWIS \& ZAYKIN, 1992; PAIVA et al., 2002).

No Brasil, pela peculiaridade da extensão territorial, o tipo de melão que mais se adaptou foi o do grupo Inodorus, denominado de valenciano ou amarelo. O fruto resiste bem ao transporte a grandes distâncias e mostra também longa vida de prateleira. Este tipo serviu de base para o lançamento de inúmeras variedades. Na década de 80, a Embrapa CNPH (Embrapa Hortaliças) desenvolveu pesquisas (Programa Nacional de Pesquisas de Hortaliças) para a incorporação de genes de resistência ao vírus PRSV-w estirpe w, no genoma da cultivar Amarelo valenciano, o que culminou, em 1987, com o lançamento da cultivar Eldorado-300, resistente ao PRSV-w e com características próximas ao valenciano (PESSOA et al. 1988; PAIVA, 1999; LOPES et al., 1999).

Outro fator preocupante dos cultivos comerciais, sobretudo no Nordeste brasileiro, é a influência do ambiente na produção. A maioria das variedades e híbridos cultivados foi desenvolvida para condições climáticas específicas, com resistência às doenças verificadas no local em que o melhoramento foi efetuado. No semiárido estas variedades são cultivadas em ambientes bastante diversos daqueles para onde foram selecionados. Esta condição de estresse a que são submetidos resulta em encurtamento do ciclo produtivo, redução da produção e perda de qualidade, principalmente no que concerne ao teor de sólidos solúveis (PAIVA, 1999).

As pesquisas com melhoramento genético do meloeiro no CNPAT (Embrapa Agroindústria Tropical) surgiram para atender uma necessidade dos produtores verificada em 1995 quando, através de um levantamento das dificuldades observadas pelos produtores do Vale do Assu, no Rio Grande do Norte (ALVES et al. 1995), ficou evidente a necessidade de sementes com melhor adaptação às condições nordestinas. Foi, então, proposto um trabalho para obter linhagens com resistência ao cancro da haste, sob a liderança do CPATSA (Embrapa Semiárido). Posteriormente, ampliou-se o raio de ação para a obtenção de híbridos com resistência as doenças e com qualidade de frutos (PAIVA, 1999). Infelizmente a maioria 
FACULDADE DE AGRONOMIA E MEDICINA VETERINÁRIA

Programa de Pós Graduação em Agronomia

das sementes utilizadas eram de cultivares de baixa aceitação comercial no mercado externo ou importadas, que ainda apresentam baixa adaptação a essas regiões (LOPES et al., 1999).

Em 1996 o projeto de melhoramento do meloeiro teve início no CNPAT com o resgate de sementes disponíveis nas unidades da EMBRAPA e no Instituto Nacional de Pesquisas da Amazônia - INPA, além de sementes comerciais. Alguns destes materiais já apresentavam fonte de resistência para algumas das doenças importantes para o cultivo de melão no Nordeste. Em 1997 foram incorporadas linhagens cedidas pela Dra. Molly Kill, da Universidade de Cornell. Este germoplasma está sendo utilizado na condução de dois programas de melhoramento: O primeiro a curto prazo, utilizará de sucessivas gerações de autofecundação, resultando em linhagens cuja maioria dos genes estarão em homozigose. $\mathrm{O}$ segundo programa, proposto por Costa \& Pinto (1977), a ser desenvolvido a médio e longo prazo, pretende ampliar a base genética do germoplasma nacional com novos acessos seguido da recombinação para sintetizar populações de melão dos tipos mais exigidos, as quais passarão por processo de seleção recorrente para posterior extração de linhagens. Dessa forma, os dois programas possibilitam a obtenção de híbridos que atendam às exigências do mercado interno e externo, adaptados à região Nordeste, com resistência a doenças causadas por fungos, bactérias e vírus, tolerância à mosca branca e que produzam frutos de qualidade comercial (PAIVA, 1999).

Devido à preferência do mercado nacional ser concentrada em um único tipo de fruto, o do tipo amarelo, a base genética do melão nacional é bastante estreita e as possibilidades de detecção de genótipos superiores se tornam reduzidas. Existe, portanto a necessidade da introdução de novos genes, principalmente para fonte de resistência às doenças mais importantes (PAIVA, 1999).

Os baixos níveis de $\beta$-caroteno e de Vitamina $\mathrm{C}$ no melão Amarelo quando comparado ao melão Cantaloupe podem ser incrementados por cruzamentos com esse, notadamente o tipo com maior valor nutricional haja vista que a herdabilidade para essas características são elevadas (PAIVA et al., 2002). 
FACULDADE DE AGRONOMIA E MEDICINA VETERINÁRIA

Programa de Pós Graduação em Agronomia

\subsection{Análise Molecular}

Marcadores genéticos são caracteres que possuem mecanismo de herança simples e podem ser utilizados para avaliar diferenças genéticas (polimorfismos) entre dois ou mais indivíduos. Podem ser marcadores morfológicos, que são baseados em fenótipos e geralmente de fácil identificação, ou moleculares, que são baseados em características genéticas e segundo Hoffmann \& Barroso (2006), consistem em pequenos fragmentos de DNA obtidos por meio de ferramentas da Biotecnologia moderna, e ambos auxiliam em uma série de estudos genéticos vegetais e animais.

Marcador molecular é todo e qualquer fenótipo molecular oriundo de um gene expresso (como em izoenzimas) ou de um segmento específico de DNA (expresso ou não) (FERREIRA \& GRATTAPAGLIA, 1998).

Entre as vantagens do uso de marcadores moleculares pode-se citar a identificação direta do genótipo sem a influência do ambiente, a possibilidade de detecção de polimorfismos em qualquer estádio de desenvolvimento da planta ou a partir de cultura de células ou tecidos. Com o advento das tecnologias modernas de Genética e da biologia molecular, surgiram diversos tipos de marcadores moleculares que detectam o polimorfismo genético diretamente no DNA (FALEIRO, 2007).

As metodologias para detectar e analisar a variabilidade genética a nível molecular oferecem informações adicionais a diversos outros estudos relacionados à conservação e uso de bancos de germoplasma, estudos filogenéticos, mapeamento genético, mas a principal aplicação do estudo da genética de plantas é o melhoramento genético (HOFFMANN \& BARROSO, 2006).

A maior vantagem dos métodos moleculares é a investigação direta genotípica que permite a detecção de variação ao nível de DNA excluindo, portanto, influências ambientais. Dependendo da metodologia escolhida, os métodos moleculares podem detectar mais diversidade genética do que os métodos clássicos de caracterização morfológica (BUSO, 2005). Apesar de fornecer dados de interesse detalhados, as tecnologias e metodologias 
FACULDADE DE AGRONOMIA E MEDICINA VETERINÁRIA

Programa de Pós Graduação em Agronomia

envolvidas na obtenção e análise dos diversos marcadores genéticos, sobretudo moleculares, implicam em questões financeiras relacionadas à infraestrutura e recursos humanos com treinamento. Além desses fatores, a decisão de qual tipo de marcador usar, depende principalmente do objetivo do estudo.

Os marcadores moleculares diferem-se com relação à características importantes, como abundância genômica, nível de polimorfismo detectado e informação genética, especificidade dos locos, reprodutibilidade, dominância, requerimentos técnicos para revelação dos polimorfismos e investimentos financeiros (BUSO, 2003).

A abundância genômica diz respeito à cobertura de marcadores no DNA, ou seja, a sua ocorrência no mesmo. Segundo Hoffmann \& Barroso (2006), RAPD e microssatélites têm melhor distribuição no genoma que isoenzimas, mas quaisquer destes são muito mais frequentes e dispersos do que os marcadores morfológicos. O nível de polimorfismo detectado depende da base genética do marcador e da informação genética que essa base carrega consigo. Com relação à especificidade dos locos, os marcadores podem ser multilocos, obtidos de múltiplas regiões gênicas (RAPD, AFLP), ou uniloco, que fornecem dados de um único loco (FALEIRO, 2007).

Quanto à reprodutibilidade do marcador, significa dizer que, um marcador para uma determinada população e em determinada condição, necessariamente se apresentará da mesma forma se reproduzido em outro laboratório, ou seja, quanto maior a reprodutibilidade, mais confiável será o marcador em questão.

Quanto à dominância, marcadores moleculares podem ser classificados em dominantes ou codominantes. Marcadores dominantes, não diferem genótipos homozigotos de heterozigotos, como é o caso de RAPD, AFLP, ISSR, entre outros. Já os marcadores codominantes, conseguem distinguir esses genótipos, e dessa forma se tornam mais informativos, como é o caso do RFLP, SSR e marcadores izoenzimáticos (baseados na expressão proteica) (ZUCCHI et al., 2011). A dominância pode restringir a possibilidade de sua utilização em análises genéticas onde seja importante diferenciar homozigotos de 
FACULDADE DE AGRONOMIA E MEIDICINA VETERINÁRIA

Programa de Pós Graduação em Agronomia

heterozigotos. Isto será particularmente importante em populações de plantas alógamas, onde a porcentagem de locos em heterozigose é alta (HOFFMAN \& BARROSO, 2006).

$\mathrm{O}$ uso de marcadores moleculares envolve recursos financeiros e investimentos em infraestruturas e mão de obra com treinamento que possam operar equipamentos específicos e delicados como termocicladores, aparelhos de eletroforese, centrífugas, dentre outros, e que saibam manusear reagentes necessários para elaboração de PCR.

Marcadores ligados ao gene de interesse podem servir para seleção indireta de indivíduos no melhoramento de plantas. Este processo chama-se seleção assistida por marcadores (SAM). A seleção assistida é particularmente importante quando realizada para caracteres que se expressam em estágios de desenvolvimento avançado, como características de frutos e sementes, quando o padrão de herança é recessivo ou quando há necessidade e operações especiais para que o gene se expresse, como para resistência à pragas e doenças. (HOFFMANN \& BARROSO, 2006).

Estimativas de divergência genética entre linhagens por meio de marcadores moleculares contribuem para poupar esforços de polinizações manuais já que, não dependem do estágio fenológico da planta, não sofrem influência ambiental e podem ser aplicadas a muitos acessos, direcionando os cruzamentos na tentativa de se obter híbridos mais vigorosos (LABORDA et al., 2005; JOSÉ et al., 2005). Melões silvestres e cultivados de distintas origens geográficas têm sido descritos e alto nível de variabilidade morfológica em caracteres de folhas plantas e frutos tem sido mostrado dentro desta espécie (PITRAT et al., 2000). Com base nesta variação, pesquisadores têm identificado cruzamentos divergentes e obtido populações segregantes com alta variabilidade, por meio da realização de estudos de divergência genética (CHUNG et al., 2006; STAUB et al., 2004). Estudos de divergência também auxiliam os melhoristas na tomada de decisão sobre quais cruzamentos entre linhagens podem gerar os melhores híbridos (OLIVEIRA et al., 1996).

Segundo Barbieri et al., (2005), quanto mais divergentes forem os genitores maior a variabilidade resultante na população segregante, e maior a probabilidade de reagrupar os 
FACULDADE DE AGRONOMIA E MEIDICINA VETERINÁRIA

Programa de Pós Graduação em Agronomia

alelos em novas combinações favoráveis. A divergência genética tem importância no melhoramento, pois quando bem explorada, pode reduzir a vulnerabilidade da cultura a doenças e acelerar o progresso genético de determinadas características (CUI et al., 2001). No Brasil, técnicas multivariadas tem sido empregadas na seleção de caracteres e na quantificação da diversidade de espécies de cucurbitáceas, como abóbora (AMARAL JUNIOR et al.,1996), melancia (SILVA, 2007), e melão (TORRES FILHO, 2008).

Após coletado, o germoplasma é anexado a um banco ativo de germoplasma (BAG) no qual passará por outras atividades, que são: documentação, caracterização, avaliação e conservação (RAMOS et al., 2007; VALLS, 1988; HAWKES, 1982). Vale ressaltar que a utilização da divergência genética disponível nas coleções de trabalho e bancos de germoplasma, que se configura como a matéria prima do melhoramento genético vegetal, depende da caracterização e documentação dos genótipos de forma que o melhoramento possa identificar a potencialidade de uso dessas constituições genéticas (BORÉM, 1997).

Existem BAG's de melão em diferentes países com destaque para a Rússia (>2900 acessos), EUA (>2300 acessos), França (>1800 acessos) e China (>1200 acessos) (MLIKI et $a l .$, 2001). Espécies de melões silvestre e cultivados de distintas regiões geográficas e com alto nível de variabilidade morfológica, tem sido descritos (PITRAT et al., 2000). Escribano \& Lázaro (2009) encontraram grande variabilidade em uma pequena região, mas com enorme importância histórica na produção de melão na Espanha. No Brasil, algumas instituições dispõem de coleções ou BAG, com destaque para o BAG de melão da Embrapa Hortaliças, com cerca de 400 acessos e a coleção de germoplasma de melão da Embrapa Semi-Árido, com 150 acessos (SILVA et al., 2001). Entretanto, as provisões da Convenção da Diversidade Biológica têm incentivado legislações nacionais de afirmação da soberania sobre os recursos genéticos, o que dificulta o fluxo desses recursos em âmbito internacional (QUEIROZ \& LOPES, 2007).

A heterose ou vigor híbrido é um termo empregado no melhoramento de plantas para descrever a superioridade de uma combinação híbrida em relação à média de seus genitores (BOS \& CALIGARI, 1995). Paiva et al., (2002) estudaram a relação da divergência 
FACULDADE DE AGRONOMIA E MEDICINA VETERINÁRIA

Programa de Pós Graduação em Agronomia

genética entre linhagens de melão e a heterose de seus híbridos e encontrou correlações significativas para produção por planta e diâmetro da cavidade interna. Entretanto, as linhagens com pequenas distâncias apresentaram híbridos com efeitos heteróticos, o que mostrou que o cruzamento entre linhagens divergentes não será necessariamente, garantia de heterose.

Avaliando linhagens de vários tipos de melão, Paiva (2002) observou heteroses positivas para a produtividade, teor de sólidos solúveis e outras características do fruto e da planta. É importante observar que a heterose negativa (menor desempenho do que a média de seus genitores) nem sempre é ruim, haja vista que o melhorista pode ter interesse em reduzir a característica em questão (CRUZ \& REGAZZI, 1997), como por exemplo, a espessura da cavidade interna do fruto (ARAGÃO, 2011).

O uso de marcadores moleculares tem sido uma importante ferramenta na investigação das linhagens melhoradas, mesmo dentro de grupos botânicos, pois detecta divergência genética suficiente para produzir híbridos com significativos efeitos heteróticos (DELEU et al., 2009; JOSÉ et al., 2005; STAUB et al., 2004). Segundo Garcia et al., (1998), marcadores moleculares foram mais eficientes do que as características agronômicas na predição da distância genética entre linhas melhoradas e do comportamento de alguns híbridos. O uso de métodos altamente discriminatórios para a identificação e caracterização de genótipos é essencial para programas de melhoramento e até para a proteção de cultivares (REZENDE et al., 2009).

Tradicionalmente, descritores morfológicos associados a aspectos agronômicos têm sido eficientes em muitos estudos de avaliação de germoplasma, entretanto, com o advento de novas técnicas inovadoras e específicas baseadas na sequência de DNA, os estudos moleculares auxiliam frequentemente os melhoristas convencionais, associando informações de grande importância para conservação e manutenção da variabilidade genética. QUEIROZ (2004) afirmou que no Brasil, é necessário ampliar a avaliação da variabilidade existente e examinar a necessidade de novas coletas para se obter germoplasma de cucurbitáceas para conservação de longo prazo e para uso em programas de melhoramento. 
FACULDADE DE AGRONOMIA E MEDICINA VETERINÁRIA

Programa de Pós Graduação em Agronomia

Muitos procedimentos em biologia molecular baseiam-se em reações de PCR (Polymerase Chain Reaction) ou reação em cadeia da polimerase (FERREIRA \& GRATTAPAGLIA, 1998).

\subsection{PCR}

A PCR é um método de amplificação (criação de inúmeras cópias) de DNA in vitro. Essa técnica foi inventada pelo bioquímico Kary Banks Mullis em 1983 e trata-se de um marco importantíssimo nos estudos moleculares. Nessa mesma década, desenvolveram-se algumas técnicas, uma delas a duplicação do DNA, in vitro, realizada pela DNA polimerase extraída da bactéria Thermus aquaticus, que, por viver em fontes térmicas, possui enzima que polimeriza a uma temperatura alta $\left(72^{\circ} \mathrm{C}\right)$ e mantém atividade mesmo que submetida a $95^{\circ} \mathrm{C}$ (SAIKI et al., 1988). Isto é importante para a automação do processo in vitro, onde a alta temperatura é utilizada como estratégia para separar as fitas de DNA, necessária para o processo de duplicação (FERREIRA \& GRATTAPAGLIA, 1998).

Em resumo, a PCR é a síntese enzimática in vitro de milhões de "cópias" de um segmento específico de DNA, na presença da enzima DNA polimerase a partir de uma sequência alvo. (BUSO et al., 2009).

Uma reação de PCR envolve uma quantidade mínima de DNA (da ordem de alguns nanogramas), um par de oligonucleotídeos (pequenas moléculas de DNA de fita simples) utilizados como iniciadores da reação, chamados de primers, que delimitam a sequência alvo da amplificação, e um mix de reagentes essenciais para que a reação ocorra.

Um ciclo de PCR envolve 3 etapas (BUSO et al., 2009):

- Desnaturação: Nessa etapa, a fita dupla do DNA é desnaturada (separada) por elevação de temperatura $\left(92-95^{\circ} \mathrm{C}\right)$; 
FACULDADE DE AGRONOMIA E MEDICINA VETERINÁRIA

Programa de Pós Graduação em Agronomia

- Anelamento: Na etapa de anelamento, a temperatura é rapidamente reduzida $\left(35-60^{\circ} \mathrm{C}\right)$, dependendo do tamanho e sequência do primer utilizado (otimizada para cada primer). Essa condição permite que o anelamento do primer ocorra nas sequências complementares que flanqueiam a região alvo.

- Extensão: Nessa etapa, a temperatura é elevada para $72^{\circ} \mathrm{C}$ para que a enzima DNA polimerase realize a extensão. Uma vez que a quantidade de DNA dobra a cada ciclo, a amplificação segue uma progressão geométrica de maneira que, após 20 ciclos, são produzidos mais de um milhão de vezes a quantidade inicial da sequência alvo.

Essa escala de amplificação permite, portanto, iniciar a reação com quantidades mínimas de DNA e terminar com grandes quantidades de uma sequência específica de interesse (ANTONINI et al., 2004).

Entretanto, a elaboração de primers para amplificação via PCR depende do conhecimento prévio das sequências de nucleotídeos que flanqueiam a sequência de DNA de interesse. Para se conhecer estas sequências é necessária a clonagem e sequenciamento da região. Atualmente, alguns marcadores são baseados em primers com sequências aleatórias, o que popularizou as análises genéticas, pois, nesses casos, não é necessário conhecer previamente as sequências das espécies alvos dos estudos genéticos (BUSO et al., 2009).

O desenvolvimento de primers específicos não restringe necessariamente, o uso à espécie em questão, já que pode haver transferibilidade de primers de uma espécie para outra do mesmo gênero. Maia et al., (2013), estudaram a transferibilidade de 30 primers microssatélites de melão para melancia, e obteve $77 \%$ de transferibilidade dos mesmos, que podem ser utilizados como ferramentas de auxílio em programas de melhoramento para a melancia.

O mix de reagentes envolve os seguintes componentes (BUSO et al., 2009): 
FACULDADE DE AGRONOMIA E MEDICINA VETERINÁRIA

Programa de Pós Graduação em Agronomia

- Água: A água usada para reações de PCR, diluições de primers e de DNA, deve ser filtrada em aparelho Mili-Q e renovada semanalmente, pois a qualidade da mesma pode influenciar na PCR;

- Tampão 10x: Oferece as condições básicas para que a reação ocorra;

- dNTP: São desoxinucleotídeos trifosfato livres, utilizados como percussores da síntese de DNA;

- BSA: Bovine Serum Albumin que servem para estabilizar a ação da taq ou DNA polimerase;

- $\mathrm{MgCl}_{2}$ : Serve como cofator da enzima taq polimerase;

- Taq DNA polimerase: Enzima que sintetiza o DNA, responsável pela fase de extensão da PCR.

2.8 Tipos de marcadores moleculares

Os principais tipos de marcadores moleculares podem ser classificados em dois grupos, conforme a metodologia usada para identifica-los: Hibridização ou amplificação de DNA. Entre os identificados por hibridização estão os marcadores RFLP; Minissatélites ou VNTR, obtidos com o uso de enzimas de restrição, e amplificados por meio de sondas. Já aqueles revelados por amplificação incluem o RAPD; Microssatélites ou SSR; ISSR; AFLP e SNP, (MILLACH, 1999), geralmente, amplificados via PCR.

- Marcadores por hibridação

\section{RFLP (Restriction Fragment Length Polymorphism)}


FACULDADE DE AGRONOMIA E MEDICINA VETERINÁRIA

Programa de Pós Graduação em Agronomia

Os RFLPs ou polimorfismos no comprimento de fragmentos de restrição, são pequenos fragmentos de DNA obtidos com uso de enzimas de restrição. A visualização de polimorfismos é realizada após a transferência dos fragmentos para uma membrana de nylon e hibridização com sondas de sequências homólogas marcadas com radioatividade ou fluorescência. Esse tipo de marcador pode ser obtido de genes de diferentes regiões, como o DNA de ribossomo, mitocôndria ou de cloroplasto (AVISE, 1993; FALEIRO, 2007).

A codominância e alta reprodutibilidade são as principais vantagens do uso desse marcador. As desvantagens incluem a grande quantidade e qualidade de DNA a ser analisado; a necessidade de sondas específicas para hibridização; a baixa proporção de locos polimórficos; e o fato de ser uma técnica mais trabalhosa demorada e onerosa. Esse tipo de marcador detecta variações em sequências de DNA de 4-8 pb. O número médio de alelos identificados por loco varia de acordo com a estrutura genômica da espécie estudada, mas não é tão alto como SSR (FERREIRA \& GRATTAPAGLIA, 1998; NEALE \& WILLIAMS, 1991; LOPES et al., 2002).

\section{Minissatélites ou VNTR (Variable Number of Tandem Repeats)}

Os marcadores Minissatélites ou número variável de repetições seriadas são unidades de 10 a 100 pb repetidas em tandem. Os microssatélites apresentam sequências mais curtas que os minissatélites. A obtenção desses marcadores inclui a extração e digestão do DNA com endonucleases de restrição seguido da transferência dos fragmentos obtidos para uma membrana de nylon e posterior hibridização dos mesmos com sondas de minissatélites marcadas para visualização dos polimorfismos existentes que se dá geralmente via auto radiografia. As principais vantagens do uso desse tipo de marcador são a alta reprodutibilidade das marcas e a geração de bandas muito informativas. As desvantagens são relacionadas à dominância dos marcadores (no caso de sondas para vários locos) e ao fato de a técnica ser mais onerosa, demorada e cara (FALEIRO, 2007). O procedimento de obtenção e detecção desse tipo de marcador é essencialmente o mesmo utilizado para RFLP (FERREIRA \& GRATTAPAGLIA, 1998). 
FACULDADE DE AGRONOMIA E MEDICINA VETERINÁRIA

Programa de Pós Graduação em Agronomia

- Marcadores por amplificação

\section{RAPD (Random Amplified Polymorphic DNA)}

Os marcadores RAPD ou polimorfismo de DNA amplificado ao acaso, se baseiam na amplificação simultânea de vários locos anônimos no genoma utilizando primers de sequência arbitrária. Essa técnica foi desenvolvida independentemente por dois grupos nos Estados Unidos. WILLIAMS et al., (1990) patentearam a tecnologia com o nome mais comumente utilizado, RAPD. Welsh \& McClelland (1990), por sua vez, propuseram o nome AP-PCR (Arbitrarily Primed-Polymerase Chain Reaction), uma vez que os primers possuem sequência arbitrária, mas a amplificação tecnicamente não ocorre ao acaso e sim em lugares específicos no genoma. Esse último grupo realizou o experimento com base na geração de “fingerprints" (impressões digitais) genômicos simples e reproduzíveis para a identificação de linhagens, utilizando eletroforese em poliacrilamida com primers um pouco mais longos. $\mathrm{O}$ polimorfismo é detectado pela presença ou ausência de bandas no gel (BUSO et al., 2009). Os fragmentos amplificados são separados em gel de poliacrilamida ou agarose, e visualizados após coloração com nitrato de prata ou brometo de etídeo sob luz UV (OFFEI et al., 2004).

RAPDs são utilizados principalmente apara análise de diversidade genética, identificação de cultivares, construção de mapas de ligação, mapeamento de QTL's e seleção assistida por marcadores (FALEIRO, 2007).

O que diferencia a reação de PCR para obtenção de marcadores RAPD de outras reações PCR é o tamanho do primer. No RAPD os primers são curtos, geralmente compostos por 10 nucleotídeos. Esse tipo de marcador apresenta algumas vantagens em relação a outros marcadores: um mesmo conjunto de primers pode ser usado em qualquer espécie uma vez que não se faz necessário o conhecimento prévio de dados de sequência de DNA para a construção dos primers utilizados; permite analisar um maior número de amostras por unidade de tempo (facilidade e rapidez); o investimento na instalação do laboratório e o custo por amostra são menores; As principais limitações do uso de RAPDs são: a sua dominância, classificado como marcador dominante, não diferencia indivíduos homozigotos de 
FACULDADE DE AGRONOMIA E MEDICINA VETERINÁRIA

Programa de Pós Graduação em Agronomia

heterozigotos onde apenas um único alelo é amplificado por loco, e sua baixa reprodutibilidade devido à sensibilidade da técnica às condições experimentais (HOFFMANN \& BARROSO, 2006; FERREIRA \& GRATTAPAGLIA, 1998).

Marcadores RAPD foram utilizados em melão por Katzir et al., (1996) e Garcia et al., (1998), proporcionando a detecção de polimorfismo entre tipos diferentes de melões e, até mesmo, entre linhagens proximamente relacionadas dentro do mesmo tipo. Além disso, Garcia et al. (1998) utilizaram RAPD também para verificar a correlação entre divergência genética e heterose. Neste caso, verificou-se que cruzamentos tanto entre linhagens de Gália quanto de Pele de Sapo produziram excelentes híbridos, os quais hoje já estão no mercado.

Buso et al., (2001a) analisaram a variabilidade genética de acessos de uma coleção de germoplasma de melão utilizando RAPDs e Gontijo et al., (2006), identificaram acessos e linhagens com alta divergência e promissores para o programa de melhoramento, analisando cerca de 200 acessos do BAG de melão da Embrapa Hortaliças também utilizando RAPDs.

\section{AFLP (Amplified Fragment Length Polymorphism)}

Esse tipo de marcador combina os princípios do RAPD e RFLP. São fragmentos de DNA de 80 a 500 pb obtidos com a digestão do DNA com enzimas de restrição, que clivam o DNA em sítios específicos, e é fundamental que essa digestão seja completa, pois a digestão parcial pode revelar falsos polimorfismos. Após a digestão, ocorre a ligação de primers adaptadores e amplificação seletiva dos fragmentos via PCR (FALEIRO, 2007; LOPES et al., 2002).

As vantagens do uso de AFLPs incluem a geração de grande número de polimorfismos por reação e o fato de não haver necessidade do conhecimento de sequência de DNA para desenvolvimento de primers. Gera uma grande quantidade de fragmentos, sendo muito informativo. Já as desvantagens se encontram nos altos custos e várias etapas e reagentes necessários para a obtenção desse tipo de marcador e também à dominância do 
FACULDADE DE AGRONOMIA E MEDICINA VETERINÁRIA

Programa de Pós Graduação em Agronomia

mesmo (FALEIRO, 2007; FERREIRA \& GRATTAPAGLIA, 1998), além do baixo conteúdo de informação genética por loco.

Teixeira (2004) identificou o marcador EK190 do tipo AFLP ligado ao gene Prv1, gene de resistência ao PRSV-W (Papaya ringspot virus - estirpe melancia), vírus muito importante na cultura do melão. Esse estudo pode auxiliar trabalhos futuros que façam uso de seleção assistida por marcadores moleculares.

Garcia-Mas et al. (2000) realizaram um estudo comparativo com os marcadores RAPD, AFLP e RFLP na análise da diversidade genética do melão e verificaram que o AFLP mostrou-se o marcador mais eficiente na detecção de polimorfismos dentre os 3 marcadores.

\section{SSR (Simple Sequence Repeats)}

As Sequências simples repetitivas ou microssatélites são sequências muito curtas, de 1-6 pb que podem estar repetidas em tandem, ou seja, uma após a outra (FALEIRO, 2007) flanqueadas por sequências únicas (MILLACH, 1999). Esse tipo de marcador revela polimorfismo em um loco devido a diferença no número de vezes em que um nucleotídeo se repete naquele loco (BUSO, 2003).

Os primers utilizados para a amplificação via PCR são específicos, e se anelam nas regiões que flanqueiam os microssatélites, geralmente com tamanho entre 20 e $30 \mathrm{pb}$, número suficientemente grande para que este primer não encontre outra sequência complementar que não a do microssatélite, o que restringe o uso à espécie em estudo. Nesse sentido é necessário primeiramente o desenvolvimento dos primers para a espécie por meio da construção de bibliotecas genômicas, seleção de clones positivos utilizando-se como sondas sequências repetitivas, e posterior sequenciamento para finalmente desenhar os primers, que em alguns casos, poderão ser usados em espécies geneticamente relacionadas (FALEIRO et al., 2003; HOFFMANN \& BARROSO, 2006). Deve-se ainda observar entre os possíveis primers, utilizando-se programas computacionais, a presença de grampos (anelamento do primer com ele mesmo) e dímeros (anelamento de dois primers) (HOFFMANN \& 
FACULDADE DE AGRONOMIA E MEDICINA VETERINÁRIA Programa de Pós Graduação em Agronomia

BARROSO, 2006). A temperatura de anelamento dos primers microssatélites deve ser otimizada afim de melhorar a especificidade do primer e obter amplificações nítidas. O uso de termocicladores com gradiente de temperatura, facilita a otimização (BUSO et al., 2009). O Laboratório de Genética Vegetal da EMBRAPA CENARGEN (Recursos Genético e Biotecnologia), desenvolveu primers SSR para várias espécies, como o eucalipto (BRONDANI et al., 1998), pequi (COLLEVATI et al., 1999), pimentas e pimentões (BUSO et al., 2000), feijão (BUSO et al., 2001b), arroz (BRONDANI et al., 2001), melão (RITSCHEL et al., 2004), dentre outras espécies de importância econômica. Após a otimização, a amplificação pode ser visualizada em gel de agarose 3,5\% ou em gel de poliacrilamida $5 \%$, com coloração com nitrato de prata $\left(\mathrm{AgNO}_{3}\right)$ e revelação com carbonato de sódio anidro $\left(\mathrm{Na}_{2} \mathrm{CO}_{3}\right)$ (BASSAM et al., 1991; CRESTE et al., 2001).

A principal vantagem do uso de microssatélites se encontra no fato de ser um marcador codominante que gera grande riqueza de informação genética, com alto nível de polimorfismo e reprodutibilidade além da possibilidade de detecção de vários marcadores no mesmo gel (multiplex) sendo mais rápido e eficiente quando comparado a outros tipos de marcadores (FALEIRO, 2007; ARAGÃO, 2011). Estes marcadores são abundantes e uniformemente distribuídos pelo genoma de eucariotos, podem ser multialélicos e apresentam alta heterozigosidade. Sua aplicação tornou um marcador de excelência na última década (KALIA et al., 2011; ZANE et al., 2002).

As principais desvantagens incluem o alto custo requerido do desenvolvimento de primers e a especificidade estreita dos mesmos, além da intensiva mão de obra para desenvolve-los (BUSO, 2003).

A caracterização molecular por meio do uso de marcadores microssatélites tem sido a técnica mais utilizada em estudos de divergência genética de melão, na última década (FUKINO et al., 2008; SZABÓ et al., 2005; GARCIA-MAS et al., 2004; DANIN-POLEG et al., 2001). Em um dos trabalhos pioneiros, Katzir et al., (1996) desenvolveram cinco primers SSR para melão, dos quais quatro deles detectaram polimorfismo entre diferentes grupos de melão (Reticulatus, Inodorus, Conomon e Acidulus). Mais recentemente, Ohse (2005) 
FACULDADE DE AGRONOMIA E MEDICINA VETERINÁRIA

Programa de Pós Graduação em Agronomia

mostrou que sequências repetitivas TC/AG são frequentes no genoma do melão e desenvolveu 107 pares de primers SSR para a espécie. Ritschel et al. (2004) também desenvolveram mais de 250 primers SSR para melão.

Gallego et al., (2005) realizaram estudo comparativo utilizando marcadores RAPD, AFLP e SSR na análise de diversidade genética do melão e verificaram que, em relação à detecção da presença ou ausência de fragmentos amplificados, os AFLPs e os SSRs são similares e melhores do que os RADPs, mas em relação à quantidade de informação genética, os microssatélites são incrivelmente superiores.

\section{ISSR (Inter Simple Sequence Repeats)}

São fragmentos de DNA de 100 a 3000 pb onde o procedimento de obtenção é um método baseado em microssatélite. O primer,composto por uma sequência do microssatélite usualmente de 16-25bp de comprimento, é utilizado para amplificar principalmente as sequências Inter-SSR de diferentes tamanhos (FALEIRO, 2007).

Os alelos polimórficos ocorrem sempre que em um genoma esteja faltando à sequência repetida ou têm uma deleção ou uma inserção que modifica a distância entre as repetições (COSTA, 2010).

De forma geral, os marcadores como ISSR são amplamente usados em estudos de diversidade genética, com as vantagens de que os procedimentos laboratoriais podem ser facilmente aplicados a várias espécies vegetais (COSTA, 2010), além de apresentar grande número de bandas informativas e o fato de não haver necessidade de conhecimento prévio da sequência de DNA para desenvolvimento de primers (FALEIRO, 2007). A principal desvantagem se encontra no fato de que os marcadores ISSR são dominantes.

Sestili et al., (2008) utilizaram marcadores ISSR para analisar a diversidade de 13 acessos de melão do grupo Inodorus oriundos de diferentes regiões geográficas da Itália e verificou 358 bandas polimórficas. Silva et al. (2012) utilizaram marcadores ISSR para estudo 
FACULDADE DE AGRONOMIA E MEIDICINA VETERINÁRIA

Programa de Pós Graduação em Agronomia

de caracterização de 20 acessos de melancia e um de melão do Banco Ativo de Germoplasma (BAG) de Cucurbitáceas para o Nordeste Brasileiro da Embrapa Semiárido e obtiveram 130 bandas polimórficas que geraram 3 grupos distintos, dois de melancia e um composto pelo único acesso de melão estudado.

\section{SNP (Single Nucleotide Polymorphism)}

Os SNPs ou Polimorfismos de Nucleotídeos Únicos são marcadores moleculares do DNA utilizados para identificar mutações geradas por polimorfismos baseados na posição de um único nucleotídeo (CHO et al., 1999). Os SNPs são a mais frequente forma de variação genética sendo gerados por substituição de uma única base ou pequenos eventos de inserção e deleção. Essas alterações pontuais podem ocorrer em regiões expressas ou não expressas, ou seja, a alteração de um único nucleotídeo, pode levar à formação de um aminoácido ou de uma proteína diferente. Os SNPs são muito utilizados em estudos filogenéticos de evolução intraespecífica (WOLTERS et al., 2000), mapeamento genético e principalmente na diferenciação de alelos do mesmo gene (MELLOTO \& KELLY, 2001; QUIRINO, 2003). Aproximadamente $90 \%$ da heterozigose na população humana é devida a SNPs (GOLDMAN et al., 2005). Muitos SNPs são denominados silenciosos porque resultam em substituições sinônimas de códons (trinca de bases), ou seja, que vão codificar o mesmo aminoácido independente do SNP (KIMCHI-SARFATY et al., 2007).

As etapas de obtenção desses marcadores envolvem o conhecimento prévio de sequência do gene de interesse para o desenho de primers e sondas específicas. Normalmente, com tais informações, são feitas etapas de amplificação, clonagem, e sequenciamento dos fragmentos do gene de interesse em diferentes indivíduos e as sequências obtidas são analisadas considerando-se os SNPs (FALEIRO, 2007).

Os SNPs apresentam a vantagem de detecção de grande quantidade de polimorfismos entre alelos de determinado gene e são abundantes no genoma de plantas e a principal desvantagem é a necessidade de conhecimento prévio da sequência do gene de 
FACULDADE DE AGRONOMIA E MEDICINA VETERINÁRIA

Programa de Pós Graduação em Agronomia

interesse e o custo/infraestrutura da técnica envolvida nas etapas necessária ao sequenciamento dos diferentes fragmentos do DNA de interesse (FALEIRO, 2007).

Nunes (2014) utilizou SNPs para identificar marcadores associados à resistência de oídio (Podosphaera xanthii) em acessos de melão. Esteras et al., (2013), validaram 768 SNPs para o melão utilizando 74 acessos pertencentes a maioria dos grupos botânicos existentes para a espécie. 
FACULDADE DE AGRONOMIA E MEDICINA VETERINÁRIA

Programa de Pós Graduação em Agronomia

\section{REFERÊNCIAS BIBLIOGRÁFICAS}

ALLARD, R.W. Princípios do melhoramento genético das plantas. São Paulo: Edgard Blucher, 1971. $381 \mathrm{p}$.

ALMEIDA, D. Manual de Culturas Hortícolas Volume II, 2006, 326p.

ALVES, R.S; SANTOS, F.J.S.; OLIVEIRA, V.H.de; BRAGA SOBRINHO, R.; CRISÓSTOMO, J.R; SILVA NETO, R, M. da; FREIRE, E.R; FROTA, P.C.E. Infraestrutura básica, situação atual, necessidades de pesquisa agrícola e capacitação de mão-de-obra no vale do Assu. Fortaleza: EMBRAPACNPAT, 1995. 25p.

ALVES, R.E.; PIMENTEL, C.R.; MAIA, C.E.; CASTRO, E.B.; VIANA, F.M.; COSTA, F.V.; ANDRADE, G.G.; FILGUEIRAS, H.A.C.; ALMEIDA, J.H.S.; MENEZES, J.B.; COSTA, J.G.; PEREIRA, L.S.E. Manual de melão para exportação. Brasília, EMBRAPA. 2000. 51p.

AMARAL JUNIOR, A.T.; CASALI, V.W.; CRUZ, C.D.; FINGER, F.L. Divergência genética entre acessos de moranga do banco de germoplasma de hortaliças da Universidade Federal de Viçosa. Horticultura Brasileira, v.14, n.2, p. 182-184, 1996.

ANTONINI, S.; CECCATO, R.; MENEGHIN, S.P.; URASHIMA, A.S. Técnicas Básicas de Biologia Molecular. Curso de extensão universitária "Técnicas básicas de biologia molecular" 12 a 16 de julho de 2004, no Laboratório de Microbiologia Agrícola e Molecular, Depto. Biotecnologia Vegetal/ Universidade Federal de São Carlos (UFSCar).

ARAGÃO de, F.A.S. Divergência genética de acessos e interação genótipo x ambiente de famílias de meloeiro. 2011. 137 f. Tese (Doutorado em Agronomia: Melhoramento Genético Vegetal). Universidade Federal Rural do Semi-Árido, Mossoró, 2011.

APEX BRASIL. Perfil exportador de melões brasileiros. Brasília: Agência Brasileira de Promoção de Exportações e Investimentos, 2014. 49p.

AROUCHA, E.M.M.; NUNES, G.H.S.; SOUSA, A.E.D.; FERNANDES, P.L.O.; SOUZA, M.S. Qualidade e potencial pós colheita de híbridos de melão. Revista Ceres, v.56, n.2, p.181-185, 2009.

ASHIZAWA, M.; YAMATO, S. Soviet melon. Agric. Hortic., v.40, p. 1355-1361, 1965.

AVISE, J.C.; Molecular markers, natural history and evolution. New York: Chapman e Hall. 1993, 511p.

BARBIERI, R.L.; LEITE, D.L.; EVA CHOER, E.; SINIGAGLIA, C. Divergência genética entre populações de cebola com base em marcadores morfológicos. Ciência Rural, v.35, n.2, p.303-308, 2005.

BASSAM, B.J.; CAETANO ANOLLES, G.; GERSSHOFF, P.M. Fast and sensitive silver staining of DNA in polyacrilamide gels. Analyt Biochem. 196: 80-83, 1991. 
FACULDADE DE AGRONOMIA E MEDICINA VETERINÁRIA

Programa de Pós Graduação em Agronomia

BORÉM, A. Melhoramento de Plantas. Viçosa: UFV, 1997. 547 p.

BORÉM, A.; MIRANDA, G.V. Melhoramento de Plantas. Viçosa: UFV, 2013. 523 p.

BOS, I; CALIGARI, P. Selection methods in plant breeding. Chapman and Hall, Londres, 1995.

BRONDANI, R.P.V.; BRONDANI, C.; TARCHINI, R.; GRATTAPAGLIA, D. Development, characterization and mapping of microsatellite markers in Eucalyptus grandis and E.urophylla. Theoretical and Applied Genetics, v.97, p.816-827, 1998.

BRONDANI, C; BRONDANI, R.P.V.; RANGEL, P.H.N.; FERREIRA, M.E. Development and mapping of Oryza glumaepatula - derived microsatellite markers in the interspecific cross Oryza glumaepatula x O.sativa. Hereditas, v. 134, p. 59-71, 2001.

BUSO, G.S.C.; BRONDANI, R.V.; AMARAL, Z.P.S.; REIS, A.M.M.; FERREIRA, M.E. Desenvolvimento de primers SSR para análise genética de pimentas e pimentões (Capsicum spp.) utilizando biblioteca genômica enriquecida. Boletim Técnico da EMBRAPA/EPAGRI, Brasília, n.15, p.01-27, 2000.

BUSO, G.S.C.; AMARAL, Z.P.; BRONDANI, R.V.; MORETZOHN, M.C.; BRONDANI, C.; FERREIRA, M.E. Development and characterization of simple repeat markers for Phaseolus vulgaris. In: 47 CONGRESSO NACIONAL DE GENÉTICA, 2001, Águas de Lindoia. Congresso Nacional de Genética, 47. Águas de Lindoia: Sociedade Brasileira de Genética, 2001a.V.Anais.

BUSO, G.S.C.; CIAMPI, A.Y.; MORETZSOHN, M.C.; AMARAL, Z.P.S.; BRONDANI, R.V. Marcadores Microssatélites em Espécies Vegetais. Desenvolvimento e Caracterização de Marcadores Microssatélites em Espécies Vegetais Tropicais. Biotecnologia, Ciência e Desenvolvimento. Brasília, Ed. 30. P. 46-50. Jan-jun. 2003.

BUSO, G.S.C. Marcadores Moleculares e Análise Filogenética. In: Marcadores moleculares e análise filogenética e Utilização de DNA na análise filogenética. Brasília: Embrapa Recursos Genéticos e Biotecnologia, 2005. p. 7-10.

BUSO, G.S.C.; CIAMPI, A.Y.; AZEVEDO, V.C.R.; AREND, D.; FERREIRA, M.A.; MORETZSOHN, M.C.; AMARAL, Z.P.S.; MAZZUCATO, A. Manual de Utilização de Marcadores Moleculares para Análise de Diversidade Genética. Brasília: Embrapa Recursos Genéticos e Biotecnologia; programa Biodiversidade Brasil-Itália; Universitá degli Studi della Tuscia. 2009,32 p.

CHO, R.J.; MINDRINOS, M.; RICHARDS, D.R.; SAPOLSKY, R.J.; ANDERSON, M.; DRENKARD, E.; DEWNEY, J.; REUBER, T.L.; STAMMERS, M.; FEDERSPIEL, N.; THEOLOGIS, A.; YANG, W.H.; HUBBELL, E.; AU, M.; CHUNG, E.Y.; LASHKARI, D.; LEMIEUX, B.; DEAN, C.; LIPSCHUTZ, R.J.; AUSUBEL, F.M.; DAVIS, R.W.; OEFNER, P.J. Genome-wide mapping whith biallelic markers in Arabidopsis thaliana. Nature Genetics, New York, v.23, p.203-207, 1999. 
CHUNG, S.M.; STAUB, J.E.; CHEN, J.F. Molecular phylogeny of Cucumis species as revealed by consensus chloroplast SSR marker length and sequence variation.Genome, v.49, p. 219-229, 2006.

COGNIAUX, A.; HARMS, H. Cucurbitaceae - Cucurbiteae - Cucumerineae. In: Das Pflanzenreich Regni vegetabilis conspectus (A. Engler ed.). Wilhelm Engelmann, Leipzig (DE), vol. 88 (IV. 275.II). p. 116-157, 1924.

COLLEVATI, R.G.; BRONDANI, R.V.; GRATTAPAGLIA, D. Development and characterization of microsatellite markers for genetic analysis of a Brazilian endangered species Caryocar brasiliense. Heredity, v.83, p. 748-756, 1999.

COMPANHIA DE ENTREPOSTOS E ARMAZÉNS GERAIS DE SÃO PAULO CEAGESP 2010. Disponível em: 〈http://www.ceagesp.gov.br〉. Acesso em: 02 fevereiro 2016.

COSTA, C. P. \& PINTO, C. A. B. P. Melhoramento do melão. In: Melhoramento de Hortaliças. Piracicaba: USP/ESALQ, 1977. 161-165.

COSTA, N.D.; DIAS, R.C.S.; FARIA, C.M.B.; TAVARES, S.C.C.H.; TERAO, D. Cultivo do melão. Petrolina: Embrapa Semi-árido, 2000. 67p.

COSTA, J.C. Utilização de Marcadores ISSR na Caracterização de Cultivares. 2010. 17f. Revisão de literatura (Mestrado em Agronomia: (Melhoramento Genético Vegetal). Universidade Federal Rural de Pernambuco, Recife, 2010.

CRESTE, S.; TULMANN-NETO, A.; FIGUEIRA. Detection of sigle sequence repeat polymorphisms in denaturing polyacrilamide sequencing gels by silver staining. Plant Molecular Biology Reporter, v.19, p.299-306, 2001.

CRISÓSTOMO, J. R. Melhoramento do meloeiro para resistência a doenças e qualidade do fruto. Fortaleza, 2000. 23p. Relatório final de projeto. convênios: Embrapa Agroindústria Tropical / CNPq / ESAM /VALEFRUTAS. 2000.

CRUZ, C.D., REGAZZI, A.J. Modelos biométricos aplicados ao melhoramento genético. 2. ed. Viçosa: UFV, 1997. 390 p.

CUI, Z. et al., Phenotypic diversity of modern Chinese and North American soybean cultivars. Crop Science, Saint Paul, v.41, p.1954-1967, 2001.

DANIN-POLEG, Y.; REIS, N.; TZURI, G.; KATZIR, N. Development and characterization of microsatellite markers in Cucumis. Theoretical and Applied Genetics, v. 102, p. 61-72, 2001.

DE CANDOLE, A. Origen of cultivated plant. New York: Hafner, 1882. p.258-262.

DELEU, W.; ESTERAS, C.; ROIG, C.; GONZÁLEZ-TO, M.; FERNÁNDEZ-SILVA, I.; GONZALEZ-IBEAS, D.; JOSÉ BLANCA, J.; ARANDA, M.A., ARÚS, P.; FERNANDO NUEZ, F.; MONFORTE, J.A.; MARIA BELÉN PICÓ, M.B.; GARCIA-MAS, J. A set of 
FACULDADE DE AGRONOMIA E MEDICINA VETERINÁRIA

Programa de Pós Graduação em Agronomia

EST-SNPs for map saturation and cultivar identification in melon. BMC Plant Biology, v.9, p.1-9, 2009.

DIAS, R. DE C.S., coord. A Cadeia Produtiva do Melão na Região Nordeste. EMBRAPA SEMI-ÁRIDO, 1997, 73p.

ESTERAS, C.; FORMISANOS, G.; ROIG, C.; DÍAS, A.; BLANCA, J.; GARCIA-MAS, J.; GÓMEZ-GUILLAMÓN, M.L.; LÓPEZ-SESÉ, A.I.; LÁZARO, A.; MONFORTE, A.J.; PICÓ, B. SNP genotyping in melons: genetic variation, population structure, and linkage disequilibrium. Theoretical Applied Genetics, v.126, p.1285-1303, 2013.

ESCRIBANO, S.; LÁZARO, A. Agro-morphological diversity of Spanish tradicional melons (Cucumis melo L.) of the Madrid provenance. Genetic Resource Crop Evolution, v.56, p.481-497, 2009.

FALEIRO, F.G.; PIRES, J.L.; LOPES, U.V. Uso de marcadores moleculares RAPD e microssatélites visando a confirmação da fecundação cruzada entre Theobroma cacao e Theobroma grandiflorum. Agrotrópica, Itabuna, v.15, p.41-46, 2003.

FALEIRO, F.G. Marcadores Genético-moleculares - Aplicados a programas de conservação e uso de recursos genéticos. Planaltina - DF: Embrapa Cerrados, 2007. 99 p.

FAO (Food and Agriculture Organization). Base de Dados Agrícolas de FAOSTAT, 2009 Disponível em: 〈http://faostat.fao.org/DesktopDefault.aspx?PageID=339\&lang=es > Acesso em: 22 dezembro 2014.

FAO (Food and Agriculture Organization). Base de Dados Agrícolas de FAOSTAT, 2012 Disponível em: 〈http://faostat.fao.org/DesktopDefault.aspx?PageID=339\&lang=es > Acesso em: 22 dezembro 2014.

FEHR, W.R. Principles of Cultivar Development - Theory and Technique. New York: Macmillan Publishing Co. 1987. v.1. 536 p.

FERREIRA, M.E.; GRATTAPAGLIA, D. Introdução ao uso de marcadores moleculares em análise genética. Brasília: EMPRAPA-CENARGEN, 3ed. 1998. 220 p.

FERREIRA, P.V. Melhoramento de plantas, Princípios e perspectivas. In: FERREIRA, P.V. (Ed.). Sistemas Reprodutivos nas espécies cultivadas. Maceió: UFAL, 2006. p. 86-92.

FILGUEIRA, F. A. R. Novo manual de olericultura: agrotecnologia moderna na produção e comercialização de hortaliças. Viçosa: Editora UFV, 3 ed. 421p. 2008.

FILGUEIRA, F.A.R. Manual de Olericultura: cultura e comercialização de hortaliças.8 ed. São Paulo: Agronômica Ceres, 1972. 451p.

FILOV, A.I. The problem of melon systematics. Vestnik sel'skochozjajstvennoj nauki, v.1, p.126-132, 1960 
FORSBERG, R.A; SMITH, R.R. Sources, maintenance, and utilization of parental material. In: FEHR, W.R.; Hadley, H.H. Hybridization of Crop Plants. American Society of Agronomy: Crop Science Society of America, p.65-81, 1980.

FUKINO, N. et al., Identification of QTLs for resistence to powdery mildew ans SSR markers diagnostic for powdery mildew resistence genes in melon (Cucumis melo L.). Theoretical and Applied Genetics.v. 118, p. 165-175, 2008.

GALLEGO, J.F.; PÉREZ, A.M.; NUÑEZ, Y.; HIDALGO, P. Comparison of RAPDs, AFLPs and SSR markers for the genetic analysis of yeast strains of Saccharomyces cerevisiae. Food Microbiology, v.22, p. 561-568, 2005.

GARCIA, E.; JAMILENA, M.; ALVAREZ, J. I.; ARNEDO, T.; OLIVER, J. L.; LOZANO, R. Genetic relationships among melon breeding lines revealed by RAPD markers and agronomic traits. Theoretical and Applied Genetics, v. 96, p. 878-885, 1998.

GARCIA-MAS, J.; OLIVER, M.; GÓMEZ-PANIAGUA, M.C.V. Comparing AFLP, RAPD and RFLP markers for measuring genetic diversity in melon. Theoretical and Apllied Genetics, v.101, p. 860-864, 2000.

GARCIA-MAS, J., MONFORTE A.J.; ARÚS, P. Phylogenetic relationships among Cucumis species based on the ribosomal internal transcribed spacer sequence and microsatellite markers. Plant Systematic Evolution, v.248, p.191-203, 2004.

GARCIA-MAS, J.; BENJAK, A.; SANSEVERINO, W.; BOURGEOIS, M.; MIR, G.; GONZÁLEZ, V.M.; HÉNAFF, E.; CÂMARA, F.; COZZUTO, L.; LOWY, E.; ALIOTO, T.; CAPELLA-GUTIÉRREZ, S.; BLANCA, J.; CAÑIZARES, J.; ZIARSOLO, P.; GONZALEZIBEAS, D.; RODRÍGUEZ-MORENO, L.; DROEGE, M.; DU, L.; ALVAREZ-TEJADO, M.; LORENTE-GALDOS, B.; MELÉC, M.; YANG, L.; WENG, Y.; NAVARRO, A.; MARQUES-BONET, T.; ARANDA, M.A.; NUEZ, F.; PICÓ, B.; GALBADÓN, T.; ROMA, G.; GUIGÓ,R.; CASACUBERTA, J.M.;ARÚS, P.; PUIGDOMÉNECH, P. The genome of melon (Cucumis melo L.). Proceedings of the National Academy of Sciences of the United States of America, Washington, DC.v.109, n.29.Julho, 2012.

GOLDMAN, L; AUSIELlO, D. et al., Tratado de Medicina Interna. In: HALL, J. (Ed.). Distúrbio Homogênicos e Cromossômicos. [tradução de Ana Kepler et al.,] Rio de Janeiro: Elsevier, 2005. p. 230.

GÓMEZ-GUILlamón, M.L.; CUARTERO, J.; CORTÉS, C.; ABADIA, J.; COSTA, J.; NUEZ, F. Descripción de cultivares de melón: caracteres cuantitativos. Actas I del Congreso Nacional de la Sociedad Española de Ciencias Hortícolas. Valencia, 28 Noviembre1 Diciembre 1983, p. 453-460, 1983.

GÓMEZ-GUILlamóN, M.L.; ABADIA, J.; CUARTERO, J.; CORTÉS, C.; NUEZ, F. Characterization of melon cultivars. Cucurbit Genetics Cooperative Report, v.8, p. 39-40, 1985. 
GONTIJO, S.L.; AMORIM, J.C.; AMARAL, Z. P. S.; BUSO, J.A.; PAIVA, W. O.; OLIVEIRA, V. R.; BUSO, G.S.C. Estudo da variabilidade genética entre 162 linhagens de melão utilizando marcadores moleculares RAPD. In: CONGRESSO BRASILEIRO DE OLERICULTURA, 46. Goiânia. Resumos... Goiânia: Horticultura Brasileira, v.24, n.1, julho 2006 (suplemento). p.132-133.

GORGATTI NETO A; GAYET JP; BLEINROTH EW; MATALLO M; GARCIA EEC; GARCIA AE; ARDITO EFG; BORDIN MR. 1994. Melão para exportação: procedimentos de colheita e de pós colheita. Brasília: EMBRAPA - SPI/FRUPEX, 37p. (EMBRAPA- SPI. Publicações Técnicas, 6).

HAWKES, J.G.; Germplasm Collection, preservation, and use. In: FREY, K.J. Plant Breeding II. Ludhiana: Kalyani Publishers: New Delhi. 1982. p. 57-83.

HOFFMANN, L.V.; BARROSO, P.A.V. Marcadores Moleculares como Ferramentas para Estudos de Genética de Plantas. Campina Grande: Embrapa Algodão, 2006. 36p.

IBGE - Instituto Brasileiro de Geografia e Estatística. Produção Agrícola Municipal, Culturas temporárias e permanentes, 2010. 89 p. Disponível em: <http://www.ibge.gov.br/home/estatistica/economia/pam/2010/PAM2010_Publicacao_compl eta.pdf> Acesso em: 22 dezembro 2014.

IBGE - Instituto Brasileiro de Geografia e Estatística. Banco de Dados Agregados, 2014. Disponível http://www.sidra.ibge.gov.br/bda/agric/default.asp?t=1\&z=t\&o=11\&u1=1\&u2=1\&u3=1\&u4= 1\&u5=1\&u6=1> Acesso em: 22 dezembro 2014.

JOSÉ, M.A.; IBAN, E.; SILVIA, A.; PERE, A. Inheritance mode of fruit traits in melon: heterosis for fruit shape and its correlation with genetic distance. Euphytica, v.144, p.31-38, 2005 .

KALIA, R.K.; RAI, M.K.; KALIA, S.; SINGH, R.; DHAWAN, A.K. Microsatellite markers: an overview of the recent progress in plants. Euphytica 177, 309-334, 2011.

KARCHI, Z. Development of melon culture and breeding in Israel. Proceedings of $7^{\text {th }}$ EUCARPIA Meeting of Cucurbit Genetics and Breeding. Acta Horticulture, v.510, p. 13-17, 2000 .

KATZIR, N.; DANIN-POLEG, Y.; TZURI, G.; KARCHI, Z.; LAVI, U.; CREGAN, P.B. Length polymorphism and homologies of microsatellites in several Cucurbitaceae species. Theoretical and Applied Genetics, v. 93, p.1282-1290, 1996.

KIMCHI-SARFATY, C.; OH, J.M.; KIM, IN-WHA.; SAUNA, Z.E.; CALCAGNO, A.M.; AMBUDKAR, S.V.; GOTTESMAN, M.M. A "Silent" Polymorphism in the MDR1 Gene Changes Substrate Specificity. Science, v.26, p.525-528, 2007. 
FACULDADE DE AGRONOMIA E MEDICINA VETERINÁRIA

Programa de Pós Graduação em Agronomia

KIRKBRIDE, J.H.Jr. 1993. Biosystematics Monograph of the genus Cucumis (Cucurbitaceae): botanical identification of cucumbers and melons. North Carolina: Parkway Publishers. $159 \mathrm{p}$.

LABORDA, P.R.; OLIVEIRA, K.M.; GARCIA, A.A.F.; PATERNIANI, M.E.A.G.Z.; SOUZA, A.P. Tropical maize germplasm: what can we say abouts its genetic diversity in the light of molecular markers? Theoretical and Applied Genetics, v.111, p.1288-1299, 2005.

LESTER GE; EISCHEN F. Beta-carotene content of postharvest orange-fleshed muskmelon fruit. Plant Foods and Human Nutrition, v.49, p.191-197, 1996.

LEWIS, P.O.; ZAYKIN, D. (2001).GDA - pc Genetic Data Analysis, Version 1.1.

LIMA, J.A.A \& VIEIRA, A.C.Distribuição do vírus do mosaico da abóbora em municípios cearenses e gama de hospedeiras e um isolado. Fitopatologia brasileira, n.17p.112-114, 1992.

LOCK, K.; POMERLEAU, J.; CAUSER, L.; ALTMANN, D.R.; MCKEE,M. The global burden of desease attributable to low consumption of fruits and vegetables: implication for the global strategy on diet. Bulletin of the World Health Organ, v.83, n.2, p.100-108, 2005.

LOPES, J.F.; CARVALHO, S.I.C.; PESSOA, H.B.S.V. Recursos Genéticos de Melão e Pepino na Embrapa Hortaliças. Recursos Genéticos e Melhoramento de Plantas para o Nordeste Brasileiro, Petrolina, 8p., novembro, 1999.

LOPES, R.; LOPES, M.T.G.; FIGUEIRA, A.V.O.; CAMARGO, L.E.A.; FUNGARO, M.H.P.; CARNEIRO, M.S.; VIEIRA, M.L.C. Marcadores Moleculares Dominantes (RAPD e AFLP): Aspectos técnicos e interpretação genética. Biotecnologia, Ciência e Desenvolvimento, n.29, p. 56-60, 2002.

MAIA, A.K.S.; ALBUQUERQUE, L.B.; ANTONIO, R.P.; SILVEIRA, L.M.; NUNES, G.H.S.; SILVA, A.E.A.; DANTAS, A.C.A. Tranferibilidade de Marcadores Microssatélites de Melão para Melancia. In: CONGRESSO INTERNACIONAL DE CIÊNCIAS BIOLÓGICAS, 1. CONGRESSO NACIONAL DE CIÊNCIAS BIOLÓGICAS, 2. SIMPÓSIO DE CIÊNCIAS BIOLÓGICAS, 4, 2013, Pernambuco. Resumos do... Pernambuco: SIMCBIO, 2013. p.8.

MALLICK M.F.R.; MASSUI, M. Origin, distribution and taxonomy of melos. Scientia Horticulturae, Amsterdam, v.28, p.251-261, 1986.

MATHEW, S.M.; GOPALARKRISHNAN, P.K.; PETER, K.V. Compatibility among Cucumis melo varieties inodorus, conomon, flexuosus, momordica and utilissimus. Cucurbit Genetics Cooperative Report, v.9, p. 78-80, 1986.

McCREIGHT, J.D.; NERSON, H.; GRUMET, R. Melon, Cucumis melo L. In: KALLOS, G.; BERGH, B.O. Genetic improvement of vegetable crops. Pergamon Press, New York, 1993. 
FACULDADE DE AGRONOMIA E MEDICINA VETERINÁRIA

Programa de Pós Graduação em Agronomia

MELLOTO, M.; KELLY, J.D. Fine mapping of the Co-4 locus of common bean reveals a resistance gene candidate, $\mathrm{COK}-4$, that encodes for a protein kinase. Theoretical and Applied Genetics, New York, v.103, p.508-517, 2001.

MENEZES, J. B.; FILGUEIRAS, H.A.C.; ALVES, R.E.; MAIA, C.E.; ANDRADE, G.G.; ALMEIDA, J.H.S.; VIANA, F.M.P. Características do melão para exportação. Melão póscolheita, Série Frutas do Brasil, 10. Brasília, n.1, p.13-16, 2000.

MENEZES, J.B.; GOMES JÚNIOR, J.; ARAÚJO NETO, S.E.; SIMÕES, A.N. Armazenamento de dois genótipos de melão amarelo sob condições ambiente. Horticultura Brasileira, v.19, n.1, p. 42-49, 2001.

MILLACH, S.C.K. Marcadores moleculares nos recursos genéticos e no melhoramento de plantas. Recursos Genéticos e Melhoramento de Plantas para o Nordeste Brasileiro, Petrolina, 8p., novembro, 1999.

MLIKI, A.; STAUB, J.E.; SUN, Z.Y.; GHORBEL, A. Genetic diversity in melon (Cucumis melo L.): an evaluation of African germplasm. Genetic Resources and Crop Evolution, v.48, p. 587-597, 2001.

MUNGER, H.N.; ROBINSON, R.W. Nomeclature of Cucumis melo L. Curcubits Genetic Cooperative, Madison, v.14, p. 43-44, 1991.

NAUDIN, C.V. Essais d'une monographie des espèces at des variétés du genre Cucumis. Annuales des Sciences Naturelles: Botanique. Série 4, v.11, p.5-87, 1859.

NEALE, D.B.; WILLIAMS, C.G.; Restriction Fragment polymorphism mapping in conifers and applications to forest genetics and tree improvement Canadian Journal of Forest Research. Otawa, v.21, p. 545-554, 1991.

NUNES, G.H. de S.; SANTOS JÚNIOR, J.J.S.; VALE, F.A.; BEZERRA NETO, F.; ALMEITA, A.H.B.; MEDEIROS, D.C. Aspectos produtivos e de qualidade de híbridos de melão cultivados no Agropólo Mossoró-Assú. Horticultura Brasileira, v.22, n.4, p. 744-747, 2004.

NUNES, E.W.L.P. Caracterização de germoplasma, herança e identificação de marcadores SNP associados à resistência a Podosphaera xanthii em meloeiro. 2014. 124 f. Tese (Doutorado em Agronomia: Fitotecnia). Universidade Federal Rural do Semi-árido, Mossoró, 2014.

NUÑEZ-PALENIUS H.G. et al. Transformation of a muskmelon 'Galia' hybrid parental line (Cucumis melo L. var. reticulatus Ser.) with an antisense ACC oxidase gene. Plant Cell Reporter, v.25, p.198-205. 2006. 
FACULDADE DE AGRONOMIA E MEDICINA VETERINÁRIA

Programa de Pós Graduação em Agronomia

OFFEI, S.K.; ASANTE, I.K.; DANQUAH, E.Y. Genetic structure of seventy cocoyam (Xanthosoma sagitifolium, Linn, Schott) accessions in Ghana based on RAPD. Hereditas, 140: p.123-128, 2004.

OHSE, B.J.G. Desenvolvimento de marcadores microssatélites (SSRs) para análise genética de melão (Cucumis melo L;). 2005. 33 F. Trabalho de Conclusão de Curso (Graduação em Biologia). Centro Universitário de Brasília, Brasília, 2005.

OLIVEIRA, L.B.; RAMALHO, M.A.P.; ABREU, A.F. Alternative procedures for parente choice in a breeding program for common bean (Phaseolus vulgaris L.). Brasilian Journal of Genetics, Ribeirão Preto, v.19, n.4, p. 611-615, 1996.

PAIVA de, W.O. Recursos genéticos e melhoramento de plantas para o Nordeste brasileiro - Melhoramento genético do melão. Petrolina: EMBRAPA Semi-Árido, 1999. 12 p.

PAIVA, W.O.; FILGUEIRAS, H.A.C.; LIMA, J.A.A.; BUSO, G.S.C.; BUSO, J.A. Melão Tupã: Origem e Melhoramento Genético. Fortaleza: Embrapa Agroindústria Tropical, 2002. 37 p.

PANGALO, K.I. Watermelon of northern hemisphere. Bull. Appl. Bot. Genet. Plant Breed., v.23, p.41-84, 1930.

PANGALO, K I. Cucurbitacées. In La Turquie Agricole (P. Zhukovsky ed.). Les éditions de I'Etat section agricole "Selkhozghiz", p. 518-559, 873-882. 1933.

PESSOA, H.B.S.V.; AVILA, A.C.; DELLA VECCHIA, P.T.; ARAUJO, J.P.; OLIVIEIRA, L.O.B. Eldorado 300: melão resistente ao vírus do mosaico da melancia WMV-1. Horticultura brasileira, Brasília-DF, v.6,n.1, p.40-41, 1988.

PUIGDOMÈNECH P. et al. The Spanish melon genomics initiative. Acta Horticulturae, v.731, p.47-54. 2007.

PITRAT, M.; HANELT, P.; HAMER, K. Some comments on intraspecific classification of cultivars of melons. Procedings of $7^{\text {th }}$ EUCARPIA meeting on Curcubit Genetics and Breeding. Acta Horticulture.V.510, p.29-36, 2000.

QUEIROZ, M.A. Germplasm of curcubitaceae in Brazil. Crop Breeding and Applied Biotechnology, v.4, p 377-383, 2004.

QUEIROZ, M.A.; LOPES, M.A. Importância dos recursos genéticos vegetais para o agronegócio, In: NASS, L.L. Recursos Genéticos Vegetais. Brasília, DF. Embrapa Recursos Genéticos e Biotecnologia, p. 61-120, 2007.

QUIRINO, M.S. Polimorfismos de sequência nucleotídica em fragmentos genômicos de cana-de-açúcar homólogos a genes de resistência. 2003. 52 f. Dissertação (Mestrado em Agronomia) - Escola Superior de Agricultura Luiz de Queiroz, Universidade de São Paulo, Piracicaba, 2003. 
FACULDADE DE AGRONOMIA E MEDICINA VETERINÁRIA

Programa de Pós Graduação em Agronomia

RAMOS, S.R.R.; QUEIROZ, M.A.de; PEREIRA, T.N.S. Recursos genéticos vegetais: Manejo e uso. Magistra, v.19, p. 265-273, 2007.

REZENDE, R.K.S.; PAIVA, L.V.; PAIVA, R.; CHALFUN JUNIOR, A.; TORGA, P.P.; MASETTO, T.E. Divergência genética entre cultivares de gérbera utilizando marcadores RAPD. Ciência Rural, v.39, p. 2435-2440, 2009.

RITSCHEL, P.S.; LINS, T.D.de L.; TRISTAN, R.L; BUSO, G.S.C.; BUSO, J.A.; FERREIRA, M.E. Development of microsatellite markers from an enriched genomic library for genetic analysis of melon (Cucumis melo L.). BMC Plant Biology, v.4, n.1, p.9-24, 2004.

ROBINSON, R.W.; DECKER-WALTERS, D.S. Curcubits. New York: CAB International, 1997. 226p.

SAIKI, R.K.; BUGUWAN, G.T.; HORN, G.T.; MULLIS, K.B.; ERLICH, H.A. Primerdirected enzymatic amplification of DNA with a semi-stable DNA polymerase, Science, v.239, p. 487-494, 1988.

SESTILI, S.; DANIELE, A.; ROSA, A.; FERRARI, V.; BELISARIO, A.; FICCADENTI, N. 2008. Molecular characterization of different Italian inodorus melon populations based on ISSR molecular markers and preliminary SSR analysis. Pitrat M. (ed): Cucurbitaceae 2008, IX EUCARPIA genetics and breeding of Cucurbitaceae, Avignon (France), Maio 2008, p. 307-311.

SILVA, D.J.H.; MOURA, M.C.C.L.; CASALI, V.W.D.; Recursos Genéticos do Banco de Germoplasma de Hortaliças da UFV: histórico e expedições de coleta. Horticultura Brasileira, v.19, p. 108-114, 2001.

SILVA, H.R.; COSTA, N.D. Melão, Produção Aspectos técnicos, Série Frutas do Brasil. Brasília-DF: Embrapa Semi-Árido, 2003. 144p.

SILVA, M.L.; QUEIROZ, M.A.; FERRERIA, M.A.J.F.; BENKO-ISEPPOM, A.M. 2012. Caracterização molecular por ISSR de acessos de melancia do Banco Ativo de Germoplasma de Cucurbitáceas. Horticultura Brasileira v.30, n.2, p.4445-4451, 2012.

SOUSA, R.M.; AGUIAR, O.S.; FREITAS, B.M.; SILVEIRA NETO, A.A.; PEREIRA, T.F.C. Requerimentos de Polinização do meloeiro (Cucumis melo L.) no município de Acaraú - CE - Brasil. Caatinga, v.22, n.1, p. 238-242, 2009.

STAUB, J.E.; LÓPEZ-SESÉ, A.I.; FANOURAKIS, N. Diversity among melon landraces (Cucumis melo L.) from Greece and their genetic relationships with other melon germplasm of diverse origins. Euphytica, v.136, p.151-166, 2004.

SZABÓ, Z.; GYULAI, G.; HUMPHREYS, M.; HORVÁTH, L.;BITTSÁNSZKY, A.; LÁGLER, R.; HESZKY. L. Genetic variation of melon (C. melo) compared to an extinct landrace from the Middle Ages (Hungary) I. rDNA, SSR and SNP analysis of 47 cultivars. Euphytica, v.146, p.87-94, 2005. 
FACULDADE DE AGRONOMIA E MEIDICINA VETERINÁRIA

Programa de Pós Graduação em Agronomia

TEIXEIRA, A.P.M. Identificação de marcadores moleculares ligados a gene de resistência ao vírus do mosaico PRSVw em melão (Cucucmis melo L.). 2004. Tese (Mestrado em Fitopatologia: Melhoramento Genético Vegetal). Escola Superior de Agricultura Luiz de Queiroz, ESALQ, Piracicaba, 2004.

TORRES FILHO, J. Caracterização morfo-agronômica, seleção de descritores e associação entre a divergência genética e a heterose em meloeiro. 2008. 150 p. Tese (doutorado em fitotecnia) - Universidade Federal Rural do Semi-Árido, Mossoró, 2008.

VALLS, J.F.M. Caracterização morfológica, reprodutiva e bioquímica de germoplasma vegetal. In: ENCONTRO SOBRE RECURSOS GENÉTICOS, 1., Jaboticabal, 1988. Anais...Jaboticabal, FCAV/UNESP, p.106-128, 1988.

WANG, Y.H.; THOMAS, C.E.; DEAN, R.A. A genetic map of melon (Cucumic melo L.) based on amplified fragmente length polymorphism (AFLP) markers. Theoretical and Applied Genetics, v.95, p. 791-797, 1997.

WELSH, J.; McCLELLAND, M. Fingerprinting genomes using PCR with arbitrary primers. Nucleic Acids Res., v.18, p. 7213-7218, 1990.

WILLIAMS, J.G.; KUBELIK, A.R.; LIVAK, K.J.; RAFALSKI, J.A.; TINGEY, F.G. DNA Polymorphism amplified by arbitrary primers are useful as genetic markers. Nucleic Acids Research, v.18, p.6531-6535, 1990.

WHITAKER, T.W.; DAVIS, G.N Curcubits: botany, cultivation, and utilization. London: [s.n.], 1962. 249p.

WOLTERS, P.; POWELL, W.; LABUDAH, E.; SNAPE, J.; HENDERSON, K. Nucleotide diversity at homeologus loci in wheat. In: PLANT AND ANIMAL GENOME CONFERENCE, 8.,2000, San Diego Abstracts...San Diego: [s.n.], 2000. p.103.

YARIV Y. et al. The isolation and characterization of fruit ripening-related genes in melon (Cucumis melo) - a genomic approach. In: Cucurbitaceae 2002 (D.N. MAYNARD, ed.), p.421-426. Alexandria, VA. 2002.

ZANE, L.; BARGELLONI, L.; PATARNELLO, T. 2002. Strategies for microssatelite isolation: a revew. Mol.Ecol. 11: 1-16.

ZUCCHI, M.I.; CAVALLARI, M.M.; SIQUEIRA, M.V.B.M.; A Importância do Conhecimento sobre Diversidade e Estrutura Genética de Populações e sua Utilidade para Conservação e Manejo de Espécies Vegetais. Pesquisa e Tecnologia, Guanabara (SP), v. 8, n. 2, 6p. , Jul-Dez, 2011. 
FACULDADE DE AGRONOMIA E MEDICINA VETERINÁRIA

Programa de Pós Graduação em Agronomia

\section{CAPÍTULO 1}

\section{Análise da variabilidade genética de linhagens de melão utilizando marcadores moleculares SSR e ISSR.}

\section{RESUMO}

Este estudo avaliou a variabilidade genética de linhagens de três tipos de melão, Pele de Sapo, Amarelo e Cantaloupe, provenientes do Programa de melhoramento de melão da Embrapa Hortaliças. Foram coletadas folhas de plântulas de 255 linhagens parcilamente endogâmicas, sendo 58 do tipo Pele de Sapo, 141 do tipo Amarelo e 56 do tipo Cantaloupe. Foi realizada extração do DNA genômico e posteriormente, quantificação do mesmo. Foram utilizados marcadores SSR para avaliação de todas as linhagens e adicionalmente, marcadores ISSR apenas para os genótipos tipo Pele de Sapo, sendo ambos amplificados por meio de reações de PCR. Os marcadores SSR amplificaram um total de 45 alelos para os genótipos Pele de Sapo, enquanto que os marcadores ISSR amplificaram 74 bandas polimórficas. Os dendrogramas gerados por ambos marcadores (SSR e ISSR) apresentaram resultados satisfatórios permitindo-se sugerir maior heterose pelo cruzamento entre linhagens dos dois principais grupos divergentes, e a utilização das linhagens 43 e 25, provavelmente, aumentará a variabilidade alélica no programa de melhoramento. Os marcadores SSR amplificaram um total de 78 alelos para os genótipos Amarelo e o dendrograma gerado pela análise apresentou os 141 genótipos com similaridade genética variando de 0,52 a 1. Maior heterose pode ser obtida pelo cruzamento entre os genótipos dos dois principais grupos divergentes, e a utilização dos genótipos 5 e 124, provavelmente aumentará a variabilidade alélica no programa de melhoramento. Para os genótipos Cantaloupe, os marcadores SSR amplificaram um total de 103 alelos. O dendrograma resultante agrupou os 56 genótipos com similaridade genética variando de 0,49 a 1, prevendo-se maior heterose pelo cruzamento entre linhagens dos dois principais grupos divergentes, e a utilização do genótipo 18, provavelmente aumentará a variabilidade alélica no programa de melhoramento. Por fim, foi encontrada, em todas as linhagens, a maioria dos locos em homozigose e ambos marcadores foram eficientes na análise apresentando ampla variabilidade genética e possibilitando sugestões dos melhores cruzamentos para obtenção de híbridos superiores e maior heterose. 
UNIVERSIDADE DE BRASÍLIA

FACULDADE DE AGRONOMIA E MEDICINA VETERINÁRIA

Programa de Pós Graduação em Agronomia

Palavras-Chave: Cucumis melo L. , Variabilidade genética, Linhagens, SSR, ISSR. 
FACULDADE DE AGRONOMIA E MEDICINA VETERINÁRIA

Programa de Pós Graduação em Agronomia

\begin{abstract}
This study evaluated the genetic variability of lines of three kinds of melon, Pele de Sapo, Yellow and Cantaloupe, melon from the breeding program of Embrapa Hortaliças. Leaves of seedlings of 255 inbred lines were collected, 58 of Pele de Sapo, 141 of Yellow and 56 of the type Cantaloupe. It was performed genomic DNA extraction and subsequently quantification. SSR markers were used for the evaluation of all lines and, additionally, ISSR markers only for the 58 Pele de Sapo genotypes. Both markers were amplified by PCR reactions. The SSR markers amplified a total of 45 alleles for the Pele de Sapo genotypes, while the ISSR markers amplified 74 polymorphic bands. The dendrograms generated by both markers (SSR and ISSR) showed satisfactory results allowing to suggest a greater heterosis by crossing lines of the two main contrasting groups in both dendrograms, and the use of lines 43 and 25 is likely to increase the allelic variability in the breeding program. The SSR amplified a total of 78 alleles for the Yellow genotypes and the dendrogram analysis showed the 141 genotypes divided into two main groups, with a genetic similarity range of 0.52 to 1 . A greater heterosis is obtained by crossing the genotypes of the two divergent main groups and the use of genotypes 5 and 124, will likely increase the allelic variability in the breeding program. For the Cantaloupe genotypes, the SSR markers amplified a total of 103 alleles. The resulting dendrogram grouped the 56 genotypes with a genetic similarity ranging from 0.49 to 1 , providing a greater heterosis by crossing lines of the two main contrasting groups, and the use of genotype 18, will likely increase the allelic variability in the breeding program. Finally, it was found in all inbred lines, most loci homozygous and both markers were efficient in the analysis showing wide genetic variability and providing suggestions of the best crosses to obtain superior hybrids and more heterosis.
\end{abstract}

Keywords: Cucumis melo L., Genetic variability, Lines, SSR, ISSR. 
FACULDADE DE AGRONOMIA E MEDICINA VETERINÁRIA

Programa de Pós Graduação em Agronomia

\section{INTRODUÇÃO}

O desenvolvimento de cultivares de melão mais adaptadas às regiões do semiárido, que apresentem resistência ou tolerância às principais pragas e doenças, e produzam frutos de qualidade superior, com alto teor de sólidos solúveis, polpa firme e espessa e maior conservação pós-colheita, aumenta a competitividade do fruto brasileiro no mercado internacional e tem representado uma demanda cada vez maior no agronegócio nacional. Programas de melhoramento genético que utilizam técnicas da biologia molecular como ferramentas auxiliares, podem ter maior eficiência e acurácia na seleção de cultivares mais produtivas, uniformes e de alta qualidade.

A seleção de indivíduos superiores, em programas de melhoramento pode se feita de forma indireta por meio do uso de marcadores moleculares. Além dessa aplicação, marcadores moleculares podem ser úteis em análises de variabilidade genética que auxiliam na identificação de parentais divergentes, orientando os melhores cruzamentos, para a obtenção de descendentes com alta variabilidade genética e efeitos heteróticos significativos, além de híbridos superiores, haja vista a correlação entre divergência genética e heterose em alguns casos.

$\mathrm{Na}$ área do melhoramento genético de plantas cultivadas, a quantificação da divergência genética pode auxiliar o melhorista na escolha das linhagens a serem utilizadas em cruzamentos de um programa de melhoramento, de forma a maximizar as diferenças genéticas e a combinação de genes de interesse. Nesta seleção procura-se, normalmente, genitores com grande distância genética com a finalidade de recombinar genes ou complexos gênicos em novas combinações favoráveis (FREITAS \& BERED, 2003).

Diante do exposto, este trabalho teve como objetivo avaliar a variabilidade genética de 255 linhagens endogâmicas de melão oriundas da Embrapa Hortaliças, sendo 58 do tipo Pele de Sapo, 141 do tipo Amarelo e 56 do tipo Cantaloupe, utilizando marcadores moleculares SSR e ISSR, afim de auxiliar na definição de cruzamentos para obtenção dos melhores híbridos com maior heterose. 
FACULDADE DE AGRONOMIA E MEDICINA VETERINÁRIA

Programa de Pós Graduação em Agronomia

\section{MATERIAL E MÉTODOS}

2.1 Material vegetal

O material obtido para o estudo foi proveniente do programa de melhoramento de melão da Embrapa Hortaliças (Centro Nacional de Pesquisa de Hortaliças - CNPH), e consistiu de 255 linhagens parcialmente endogâmicas, em $\mathrm{S}_{4}$, obtidas pelo método de seleção SSD (Single Seed Descent - Descendência de uma única semente), a partir de população $F_{2}$. A seleção partiu de um grupo de linhagens e foram avaliados caracteres de vigor, resistência à pragas e doenças, e qualidade de fruto na região Nordeste.

Foram avaliadas um total de 255 linhagens, sendo 58 do tipo Pele de Sapo, 141 do tipo Amarelo e 56 do tipo Cantaloupe, coletados em casa de vegetação, na fase de plântula. O estudo foi desenvolvido nas dependências do Laboratório de Genética vegetal - LGV, da Embrapa Recursos Genéticos e Biotecnologia.

Foram utilizados marcadores SSR para avaliação de todas as linhagens, e marcadores ISSR apenas para os 58 genótipos tipo Pele de Sapo devido à dificuldade de ocorrência de polimorfismos nestes genótipos.

\subsection{Extração do DNA genômico}

O DNA genômico foi extraído utilizando-se o protocolo de extração CTAB $2 \%$ (FERREIRA \& GRATTAPAGLIA, 1998; BUSO, 2005 - com modificações). Foram utilizadas folhas das plântulas e essa fase envolveu seis etapas: (1): Foram utilizados aproximadamente $200 \mathrm{mg}$ de tecido foliar pesados em balança de precisão, identificadas e individualizadas em tubos tipo eppendorf com "beads" de cerâmica. Foi adicionado $700 \mu \mathrm{L}$ de detergente catiônico CTAB 2\% - Cationic hexadecyl trimethyl ammonium bromide Cetiltrimetilamônio brometo - (1,4 NaCl, 20 mM; EDTA 100 mM; Tris-HCl pH 8,0; PVP $1 \%$ ), responsável pela lise das membranas celulares e $2 \mu \mathrm{L}$ de $\beta$ - mercaptoetanol $0,2 \%$, responsável pela inibição da oxidação do material vegetal. A maceração mecânica para a lise das paredes e membranas celulares foi realizada em máquina "fast-prep". (2): A suspensão obtida foi submetida à temperatura de $65^{\circ} \mathrm{C}$ em banho maria por aproximadamente 1 hora, 
FACULDADE DE AGRONOMIA E MEDICINA VETERINÁRIA

Programa de Pós Graduação em Agronomia

agitando suavemente os eppendorfs, de 10 em 10 minutos, para solubilização e homogeneização. (3): Após banho maria, foram adicionados $600 \mu \mathrm{L}$ de CIA - Solvente orgânico (solução de clorofórmio e álcool isoamílico 24:1). Os tubos foram agitados por inversão durante 5 minutos e submetidos à centrifugação a $12.000 \mathrm{rpm}$ por 10 minutos. Nessa etapa, a fase orgânica (inferior) contendo parede celular, celulose, lipídeos, proteínas e polissacarídeos foi separada da fase aquosa (superior) contendo DNA e RNA. (4): A fase superior foi retirada com auxílio de pipeta de $200 \mu \mathrm{L}$ e transferida para outro eppendorf devidamente identificado. Foi adicionado $400 \mu \mathrm{L}$ de isopropanol gelado $\left(-20^{\circ} \mathrm{C}\right)$, responsável pela precipitação dos ácidos nucléicos totais, e os tubos ficaram armazenados em freezer $20^{\circ} \mathrm{C}$ por uma hora. Após esse período, foi realizada centrifugação a $12.000 \mathrm{rpm}$ por 15 minutos, havendo formação do pellet. (5): O sobrenadante foi descartado cuidadosamente para não se perder o pellet. O pellet foi lavado com $500 \mu \mathrm{L}$ de etanol $70 \%$ duas vezes e posteriormente com $500 \mu \mathrm{L}$ etanol $100 \%$ uma vez, e seco em centrífuga a vácuo por 15 minutos. (6): Adicionou-se $50 \mu \mathrm{L}$ de tampão TE (Tris-EDTA) para ressuspender o pellet e $2 \mu \mathrm{L}$ de RNase $(10 \mathrm{mg} / \mathrm{mL})$, incubando as amostras em estufa a $37^{\circ} \mathrm{C}$ por 30 minutos para digestão do RNA restando apenas o DNA genômico desejado.

\subsection{Quantificação e diluição do DNA obtido}

Para verificar a quantidade e qualidade do DNA extraído, o mesmo foi quantificado por meio de eletroforese horizontal em gel de agarose $1 \%$ contendo brometo de etídeo. Foi utilizado DNA $\lambda$ com concentração de 200 e 400 ng (total) como comparativo para o DNA concentrado. A diluição do DNA foi feita com água, utilizando-se o cálculo a seguir:

$\mathrm{C}_{1} \times \mathrm{V}_{1}=\mathrm{C}_{2} \times \mathrm{V}_{2}$

Onde:

$\mathrm{C}_{1}=$ Concentração do DNA estimada no gel.

V1= Volume de água a ser adicionado para concentração de trabalho $(3 \mathrm{ng} / \mu \mathrm{L})$.

$\mathrm{C}_{2}=$ Concentração do DNA para trabalho $(3 \mathrm{ng} / \mu \mathrm{L})$.

$\mathrm{V}_{2}=$ Volume estipulado de DNA para trabalho $(200 \mu \mathrm{L})$. 
FACULDADE DE AGRONOMIA E MEDICINA VETERINÁRIA

Programa de Pós Graduação em Agronomia

O DNA diluído foi quantificado em gel de agarose $1 \%$ utilizando DNA $\lambda$ com concentração de 15, 30 e $50 \mathrm{ng}$ (total) como comparativo e os ajustes e requantificação foram feitos quantas vezes necessário até a obtenção da concentração de $3 \mathrm{ng} / \mu \mathrm{L}$. A visualização das bandas decorrentes da quantificação foi realizada por leitura da intensidade de fluorescência do brometo de etídeo sob luz ultravioleta (UV) em transiluminador e fotografada em fotodocumentador. O brometo de etídeo é um corante que se intercala nas moléculas dos ácidos nucléicos sendo que a luz ultravioleta induz a fluroscência.

\subsection{Reações e amplificação da PCR}

Para a realização das reações de PCR, tanto para marcadores SSR quanto para marcadores ISSR, foram utilizados $3 \mu \mathrm{L}$ de DNA a aproximadamente $3 \mathrm{ng} ; 3 \mu \mathrm{L}$ de primer (oligonucleotídeos desenhados para serem complementares à sequência alvo) a 0,9 $\mu \mathrm{M}$ para marcadores SSR e 1,2 $\mu \mathrm{M}$ para marcadores ISSR; e $7 \mu \mathrm{L}$ de mix totalizando $13 \mu \mathrm{L}$ de reação.

\section{Marcadores SSR}

Os primers SSR que foram utilizados para as reações foram desenvolvidos por Ritschel et al., (2004) e Ohse et al., (2005). Foram testados e otimizados em "pré-seleção" ou screnning (com número de genótipos reduzido) 294 primers para os genótipos Pele de Sapo, 293 para os genótipos Amarelo e 287 para os genótipos Cantaloupe.

Os primers $\mathrm{F}$ e $\mathrm{R}$ (forward e reverse) foram utilizados, de acordo com a ocorrência de polimorfismos, para reações com todos os genótipos, diluídos em água à 0,9 $\mu \mathrm{M}$. Para tanto, ambos $(\mathrm{F}+\mathrm{R})$ foram diluídos em TE pH 8,0 (Tris-EDTA) à $100 \mu \mathrm{M}$. Na Tabela 3 encontram-se os primers SSR polimórficos com suas respectivas sequências (forward e reverse) e temperaturas de anelamento otimizadas, utilizados para as reações com os genótipos dos três tipos de melão analisados nesse estudo. 
FACULDADE DE AGRONOMIA E MEDICINA VETERINÁRIA

Programa de Pós Graduação em Agronomia

Tabela 3: Lista com as sequências (forward e reverse) e temperaturas de anelamento otimizadas dos primers SSR polimórficos utilizados para as reações com os genótipos dos três tipos de melão analisados.

\begin{tabular}{|c|c|c|}
\hline $\begin{array}{l}\text { Marcador } \\
\quad \text { SSR }\end{array}$ & Sequência forward e reverse & $\begin{array}{c}\text { Temperatura } \\
\text { de } \\
\text { Anelamento }\end{array}$ \\
\hline CM1 & $\begin{array}{l}\text { F5'-AGATGACCAAACCAAACCCA-3' } \\
\text { R5'-CAACGTTATGGGGATGAAGG-3' }\end{array}$ & $56^{\circ} \mathrm{C}$ \\
\hline CM2 & $\begin{array}{l}\text { F5'-TGCAAATATTGTGAAGGCGA-3' } \\
\text { R5'-AATCCCCACTTGTTGGTTTG-3' }\end{array}$ & $60^{\circ} \mathrm{C}$ \\
\hline CM12 & $\begin{array}{l}\text { F 5'-AACAAACATGGAAATAGCTTTCA-3' } \\
\text { R5'-GCCTTTTGTGATGCTCCAAT-3' }\end{array}$ & $60^{\circ} \mathrm{C}$ \\
\hline CM14 & $\begin{array}{l}\mathbf{F} 5 \text { '-CCATTCTTTACTCTCTCTGAAACCA-3' } \\
\mathbf{R} 5 \text { '-TCACAАТСТСТСССТАСCAAGAA-3' }\end{array}$ & $58^{\circ} \mathrm{C}$ \\
\hline CM15 & $\begin{array}{l}\text { F5'-TATGAAGCGCGCATAAACAG-3', } \\
\text { R5'-CGAATGTGAAATCTCTTCTCCC-3' }\end{array}$ & $58^{\circ} \mathrm{C}$ \\
\hline CM21 & $\begin{array}{l}\text { F5'-AGATTCTGGTTGTTGGGCAG-3', } \\
\text { R5' -CAGCGATGATCAACAGAAACA-3' }\end{array}$ & $59^{\circ} \mathrm{C}$ \\
\hline CM25 & $\begin{array}{l}\text { F5' - TGGGGTTGTCAATACAGCAA } \\
\text { R5'-GGAGTGCGTGGAATGTACG-3' }\end{array}$ & $58^{\circ} \mathrm{C}$ \\
\hline CM27 & $\begin{array}{l}\text { F5'-AAACAAACATGGAAATAGCTTTCA-3' } \\
\text { R5' -TAGTTGGGTGGGCTAAAGGA-3' }\end{array}$ & $58^{\circ} \mathrm{C}$ \\
\hline CM33 & $\begin{array}{l}\mathbf{F 5} 5^{\prime} \text {-TGATCATCTACTTTTACACCATTCTTT-3' } \\
\text { R5' }{ }^{\prime} \text {-TCACAАTCTCTCCCTACCAAGA-3' }\end{array}$ & $58^{\circ} \mathrm{C}$ \\
\hline CM34 & $\begin{array}{l}\text { F5'-TCTCTTTGTTTCCTCCCCCT-3' } \\
\text { R5' -GTGGGGCTTGGTTCTTTTG-3' }\end{array}$ & $54^{\circ} \mathrm{C}$ \\
\hline CM35 & $\begin{array}{l}\text { F5'-GGGTATTATTTGCCCCACCT-3' } \\
\text { R5'-TGAAGAATAGGGATGAGTGTGAGA-3' }\end{array}$ & $56^{\circ} \mathrm{C}$ \\
\hline CM40 & $\begin{array}{l}\text { F5'-CGACAATCACGGGAGAGTTT-3' } \\
\text { R5'-TTGTTGCATCAAACTAACACAATC-3' }\end{array}$ & $56^{\circ} \mathrm{C}$ \\
\hline CM43 & $\begin{array}{l}\text { F5'-AGAGATGCTCCCTACACTGC-3' } \\
\text { R5'-TCAAGCAAACCCTAATCGGT-3' }\end{array}$ & $56^{\circ} \mathrm{C}$ \\
\hline
\end{tabular}


FACULDADE DE AGRONOMIA E MEDICINA VETERINÁRIA

Programa de Pós Graduação em Agronomia

\begin{tabular}{|c|c|c|}
\hline $\begin{array}{l}\text { Marcador } \\
\quad \text { SSR }\end{array}$ & Sequência forward e reverse & $\begin{array}{l}\text { Temperatura } \\
\text { de } \\
\text { Anelamento }\end{array}$ \\
\hline CM51 & $\begin{array}{l}\text { F5'-CGACAATCACGGGAGAGTTT-3' } \\
\text { R5'-TTGTTGCATCAAACTAACACAATC-3' }\end{array}$ & $58^{\circ} \mathrm{C}$ \\
\hline CM64 & $\begin{array}{l}\text { F5'-ATACAGCAGATCCACAGGGG-3' } \\
\text { R5'-ATGGGAGTGTGTGGGATGTA-3' }\end{array}$ & $54^{\circ} \mathrm{C}$ \\
\hline CM72 & $\begin{array}{l}\text { F5'-GGTATTATTTGCCCCCACCT-3' } \\
\text { R5'-TGAAGAGTAGGGATGAGTGTGAGA-3' }\end{array}$ & $58^{\circ} \mathrm{C}$ \\
\hline CM83 & $\begin{array}{l}\text { F5'-CGGACAAATCCCTCTCTGAA-3' } \\
\text { R5'-GAACAAGCAGCCAAAGACG-3' }\end{array}$ & $56^{\circ} \mathrm{C}$ \\
\hline CM87 & $\begin{array}{l}\text { F5'-TCCACCCAGACTCATCTCATC-3' } \\
\text { R5'-TGTGGTTTTTGTGAGCCAGA-3' }\end{array}$ & $56^{\circ} \mathrm{C}$ \\
\hline CM89 & $\begin{array}{l}\text { F5'-TCATCTCATTCTCATTCTTCCTCT-3' } \\
\text { R5'-TGAGGTTTATGAGTGTGTGGTTTT-3' }\end{array}$ & $58^{\circ} \mathrm{C}$ \\
\hline CM90 & $\begin{array}{l}\text { F5'-GTACCTCCGCCGTTGATCT-3' } \\
\text { R5'-TGAGATAATAAGAAATCCAACCCA-3' }\end{array}$ & $56^{\circ} \mathrm{C}$ \\
\hline CM93 & $\begin{array}{l}\text { F5'-CCACGTAAAGAACGCTTTGG-3' } \\
\text { R5'-GTCGGAAACTTGAAGCCTTG-3' }\end{array}$ & $56^{\circ} \mathrm{C}$ \\
\hline CM95 & $\begin{array}{l}\text { F5'-TTGACCTTTTACGGTGGTCC-3' } \\
\text { R5'-CGGACAAATCCCTCTCTGAA-3' }\end{array}$ & $56^{\circ} \mathrm{C}$ \\
\hline CM102 & $\begin{array}{l}\text { F5'-GGGAGCCCCTCATTTTCTC-3' } \\
\text { R5'-TTTTCAACCAACATCCACCC-3' }\end{array}$ & $60^{\circ} \mathrm{C}$ \\
\hline CM104 & $\begin{array}{l}\text { F5'-CAAAAGGAAAAGAAAAAGACCAAA-3' } \\
\text { R5'-GGTATTATTTGCCCCCACCT-3' }\end{array}$ & $59^{\circ} \mathrm{C}$ \\
\hline CM105 & $\begin{array}{l}\text { F5'-TGGTAAGCATTTTGAAATCACTTTT-3' } \\
\text { R5'-TTTGTATGGTTGGAGGGGAA-3' }\end{array}$ & $56^{\circ} \mathrm{C}$ \\
\hline CM106 & $\begin{array}{l}\text { F5'-GTACCTCCGCCGTTGATCT-3' } \\
\text { R5'-TGAGATAATAAGAAATCCAACCCA-3' }\end{array}$ & $56^{\circ} \mathrm{C}$ \\
\hline CM107 & $\begin{array}{l}\text { F5'-TATGAAGCGCGCATAAACAG-3' } \\
\text { R5'-CGAATGTGAAATCTCTTCTCCC-3' }\end{array}$ & $56^{\circ} \mathrm{C}$ \\
\hline CM112 & $\begin{array}{l}\text { F5'-TGTACTCCACCAGCAAACATC-3' } \\
\text { R5'-TGATGCGTGTATGCCTAGAAA-3' }\end{array}$ & $54^{\circ} \mathrm{C}$ \\
\hline
\end{tabular}


FACULDADE DE AGRONOMIA E MEDICINA VETERINÁRIA

Programa de Pós Graduação em Agronomia

\begin{tabular}{|c|c|c|}
\hline $\begin{array}{l}\text { Marcador } \\
\quad \text { SSR }\end{array}$ & Sequência forward e reverse & $\begin{array}{c}\text { Temperatura } \\
\text { de } \\
\text { Anelamento }\end{array}$ \\
\hline CM123 & $\begin{array}{l}\text { F5'-GGATTGGCTGCTGCTTTT-3' } \\
\text { R5'-GCTATGCGATGAGATTCCTATG-3' }\end{array}$ & $54^{\circ} \mathrm{C}$ \\
\hline CM125 & $\begin{array}{l}\text { F5'-CTTCTCTCTCAATGCATAACCA-3' } \\
\text { R5'-AACCCAGAAGGAGAAGTACAA-3' }\end{array}$ & $54^{\circ} \mathrm{C}$ \\
\hline CM140 & $\begin{array}{l}\text { F5'-CCCNGTCAAATCCGCTATT-3' } \\
\text { R5'-TGATGCACATACCAAAAACGA-3' }\end{array}$ & $56^{\circ} \mathrm{C}$ \\
\hline CM152 & $\begin{array}{l}\text { F5'-TCCCTCCCCTTCTTTGATTC-3' } \\
\text { R5'-CACTGTGGCGCTAAACAAAA-3' }\end{array}$ & $54^{\circ} \mathrm{C}$ \\
\hline M161 & $\begin{array}{l}\text { F5'-GCGCAAACCACAGAGAAGAT-3' } \\
\text { R5'-GCATAGGGAACTTGCCAGAG-3' }\end{array}$ & $56^{\circ} \mathrm{C}$ \\
\hline CM165 & $\begin{array}{l}\text { F5'-CATGGAACAATGAGTTCAAAGG-3' } \\
\text { R5'-AAGTAATGGGACCCACCTGA-3' }\end{array}$ & $56^{\circ} \mathrm{C}$ \\
\hline M168 & $\begin{array}{l}\text { F5'-GAGACACGGAGAGAATGAGGTT-3' } \\
\text { R5'-ATCCACCCAGACACATCTCA-3' }\end{array}$ & $56^{\circ} \mathrm{C}$ \\
\hline M171 & $\begin{array}{l}\text { F5'-CCAAATACGACCAAATGTTCC-3' } \\
\text { R5'-AGTTCTTCCAGTCAACAAAATA-3' }\end{array}$ & $56^{\circ} \mathrm{C}$ \\
\hline CM173 & $\begin{array}{l}\text { F5'-AACTAAGAGTTTGCATTGATCCTC-3' } \\
\text { R5'-GCTCCATATCCCATTGATTTC-3' }\end{array}$ & $56^{\circ} \mathrm{C}$ \\
\hline CM174 & $\begin{array}{l}\text { F5'-ATTGGTGGTTTTTGCAGGAG-3' } \\
\text { R5'-ACATTTTGAGCGGGGTTTTA-3' }\end{array}$ & $56^{\circ} \mathrm{C}$ \\
\hline CM176 & $\begin{array}{l}\text { F5'-TCACCAAACCCTAACACACAA-3' } \\
\text { R5'-TGGGGATATTCGGATGAAAA-3' }\end{array}$ & $56^{\circ} \mathrm{C}$ \\
\hline M177 & $\begin{array}{l}\text { F5'-TGGAATGAAATGATTGAGAGGTT-3' } \\
\text { R5'-ATCTCCCTATCCCCACCATA-3' }\end{array}$ & $56^{\circ} \mathrm{C}$ \\
\hline CM185 & $\begin{array}{l}\text { F5'-GCTTTTGCTCTATTTTCTTCTTCTT-3' } \\
\text { R5'-GGCTTGGTAACCGAAGATCC-3' }\end{array}$ & $56^{\circ} \mathrm{C}$ \\
\hline CM186 & $\begin{array}{l}\text { F5'-TTTTTCTTTATACCTATTTCCACTCAC-3' } \\
\text { R5'-GGAATAAACTTGGTTGAAAAATATAA-3' }\end{array}$ & $56^{\circ} \mathrm{C}$ \\
\hline
\end{tabular}


FACULDADE DE AGRONOMIA E MEDICINA VETERINÁRIA

Programa de Pós Graduação em Agronomia

\begin{tabular}{|c|c|c|}
\hline $\begin{array}{l}\text { Marcador } \\
\text { SSR }\end{array}$ & Sequência forward e reverse & $\begin{array}{c}\text { Temperatura } \\
\text { de } \\
\text { Anelamento }\end{array}$ \\
\hline CM190 & $\begin{array}{l}\text { F5'-GTACCTCCGCCGTTGATCT-3' } \\
\text { R5'-CCACATGAGATAATAAGAAATCCA-3' }\end{array}$ & $56^{\circ} \mathrm{C}$ \\
\hline CM191 & $\begin{array}{l}\text { F5'-AACTATCCAAGAAATCCCCACTT-3' } \\
\text { R5'-TAATATGTGGAAAGGGAAATGC-3' }\end{array}$ & $56^{\circ} \mathrm{C}$ \\
\hline CM197 & $\begin{array}{l}\text { F5'-TGACATCCACCCAGACTCAT-3' } \\
\text { R5'-CAGAGACACGAAGAGAAAGAGG-3' }\end{array}$ & $56^{\circ} \mathrm{C}$ \\
\hline CM218 & $\begin{array}{l}\text { F5'-TTGAGTTTTGTCTCACTTTGCAG-3' } \\
\text { R5'-CGGCGATTCCTAGTACTAAAACTTA-3' }\end{array}$ & $56^{\circ} \mathrm{C}$ \\
\hline CM224 & $\begin{array}{l}\text { F5'-AAGAGAGCTTTCGCCTGTTC-3' } \\
\text { R5'-GAGATTTGCAAGTCGAAAAAA-3' }\end{array}$ & $56^{\circ} \mathrm{C}$ \\
\hline CM225 & $\begin{array}{l}\text { F5'-AATGAGTTTGACTATTTTAGGAGCAAG-3' } \\
\text { R5'-CAACAGATAAAATATTCCCCCTCA-3' }\end{array}$ & $56^{\circ} \mathrm{C}$ \\
\hline CM227 & $\begin{array}{l}\text { F5'-AGAGACCTCTCCCACCCATT-3' } \\
\text { R5'-CGGTCTTCTTTGTTGTAAGTTGT-3' }\end{array}$ & $56^{\circ} \mathrm{C}$ \\
\hline CM228 & $\begin{array}{l}\text { F5'-AACAAGGAACAGTCGGCTTG-3' } \\
\text { R5'-CTCCCATAGACAACCGATTT-3' }\end{array}$ & $56^{\circ} \mathrm{C}$ \\
\hline CM230 & $\begin{array}{l}\text { F5'-ACACAAGACGTCTCAGAACTGC-3' } \\
\text { R5'-CAAAAAGCATCAAAATGGTTG-3' }\end{array}$ & $56^{\circ} \mathrm{C}$ \\
\hline CM244 & $\begin{array}{l}\text { F5'-CAGCAGATGACCAAACCAAA-3' } \\
\text { R5'-CGTTATGAGGATAAGGGAGAAA-3' }\end{array}$ & $56^{\circ} \mathrm{C}$ \\
\hline CM247 & $\begin{array}{l}\text { F5'-ATGATGTAACGTTAGCCTGATCC-3' } \\
\text { R5'-AGTGGGAATCTTCTCAACTTGG-3' }\end{array}$ & $56^{\circ} \mathrm{C}$ \\
\hline CM248 & $\begin{array}{l}\text { F5'-CCACCTCTCTCAATGTAAGCA-3' } \\
\text { R5'-GGTCCAGACCAGAAACAAAA-3' }\end{array}$ & $56^{\circ} \mathrm{C}$ \\
\hline CM253 & $\begin{array}{l}\text { F5'-AAGCTTCTCCGCTATGGTCA-3' } \\
\text { R5'-AGTGGAGAACAGAGGCCAGA-3' }\end{array}$ & $56^{\circ} \mathrm{C}$ \\
\hline CM254 & $\begin{array}{l}\text { F5'-TACAGACACGCCTTCACCTG-3' } \\
\text { R5'-ACCAAATACGCCCAAATGTT-3' }\end{array}$ & $56^{\circ} \mathrm{C}$ \\
\hline CM302 & $\begin{array}{l}\text { F5'-AACGAATGCTGAAGCTGTTG-3' } \\
\text { R5'-GGATAATGTCACCATAGTAAAACCAA-3' }\end{array}$ & $56^{\circ} \mathrm{C}$ \\
\hline
\end{tabular}


FACULDADE DE AGRONOMIA E MEDICINA VETERINÁRIA

Programa de Pós Graduação em Agronomia

\begin{tabular}{|c|c|c|}
\hline $\begin{array}{l}\text { Marcador } \\
\text { SSR }\end{array}$ & Sequência forward e reverse & $\begin{array}{c}\text { Temperatura } \\
\text { de } \\
\text { Anelamento }\end{array}$ \\
\hline CM303 & $\begin{array}{l}\text { F5'-CTGCAAGTGCGGTGACAACT-3' } \\
\text { R5'-TCGAACACAATCTCCACTTAAGAA-3' }\end{array}$ & $56^{\circ} \mathrm{C}$ \\
\hline CM305 & $\begin{array}{l}\text { F5'-GCAAACCCACCAAATTTCC-3' } \\
\text { R5'-AGAACATGGAATTGGGAATCG-3' }\end{array}$ & $56^{\circ} \mathrm{C}$ \\
\hline CM306 & $\begin{array}{l}\text { F5'-CCGCATATGATGAAGACGAA-3' } \\
\text { R5'-TTGTTCTTCTTGTACCGATTTCAA-3' }\end{array}$ & $56^{\circ} \mathrm{C}$ \\
\hline CM307 & $\begin{array}{l}\text { F5'-TTGAGTTTGAGATAAGAGTAAGAAAA-3' } \\
\text { R5'-TCTCATCCTCCAAACCTTCTTC-3' }\end{array}$ & $56^{\circ} \mathrm{C}$ \\
\hline CM311 & $\begin{array}{l}\text { F5'-GACTCAACAAACCCATCAAAAA-3' } \\
\text { R5'-AGTTTGTCGTCGTCGGGAAT-3' }\end{array}$ & $56^{\circ} \mathrm{C}$ \\
\hline CM312 & $\begin{array}{l}\text { F5'-TGTTTCGTCATCACCTTCTTCTT-3' } \\
\text { R5'-GGTGATGGTATTTGAGGTTGAGA-3' }\end{array}$ & $56^{\circ} \mathrm{C}$ \\
\hline CM317 & $\begin{array}{l}\text { F5'-CTTAGGGTTTTAGCGCATTCC-3' } \\
\text { R5'-TAGTAATGGCGAGGGGACGA-3' }\end{array}$ & $56^{\circ} \mathrm{C}$ \\
\hline CM319 & $\begin{array}{l}\text { F5'-AAGATGGAGATGAGTTGGCAAT-3' } \\
\text { R5'-GAGCTCAATGTTCCTATTGGTTT-3' }\end{array}$ & $56^{\circ} \mathrm{C}$ \\
\hline CM320 & $\begin{array}{l}\text { F5'-TGGAGAAAGAAAAACTGAGCTG-3' } \\
\text { R5'-GAACCCCATAAACACATCCAA-3' }\end{array}$ & $56^{\circ} \mathrm{C}$ \\
\hline CM321 & $\begin{array}{l}\text { F5'-GGCGTTTCTCTCTGGTTTCA-3' } \\
\text { R5'-CTAAGCCTCGGACTCCTCAA-3' }\end{array}$ & $56^{\circ} \mathrm{C}$ \\
\hline CM324 & $\begin{array}{l}\text { F5'-CCTTTAAACCGACTCAAAATCC-3' } \\
\text { R5'-ACCAGACAGTCGTTCCGAAG-3' }\end{array}$ & $56^{\circ} \mathrm{C}$ \\
\hline CM326 & $\begin{array}{l}\text { F5'-CCGGAGGTCAGGTAGTCGTA-3' } \\
\text { R5'-CTAAACGGATTCGCCAACTT-3' }\end{array}$ & $56^{\circ} \mathrm{C}$ \\
\hline CM330 & $\begin{array}{l}\text { F5'-TTTCCAAGTTTTTGCGCATT-3' } \\
\text { R5'-TAAGAGGATGGTCACAAATCG-3' }\end{array}$ & $56^{\circ} \mathrm{C}$ \\
\hline CM331 & $\begin{array}{l}\text { F5'-CAACATCAAGCATCAGAAGCA-3' } \\
\text { R5'-AAACTTAAGCTTCCAACCTCCT-3' }\end{array}$ & $56^{\circ} \mathrm{C}$ \\
\hline
\end{tabular}


FACULDADE DE AGRONOMIA E MEDICINA VETERINÁRIA

Programa de Pós Graduação em Agronomia

\begin{tabular}{clc}
$\begin{array}{c}\text { Marcador } \\
\text { SSR }\end{array}$ & \multicolumn{1}{c}{$\begin{array}{c}\text { Sequência forward e reverse } \\
\text { CM336 }\end{array}$} & $\begin{array}{c}\text { Temperatura } \\
\text { de } \\
\text { R5'-CCAAATCTCTCCCCCACATA-3' } \\
\text { Anelamento }\end{array}$ \\
\hline CM342 & F5'-TTCCATTAATCATCTCCTCCAAA-3' & $56^{\circ} \mathrm{C}$ \\
& R5'-CTCAGTGTAAGTTGCTGGGAAA-3' & $56^{\circ} \mathrm{C}$ \\
CM347 & F5'-CTCCACTTCTAAACTCTAAATGAAAT-3' & \\
& R5'-AACCTCTAAACATAAAATGACAATGA-3' & \\
CM354 & F5'-TTCCATTAATCATCTCCTCCAAA-3' & \\
& R5'-CTCAGTGTAAGTTGCTGGGAAA-3' & $56^{\circ} \mathrm{C}$ \\
\hline
\end{tabular}

Para as reações de PCR, foi utilizado o mix de reagentes a seguir: 2,65 $\mu \mathrm{L}$ de água; $1,30 \mu \mathrm{L}$ de dNTP a 2,5 $\mu \mathrm{M} ; 1,30 \mu \mathrm{L}$ de BSA a $2,5 \mathrm{ng} / \mathrm{mL} ; 1,30 \mu \mathrm{L}$ de tampão $10 \mathrm{x}$ contendo $100 \mu \mathrm{M}$ Tris- $\mathrm{HCl} \mathrm{pH} 8,3 ; 500 \mu \mathrm{M} \mathrm{KCl} ; 0,25 \mu \mathrm{L}$ de $\mathrm{MgCl}_{2} 50 \mu \mathrm{M}$ e 0,20 $\mu \mathrm{L}$ de Taq DNA polimerase a 5,0 U/ $\mu \mathrm{L}$.

As condições de amplificação foram as seguintes: Um ciclo inicial de 5 minutos a $94^{\circ} \mathrm{C}$, seguido de 30 ciclos de 1 minuto a $94^{\circ} \mathrm{C}, 1$ minuto na temperatura de anelamento (otimizada para cada primer - Variando de 52 a $60^{\circ} \mathrm{C}$ ), e 1 minuto a $72^{\circ} \mathrm{C}$, seguidos de um ciclo final de 10 minutos a $72^{\circ} \mathrm{C}$.

A separação dos fragmentos obtidos a partir de PCR foi realizada por meio de eletroforese vertical em gel de poliacrilamida 5\%, coloração com nitrato de prata $\left(\mathrm{AgNO}_{3}\right)$ e revelação com carbonato de sódio anidro $\left(\mathrm{Na}_{2} \mathrm{CO}_{3}\right)$, a uma constante de $90 \mathrm{~W}$ de potência. $\mathrm{O}$ gel de poliacrilamida 5\% é constituído por uma malha que separa fragmentos entre 2 a 4 pb, menores se comparado ao gel de agarose. Dessa forma, como os tamanhos dos fragmentos se mostraram muito próximos, optou-se por utilizar a eletroforese em gel de poliacrilamida 5\%, devido à sensibilidade e especificidade na separação de macromoléculas. O tamanho dos fragmentos amplificados em pares de base foi avaliado por comparação com marcador de peso molecular: Ladder 10pb. 
FACULDADE DE AGRONOMIA E MEDICINA VETERINÁRIA

Programa de Pós Graduação em Agronomia

\section{$\underline{\text { Marcadores ISSR }}$}

Os marcadores ISSR foram utilizados apenas para os genótipos Pele de Sapo, devido à dificuldade de ocorrência de polimorfismos nesses. Foram selecionados 35 primers, sendo 24 desenhados para milho (Zea mays L.) (GIANFILIPPI, 2006) e 11 para feijão (Phaseolus vulgaris L.) (ACAMPORA et al., 2007), que foram "pré-selecionados" e utilizados de acordo com a ocorrência de polimorfismos para reações com todos os genótipos. Os primers foram utilizados diluídos em água à 1,2 $\mu \mathrm{M}$. Para tanto, os mesmos foram diluídos em TE pH 8,0 (Tris-EDTA) à $100 \mu \mathrm{M}$.

Para as reações de PCR com marcadores ISSR, foi utilizado o mix de reagentes a seguir: $2,59 \mu \mathrm{L}$ de água; $1,30 \mu \mathrm{L}$ de dNTP a 2,5 $\mu \mathrm{M} ; 1,30 \mu \mathrm{L}$ de BSA a 2,5 ng/mL; 1,30 $\mu \mathrm{L}$ de tampão 10x contendo $100 \mu \mathrm{M}$ Tris- $\mathrm{HCl} \mathrm{pH} 8,3 ; 500 \mu \mathrm{M} \mathrm{KCl} ; 0,25 \mu \mathrm{L}$ de $\mathrm{MgCl}_{2} 50 \mathrm{mM}$ e $0,26 \mu \mathrm{L}$ de Taq DNA polimerase a 5,0 U/ $\mu \mathrm{L}$.

As condições de amplificação foram as seguintes: Um ciclo inicial de 5 minutos a $94^{\circ} \mathrm{C}$, seguido de 35 ciclos de 45 segundos a $94^{\circ} \mathrm{C}, 1$ minuto na temperatura de anelamento $\left(56^{\circ} \mathrm{C}\right.$ estabelecida para todos os primers), e 1 minuto e meio a $72^{\circ} \mathrm{C}$, seguidos de um ciclo final de 7 minutos a $72^{\circ} \mathrm{C}$.

A separação dos fragmentos obtidos a partir de PCR foi realizada por meio de eletroforese horizontal em gel de agarose $1,5 \%$.

2.5 Análise estatística dos marcadores gerados

Para marcadores ISSR, os dados obtidos foram computados no software NTSYS (ROHLF, 1992), que forneceu estimadores de similaridade genética e agrupamento, por meio da análise dos genótipos.

O primeiro passo para a análise dos marcadores obtidos foi a codificação dos fragmentos moleculares em dados binários, comumente realizado no caso de marcadores 
FACULDADE DE AGRONOMIA E MEDICINA VETERINÁRIA

Programa de Pós Graduação em Agronomia

dominantes, como é o caso do ISSR. Os dados foram codificados como: 1 (presença do marcador) ou 0 (ausência do marcador).

O segundo passo compreendeu a utilização dos dados codificados para a estimativa de índices de similaridade entre cada par de acessos. Vários índices são descritos na literatura, mas o coeficiente de Jaccard foi o usado nesse estudo. Com base nos índices, estabeleceu-se uma matriz de similaridade entre os acessos que serviu de base para as análises de agrupamento e de dispersão dos mesmos (FALEIRO, 2007).

A análise de agrupamento é baseada em método hierárquico que utiliza o critério das médias das distâncias entre o vizinho mais próximo (single linkage) e o mais distante (complete linkage). Esse método é conhecido como Unweighted Pair-group Method Using Arithmetic Average ou simplesmente, Método da Ligação Média entre Grupos (UPGMA). Após essa análise, o programa gera o dendrograma dos genótipos analisados, onde se visualizam agrupamentos dos mesmos por similaridade (FALEIRO, 2007).

Os dados para marcadores codominantes, como é o caso dos microssatélites, foram codificados na forma $\mathrm{x} / \mathrm{y}$ (tamanho de cada alelo no loco) e os dados obtidos foram analisados por meio do uso de softwares específicos para análise genética: GDA (LEWIS \& ZAYKIN, 2001), que forneceu dados como o número de genótipos observados em cada loco (n), o número de alelos por loco (A), heterozigosidade observada (Ho), e heterozigosidade esperada (He) ou Polymorphism Information Content (PIC) (o PIC no software GDA é estimado sem a constante do estimador, ou seja, corresponde à He neste trabalho), e o índice de fixação WRIGHT (1965) ou coeficiente de endogamia (f), que representa a proporção de homozigotos na população e é estimado com base na Ho e He, sendo 1-(Ho/He). Quanto mais próximo de 1 ( $\mathrm{f}>0$ ) for a média, haverá excesso de homozigotos na população,ou seja, maior será a taxa de endogamia; Com $\mathrm{f}<0$, há excesso de heterozigotos, e com $\mathrm{f}=0$, a população estará em equilíbrio de Hardy-Weinberg.

A heterozigosidade de um marcador é a probabilidade de um indivíduo ser heterozigoto no loco marcador e depende do número de alelos no loco e de sua frequência na 
FACULDADE DE AGRONOMIA E MEIDICINA VETERINÁRIA

Programa de Pós Graduação em Agronomia

população. A Ho foi calculada utilizando-se a proporção entre os genótipos heterozigotos individuais e o número total de heterozigotos analisados em cada loco, sendo que, quanto mais próximo de zero, maior será a proporção de locos em homozigose. A He foi estimada com base na probabilidade de dois indivíduos tomados ao acaso, em uma dada amostra apresentarem alelos diferentes em um loco (NEI, 1987). O PIC trata-se de um estimador que reflete tanto o número de alelos como a frequência de cada alelo, e será maior quanto maior for o número de alelos. Com esse estimador, o PIC torna-se sinônimo de heterozigosidade (ROBINSON, 1998) e diversidade genética (SENIOR et al., 1998); e NTSYS (ROHLF, 1992), que forneceu estimadores de similaridade genética e agrupamento por meio do uso do coeficiente BAND (Band-Sharing Coefficient of Lynch) (LYNCH, 1990) e do método UPGMA. O coeficiente BAND é baseado na soma da proporção de alelos comuns entre dois genótipos dividida pelo dobro do número de alelos testados.

\section{RESULTADOS E DISCUSSÃO}

3.1 Genótipos do melão tipo Pele de Sapo

\section{$\underline{\text { SSR }}$}

Foram pré selecionados em screnning 294 primers para os genótipos Pele de Sapo. Destes, 103 não amplificaram, 156 foram monomórficos (não apresentaram alelos diferentes entre os genótipos) e 35 foram polimórficos. Foram analisados apenas 18 dos 35 locos polimórficos, por apresentarem bandas bem definidas e mais nítidas (Figura 2).

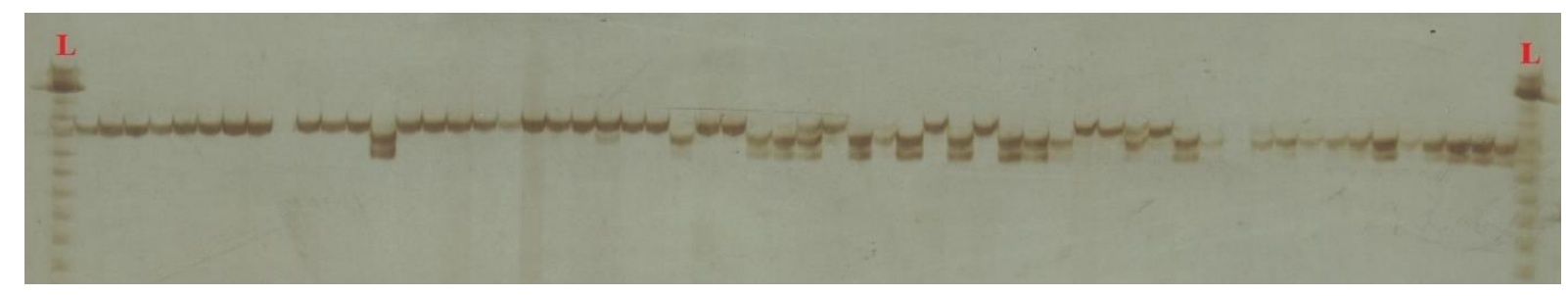

Figura 2: Primer CM102 - Um dos 18 primers SSR polimórficos para os 58 genótipos Pele de Sapo. L: Primeira e última coluna: Marcador de peso molecular Ladder 10pb. 
FACULDADE DE AGRONOMIA E MEDICINA VETERINÁRIA

Programa de Pós Graduação em Agronomia

Os 18 locos analisados para os 58 genótipos Pele de Sapo amplificaram 45 alelos com média de 2,5 alelos por loco (Tabela 4), número maior de alelos do que o descrito por Szabó et al., (2005), que avaliaram 47 acessos de melão utilizando 8 primers SSR polimórficos, e amplificaram 40 alelos. Número de alelos e média também superiores aos descritos por Aragão (2011), que avaliou 41 acessos de melão utilizando 17 primers, também desenvolvidos por Ritschel et al., (2004), e amplificou 41 alelos com média de 2,41 alelos por loco.

No trabalho de Tzuri et al., (2006), os 48 marcadores SSR usados amplificaram em todos os 102 genótipos avaliados. Os autores comentam que devido ao alto nível de polimorfismo detectado, que os marcadores SSR são promissores na estimativa de variação genética em melão.

A He/PIC variou de 0,034 nos locos CM320 e CM311 a 0,525 no loco CM107 (Tabela 4). De acordo com Botstein et al., (1980), o PIC também é indicativo da qualidade do marcador em estudos genéticos. PIC superiores a 0,5 são considerados muito informativos, com valores entre 0,25 e 0,50 mediamente informativos e com valores inferiores a 0,25, pouco informativos. Dessa forma, o PIC se apresentou medianamente informativo para os locos em questão, apresentando média de 0,334. A frequência do alelo principal de cada loco será maior, quão menor for o valor do PIC, assim sendo, os locos CM320 e CM311 apresentaram maior frequência do alelo principal sendo pouco informativos e o loco CM107 apresentou um maior número de alelos, sendo o loco mais informativo.

Ainda a respeito do PIC, Lopez Sesé et al., (2002) observaram que os valores de PIC tenderam aos valores da diversidade genética na medida em que o número de alelos de um loco SSR aumentou e Aragão (2011) afirmou que o poder discriminatório do marcador está associado tanto com a frequência quanto com o número de alelos do mesmo, o que não pôde ser observado neste trabalho, já que o loco CM102 apresentou apenas 2 alelos e o terceiro maior valor de PIC $(0,500)$ (Tabela 4$)$. 


\section{FACULDADE DE AGRONOMIA E MEDICINA VETERINÁRIA}

\section{Programa de Pós Graduação em Agronomia}

A Ho, que representa a proporção de indivíduos heterozigotos para o loco em questão, apresentou muitos locos em homozigose com valores de zero absoluto e média de 0,011. O baixo índice de Ho observado condiz com o esperado, já que trata-se da análise de linhagens parcialmente endogâmicas (Tabela 4).

$\mathrm{O}$ coeficiente de endogamia (f) variou de $-0,08$ no loco CM311, indicando um excesso de heterozigotos para este loco, a 1 na maioria dos locos, indicando alta taxa de endogamia. O valor médio de f foi de 0,965 , também muito próximo de 1 , indicando alta taxa de endogamia (Tabela 4).

Tabela4: Medidas descritivas para estudos de variabilidade baseados nos marcadores SSR polimórficos em 58 genótipos de melão do tipo Pele de Sapo, estimados pelo software GDA.

\begin{tabular}{cccccc}
\hline Loco & N & A & He/PIC & Ho & f \\
\hline CM197 & 58 & 3 & 0,464 & 0,068 & 0,852 \\
CM191 & 56 & 3 & 0,427 & 0,000 & 1,000 \\
CM302 & 58 & 2 & 0,287 & 0,000 & 1,000 \\
CM320 & 58 & 2 & 0,034 & 0,000 & 1,000 \\
CM104 & 56 & 2 & 0,247 & 0,000 & 1,000 \\
CM152 & 54 & 2 & 0,442 & 0,018 & 0,958 \\
CM331 & 56 & 3 & 0,436 & 0,000 & 1,000 \\
CM311 & 58 & 2 & 0,034 & 0,034 & $-0,008$ \\
CM15 & 57 & 2 & 0,478 & 0,000 & 1,000 \\
M177 & 47 & 3 & 0,463 & 0,000 & 1,000 \\
CM224 & 56 & 3 & 0,069 & 0,017 & 0,746 \\
CM35 & 34 & 2 & 0,365 & 0,000 & 1,000 \\
CM319 & 56 & 2 & 0,504 & 0,017 & 0,964 \\
CM72 & 42 & 2 & 0,312 & 0,000 & 1,000 \\
CM107 & 52 & 5 & 0,525 & 0,000 & 1,000 \\
CM102 & 58 & 2 & 0,500 & 0,051 & 0,897 \\
CM89 & 56 & 3 & 0,196 & 0,000 & 1,000
\end{tabular}


FACULDADE DE AGRONOMIA E MEDICINA VETERINÁRIA

Programa de Pós Graduação em Agronomia

\begin{tabular}{cccccc} 
Loco & $\mathbf{N}$ & $\mathbf{A}$ & He/PIC & Ho & f \\
\hline CM112 & 54 & 2 & 0,227 & 0,000 & 1,000 \\
\hline Média & 53,666 & 2,5 & 0,334 & 0,011 & 0,965
\end{tabular}

N: Número de genótipos; A: Número de alelos; He/Pic: Heterozigosidade esperada/Conteúdo de informação polimórfica; Ho: Heterozigosidade observada; f: Coeficiente de endogamia.

O dendrograma resultante da análise SSR (Figura 3) agrupou os 58 genótipos com uma similaridade genética variando de 0,495 a 1. Observou-se o agrupamento dos genótipos em dois principais grupos ( 1 e 2) com 49,5\% de similaridade entre eles. O primeiro grupo apresentou a maioria dos genótipos, e foi subdividido em 2 subgrupos (1.1 e 1.2) com 52\% de similaridade. O segundo grupo apresentou apenas o genótipo 43. Nesse dendrograma, muitos genótipos apresentaram o mesmo padrão de banda para os 18 locos analisados, dessa forma, o número de marcadores não foi o suficiente para diferenciar os genótipos analisados. 
FACULDADE DE AGRONOMIA E MEDICINA VETERINÁRIA

Programa de Pós Graduação em Agronomia

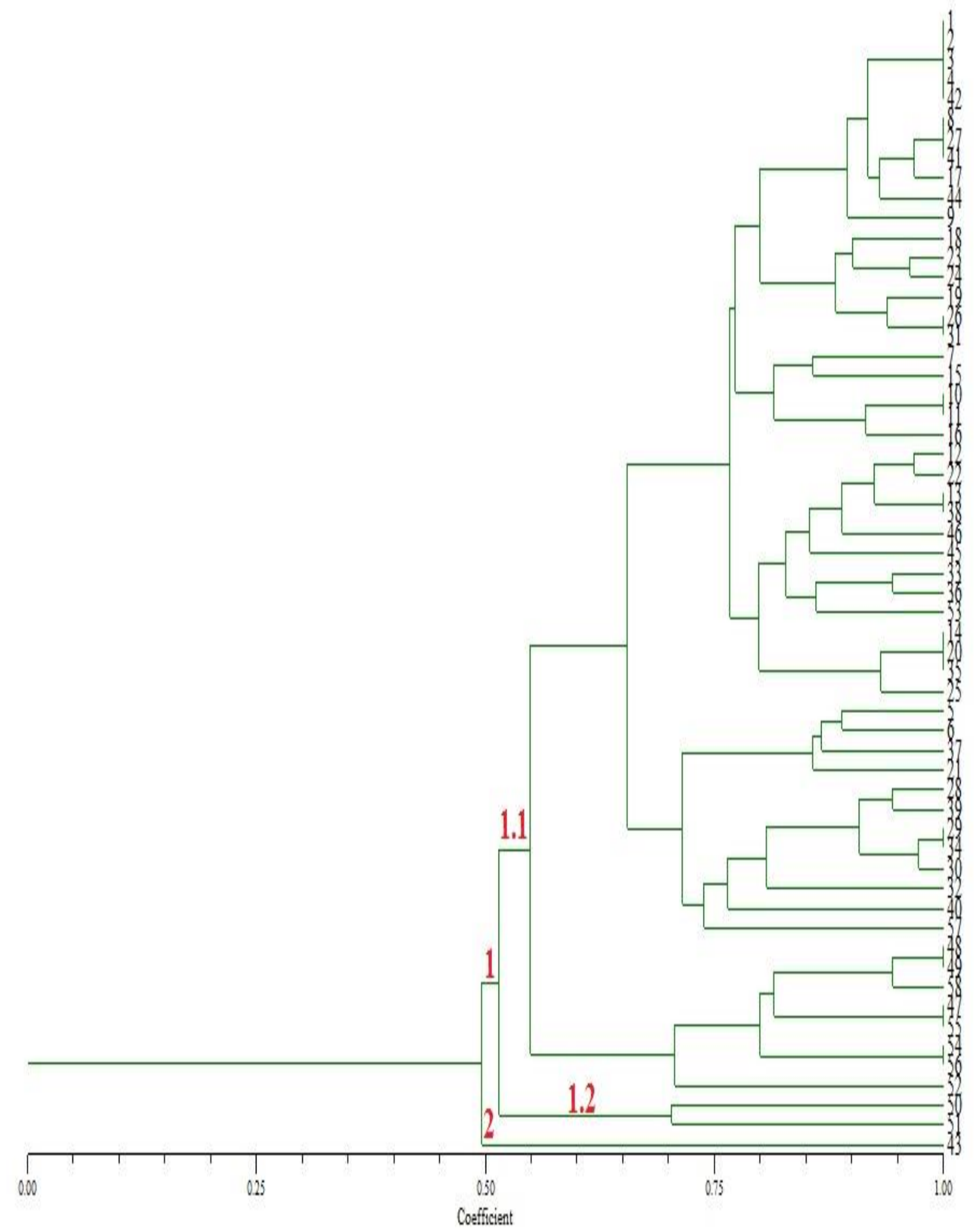

Figura 3: Dendrograma das 58 linhagens gerado a partir da análise de 18 primers SSR. 1 e 2: Grupos principais; 1.1 e 1.2: Subgrupos. 
FACULDADE DE AGRONOMIA E MEDICINA VETERINÁRIA

Programa de Pós Graduação em Agronomia

$\underline{\text { ISSR }}$

Foram pré selecionados em screnning 35 primers ISSR para os genótipos Pele de Sapo. Destes, 7 não amplificaram, 12 foram monomórficos e 16 foram polimórficos. Foram analisados apenas 13 dos 16 locos polimórficos, por apresentarem bandas bem definidas e mais nítidas (Figura 4).

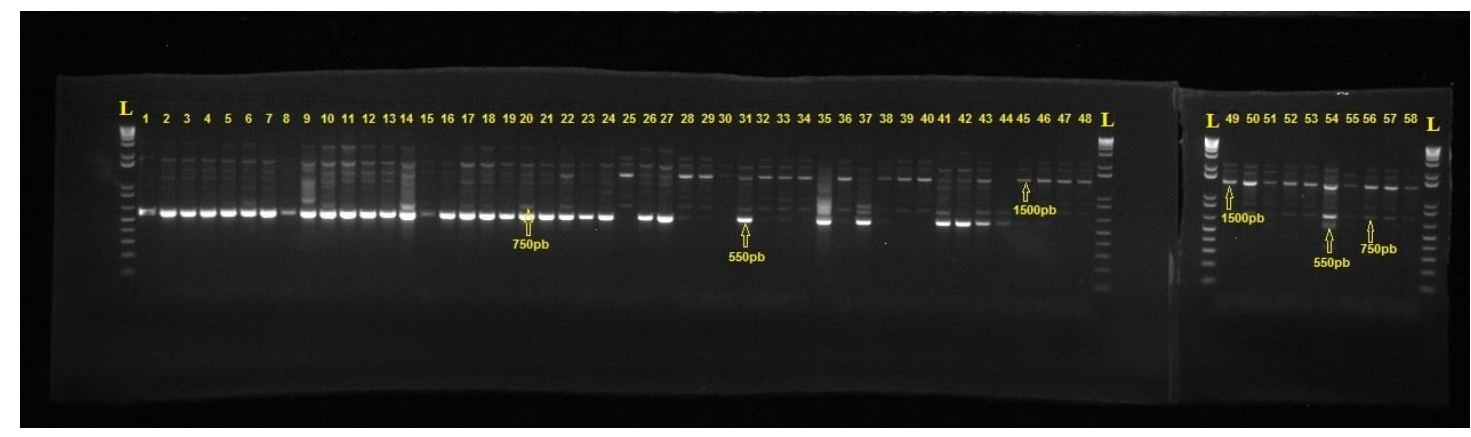

Figura 4: Primer 59Zm - Um dos 13 primers ISSR polimórficos para os 58 genótipos Pele de Sapo. L: Ladder $1 \mathrm{~kb}$ plus; As setas indicam 3 bandas polimórficas: $550,750 \mathrm{e}$ $1500 \mathrm{pb}$.

Na Tabela 5 encontram-se os primers ISSR polimórficos com suas respectivas sequências utilizados para as reações com os genótipos de melão do tipo Pele de Sapo analisados nesse estudo. A temperatura de anelamento foi de $56^{\circ} \mathrm{C}$ para todos os primers.

Tabela 5: Lista com as sequências dos primers ISSR polimórficos utilizados para as reações com os genótipos de melão do tipo Pele de Sapo analisados.

\begin{tabular}{cl}
\hline Marcador ISSR & \multicolumn{1}{c}{ Sequência } \\
\hline ISSR11zm & TGTCACACACACACACAC \\
ISSR16zm & CGGCACACACACACACAC \\
ISSR32zm & AGCAGCAGCAGC \\
ISSR39zm & AGCAGCAGCAGCAC \\
ISSR53zm & CGCAACACACACACACACACACA \\
ISSR55zm & CCTCCACACACACACACACACA \\
ISSR57zm & CGTCCACACACACACACACACA \\
ISSR58zm & CGAACCACACACACACACACACA \\
\hline
\end{tabular}


FACULDADE DE AGRONOMIA E MEDICINA VETERINÁRIA

Programa de Pós Graduação em Agronomia

\begin{tabular}{cl}
\hline Marcador ISSR & \multicolumn{1}{c}{ Sequência } \\
\hline ISSR59zm & GGCCAGCTGCTGCTGCTGCTGCT \\
ISSR60zm & GCCACGCTGCTGCTGCTGCTGCT \\
ISSR4pv & CTAGGACAGACAGACA \\
ISSR5pv & ACTGACTGACTGAGG \\
ISSR10ps & AGAGAGAGAGAGAGAGCTT \\
\hline
\end{tabular}

$\mathrm{Na}$ análise dos marcadores ISSR, foram obtidas 74 bandas polimórficas a partir dos 13 primers utilizados, número inferior ao encontrado por Goulão \& Oliveira (2001), que avaliaram a similaridade de 41 cultivares comerciais de maçã utilizando 7 primers ISSR que resultaram em 176 bandas polimórficas. Yang et al., (2005), analisaram 11 cultivares nativas de Capscicum utilizando 12 primers ISSR e obtiveram 26 bandas polimórficas.

A similaridade genética variou de 0,38 a 0,98 e o dendrograma resultante agrupou os genótipos em dois principais grupos (1 e 2) (Figura 5) com 38\% de similaridade entre eles. No primeiro grupo, foram formados dois subgrupos (1.1 e 1.2) onde a linhagem 1 foi a mais divergente, com 52\% de similaridade com as linhagens restantes dentro de seu subgrupo. No segundo grupo também foram formados dois subgrupos (2.1 e 2.2), sendo o primeiro composto apenas pela linhagem 25 que apresentou 54\% de similaridade com as outras 24 linhagens restantes dentro de seu subgrupo.

O resultado apresentado pelo uso de marcadores ISSR se apresentou mais informativo e com maior poder discriminativo, já que distinguiu todos os genótipos, ou seja, não apresentou similaridade igual a 1. Já os dados gerados em SSR apresentaram genótipos com similaridade igual a 1, e na análise de agrupamento, apenas um genótipo (43) foi alocado no segundo grupo, enquanto para marcadores ISSR, o genótipo 1 foi alocado individualmente no subgrupo 1.1 e o genótipo 25 igualmente no subgrupo 2.1, o que pode ser justificado pela presença de alelos diferentes. Dessa forma, prevê-se uma maior heterose pelo cruzamento entre linhagens dos dois principais grupos divergentes e a utilização das linhagens 43, 1 e 25 pode contribuir para aumentar a variabilidade genética no programa de melhoramento de melão. 
FACULDADE DE AGRONOMIA E MEDICINA VETERINÁRIA

Programa de Pós Graduação em Agronomia

Polido et al., (2014) avaliaram a diversidade genética entre 33 genótipos de trigo pertencentes ao BAG do IAPAR (Instituto Agronômico do Paraná) utilizando marcadores SSR e ISSR, e compararam a variabilidade genética obtida. O dendrograma resultante agrupou os genótipos em 3 e 5 grupos respectivamente. 
FACULDADE DE AGRONOMIA E MEDICINA VETERINÁRIA

Programa de Pós Graduação em Agronomia

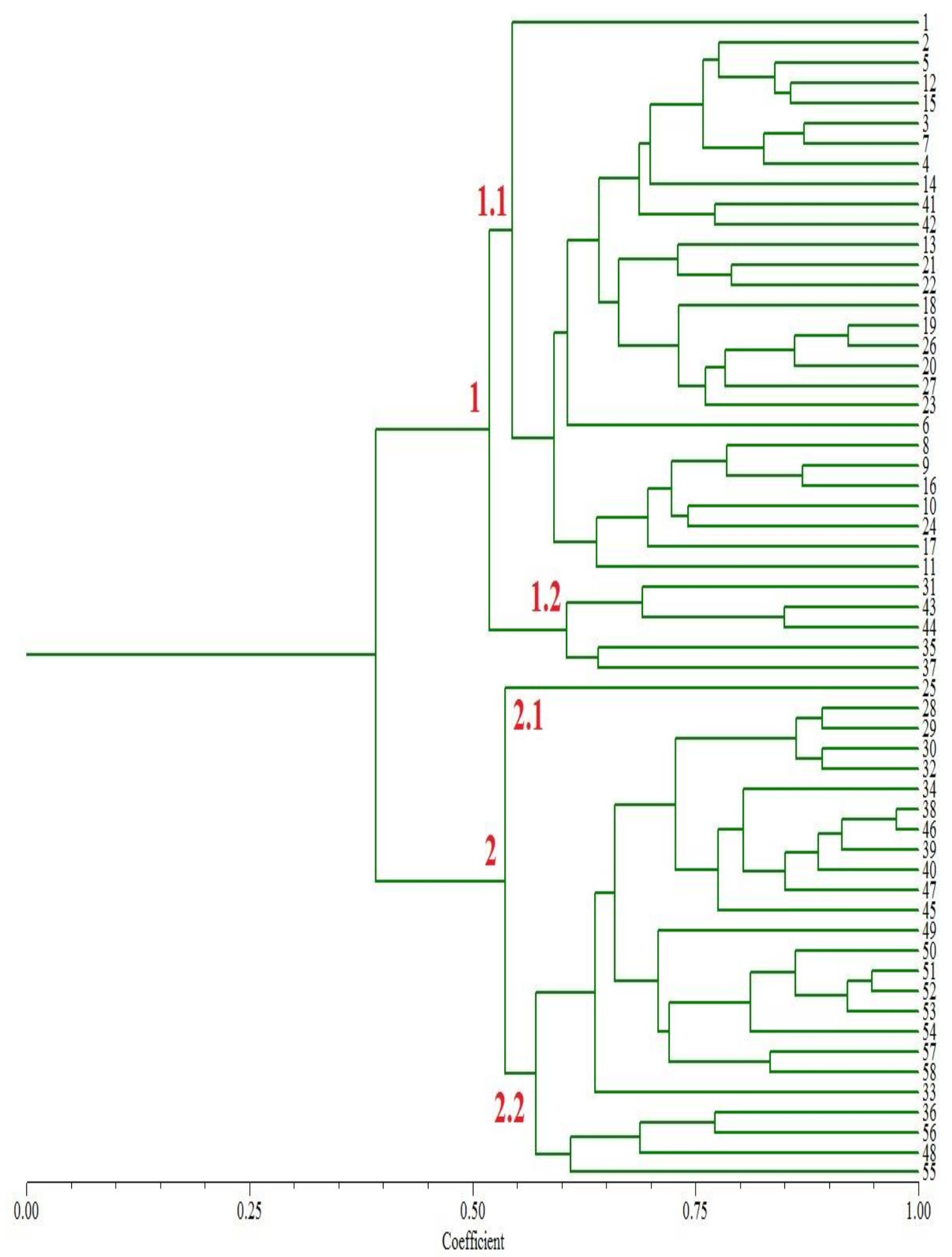

Figura 5: Dendrograma das 58 linhagens gerado a partir da análise de 74 marcadores ISSR. 1 e 2: Grupos principais; 1.1 e 1.2: Subgrupos do grupo 1; 2.1 e 2.2: Subgrupos do grupo 2. 
FACULDADE DE AGRONOMIA E MEIDICINA VETERINÁRIA

Programa de Pós Graduação em Agronomia

Os marcadores ISSR foram eficientes para a distinção de todas as linhagens e com a aplicação dos marcadores SSR pôde-se observar que o genótipo 43 apresentou um alelo exclusivo (128/128) no loco CM320, o que pode ter contribuído para que o mesmo fosse alocado individualmente no dendrograma, e portanto a utilização desse genótipo provavelmente aumentará a variabilidade alélica no programa de melhoramento.

\subsection{Genótipos do melão tipo Amarelo}

Foram pré selecionados para screnning 293 primers para os genótipos Amarelo. Destes, 108 não amplificaram, 135 foram monomórficos e 50 foram polimórficos. Foram analisados apenas 35 dos 50 locos polimórficos, por apresentarem bandas bem definidas e mais nítidas (Figura 6).

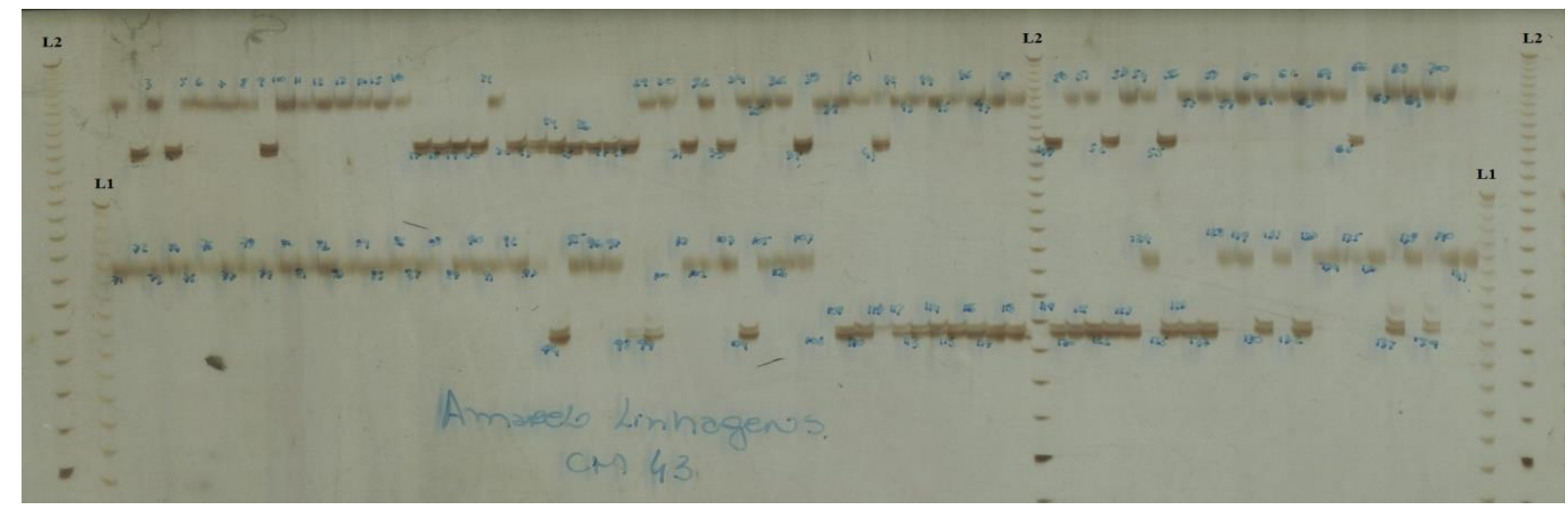

Figura 6: Primer CM43 - Um dos 35 primers SSR polimórficos para os 141 genótipos Amarelo. L1: Ladder 10pb (Genótipos 71-141). L2: Ladder 10pb (Genótipos 1-70).

Os 35 locos analisados para os 141 genótipos Amarelo amplificaram 78 alelos com média de 2,228 alelos por loco (Tabela 6), número de alelos muito superior ao descrito por Aragão (2011), que avaliou 41 acessos de melão utilizando 17 primers, também desenvolvidos por Ritschel et al., (2004), e amplificou 41 alelos.

A He/PIC variou de 0,014 nos locos CM191 e CM186 a 0,662 no loco CM303, este último apresentando-se altamente informativo (Tabela 6). De acordo com a classificação de Botstein et al., (1980), o valor médio do PIC se apresentou medianamente informativo para 
FACULDADE DE AGRONOMIA E MEDICINA VETERINÁRIA

Programa de Pós Graduação em Agronomia

os locos em questão, apresentando valor médio de 0,359. Os locos CM191 e CM186 apresentaram maior frequência do alelo principal sendo pouco informativos e os locos CM176 e CM14 o maior número de alelos (4), apesar de não apresentarem o maior valor de PIC, e junto com o loco CM303 mostraram valores altamente informativos.

A Ho apresentou muitos locos em homozigose, com valores de 0 absoluto e média de 0,010 (Tabela 6). O baixo índice de Ho observado condiz com o esperado, já que tratam-se de análises de linhagens parcialmente endogâmicas.

O coeficiente de endogamia (f) variou de 0,764 no loco CM227 a 1 em 13 dos 35 locos analisados, e o valor médio foi de 0,970 , muito próximo de 1 , indicando alta taxa de endogamia (Tabela 6).

Tabela 6: Medidas descritivas para estudos de variabilidade baseados nos marcadores SSR polimórficos em 141 genótipos de melão do tipo Amarelo estimados pelo software GDA.

\begin{tabular}{cccccc}
\hline Loco & N & A & He/PIC & Ho & F \\
\hline CM354 & 138 & 2 & 0,471 & 0,014 & 0,969 \\
CM342 & 141 & 2 & 0,448 & 0,021 & 0,952 \\
CM347 & 135 & 2 & 0,466 & 0,022 & 0,952 \\
CM331 & 141 & 2 & 0,344 & 0,000 & 1,000 \\
CM336 & 138 & 2 & 0,311 & 0,007 & 0,976 \\
CM337 & 141 & 2 & 0,463 & 0,000 & 1,000 \\
CM320 & 141 & 2 & 0,028 & 0,000 & 1,000 \\
CM321 & 138 & 2 & 0,498 & 0,000 & 1,000 \\
CM330 & 137 & 2 & 0,501 & 0,021 & 0,956 \\
CM307 & 141 & 2 & 0,499 & 0,014 & 0,971 \\
CM306 & 140 & 2 & 0,042 & 0,000 & 1,000 \\
CM303 & 137 & 3 & 0,662 & 0,000 & 1,000 \\
CM302 & 139 & 2 & 0,449 & 0,014 & 0,968 \\
CM253 & 140 & 2 & 0,393 & 0,007 & 0,981 \\
CM254 & 140 & 3 & 0,355 & 0,028 & 0,919
\end{tabular}


FACULDADE DE AGRONOMIA E MEIDICINA VETERINÁRIA

Programa de Pós Graduação em Agronomia

\begin{tabular}{cccccc} 
Loco & N & A & He/PIC & Ho & F \\
\hline CM248 & 140 & 2 & 0,449 & 0,035 & 0,920 \\
CM227 & 140 & 2 & 0,120 & 0,028 & 0,764 \\
CM244 & 140 & 3 & 0,462 & 0,028 & 0,938 \\
CM230 & 139 & 2 & 0,479 & 0,000 & 1,000 \\
CM191 & 138 & 2 & 0,014 & 0,000 & 1,000 \\
CM186 & 138 & 2 & 0,014 & 0,000 & 1,000 \\
CM176 & 140 & 4 & 0,515 & 0,035 & 0,930 \\
M161 & 140 & 2 & 0,337 & 0,014 & 0,957 \\
CM185 & 139 & 2 & 0,176 & 0,007 & 0,959 \\
CM125 & 140 & 2 & 0,477 & 0,007 & 0,985 \\
CM105 & 139 & 2 & 0,455 & 0,007 & 0,984 \\
CM140 & 139 & 2 & 0,082 & 0,000 & 1,000 \\
CM83 & 137 & 2 & 0,405 & 0,007 & 0,982 \\
CM95 & 140 & 2 & 0,412 & 0,007 & 0,982 \\
CM51 & 140 & 2 & 0,126 & 0,007 & 0,943 \\
CM43 & 140 & 2 & 0,449 & 0,007 & 0,984 \\
CM40 & 140 & 2 & 0,133 & 0,000 & 1,000 \\
CM33 & 140 & 3 & 0,511 & 0,000 & 1,000 \\
CM14 & 141 & 4 & 0,528 & 0,021 & 0,959 \\
CM02 & 140 & 2 & 0,475 & 0,000 & 1,000 \\
\hline Média & 139,342 & 2,228 & 0,359 & 0,010 & 0,970 \\
\hline N 95000
\end{tabular}

N: Número de genótipos; A: Número de alelos; He/Pic: Heterozigosidade esperada/Conteúdo de informação polimórfica; Ho: Heterozigosidade observada; f: Coeficiente de endogamia.

O dendrograma resultante da análise SSR (Figura 7) agrupou os 141 genótipos com uma similaridade genética variando de 0,52 a 1. Observou-se o agrupamento dos genótipos em dois principais grupos ( 1 e 2) com $52 \%$ de similaridade entre eles. O primeiro grupo apresentou a maioria dos genótipos, e foi subdividido em 2 subgrupos (1.1 e 1.2) com $57 \%$ de similaridade. O segundo grupo apresentou os genótipos 5 e 124 individualizados em um subgrupo (2.2) com 67\% de similaridade com os genótipos restantes dentro deste grupo. 
FACULDADE DE AGRONOMIA E MEIDICINA VETERINÁRIA

Programa de Pós Graduação em Agronomia

Portanto, prevê-se uma maior heterose pelo cruzamento entre linhagens dos dois principais grupos divergentes, e a utilização dos genótipos 5 e 124 em futuros cruzamentos para obtenção de híbridos. 
FACULDADE DE AGRONOMIA E MEIDICINA VETERINÁRIA

Programa de Pós Graduação em Agronomia

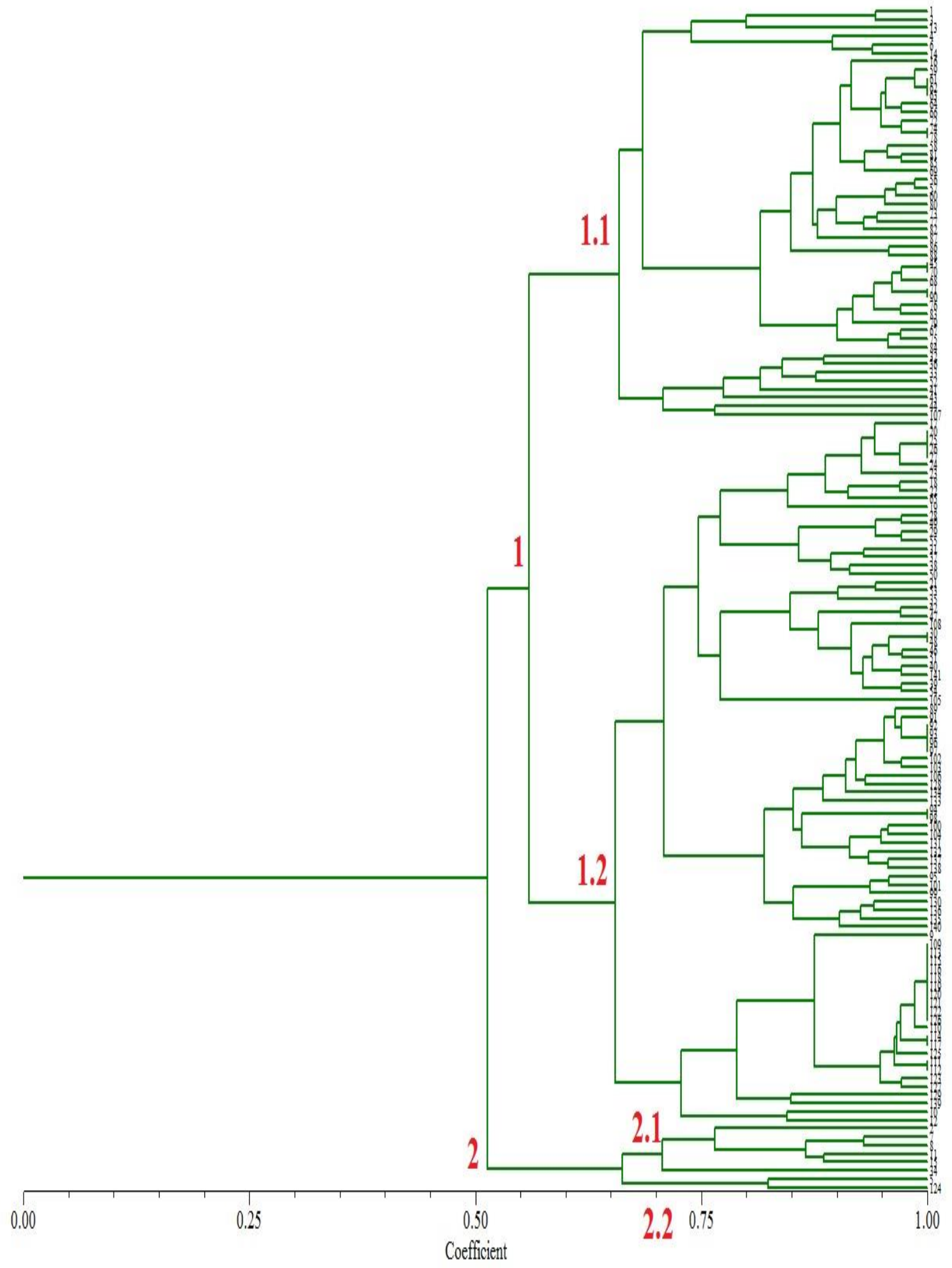

Figura 7: Dendrograma das 141 linhagens gerado a partir da análise de 35 primers SSR. 1 e 2: Grupos principais; 1.1 e 1.2: Subgrupos do grupo 1; 2.1 e 2.2: Subgrupos do grupo 2. 
FACULDADE DE AGRONOMIA E MEDICINA VETERINÁRIA

Programa de Pós Graduação em Agronomia

3.3 Genótipos de melão tipo Cantaloupe

Foram pré selecionados para screnning 297 primers para os genótipos Cantaloupe. Destes, 108 não amplificaram, 121 foram monomórficos e 68 foram polimórficos. Foram analisados 47 dos 68 locos polimórficos, por apresentarem bandas bem definidas e mais nítidas (Figura 8).

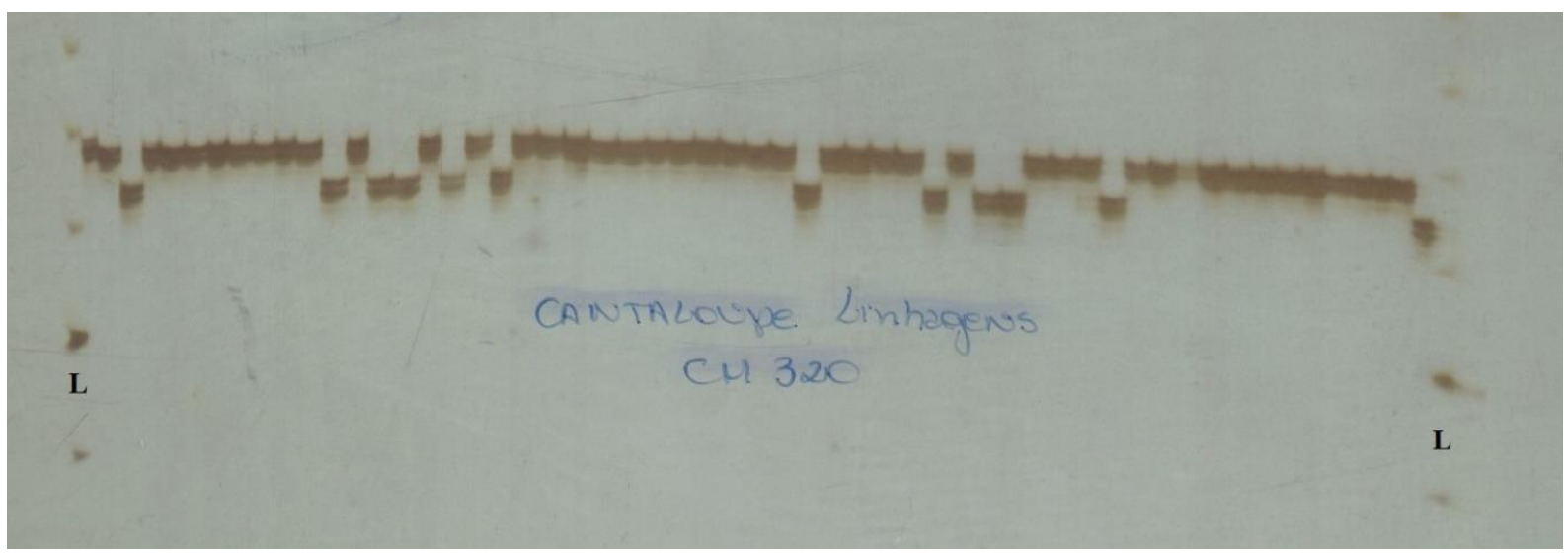

Figura 8: Primer CM320 - Um dos 47 primers SSR polimórficos para os 56 genótipos Cantaloupe. L: Primeira e última coluna: Marcador de peso molecular Ladder 10pb.

Os 47 locos analisados para os 56 genótipos Cantaloupe amplificaram 103 alelos com média de 2,191 alelos por loco (Tabela 7), número de alelos muito superior ao descrito por Aragão (2011), que avaliou 41 acessos de melão utilizando 17 primers, também desenvolvidos por Ritschel et al., (2004), e amplificou 41 alelos. Contudo, o número de alelos foi inferior ao constatado por Kaçar et al., (2012), que analisaram a diversidade genética de 81 genótipos de melão da Turquia em comparação com 15 genótipos referência obtidos na França. Nesse estudo 123 alelos foram amplificados a partir de 20 primers SSR, que geraram uma média de 6,15 alelos por loco.

A He/PIC variou de 0,069 nos locos CM331 e CM34 a 0,504 no loco M161, este último apresentando-se muito informativo (Tabela 7). De acordo com a classificação de Botstein et al., (1980), o valor médio do PIC, de 0,294, se apresentou medianamente informativo para os locos em questão. 
FACULDADE DE AGRONOMIA E MEDICINA VETERINÁRIA

Programa de Pós Graduação em Agronomia

A Ho apresentou muitos locos em homozigose, com 37 locos apresentando valor valores de zero absoluto e média de 0,009 (Tabela 7). O baixo índice de Ho observado condiz com o esperado, já que tratam-se de análises de linhagens parcialmente endogâmicas, e dentre os 3 tipos de linhagens analisadas neste trabalho, foi a que apresentou mais locos em homozigose.

O coeficiente de endogamia (f) variou de 0,488 no loco CM331 a 1 em 31 dos 47 locos analisados, e o valor médio foi de 0,967 , muito próximo de 1 , indicando alta taxa de endogamia (Tabela 7).

Tabela 7: Medidas descritivas para estudos de variabilidade baseados nos marcadores SSR polimórficos em 56 genótipos de melão do tipo Cantaloupe estimados pelo software GDA.

\begin{tabular}{cccccc}
\hline Loco & N & A & He/PIC & Ho & f \\
\hline CM320 & 56 & 2 & 0,339 & 0,000 & 1,000 \\
CM347 & 56 & 2 & 0,359 & 0,107 & 0,704 \\
CM336 & 56 & 2 & 0,118 & 0,017 & 0,850 \\
CM317 & 56 & 3 & 0,103 & 0,000 & 1,000 \\
CM312 & 56 & 2 & 0,359 & 0,000 & 1,000 \\
CM319 & 56 & 2 & 0,102 & 0,000 & 1,000 \\
CM324 & 56 & 2 & 0,426 & 0,000 & 1,000 \\
CM331 & 56 & 2 & 0,069 & 0,357 & 0,488 \\
CM311 & 55 & 2 & 0,476 & 0,000 & 1,000 \\
CM326 & 56 & 3 & 0,465 & 0,000 & 1,000 \\
CM303 & 56 & 2 & 0,329 & 0,017 & 0,946 \\
CM305 & 56 & 2 & 0,378 & 0,000 & 1,000 \\
CM253 & 56 & 2 & 0,149 & 0,017 & 0,881 \\
CM254 & 55 & 2 & 0,450 & 0,018 & 0,960 \\
Loco & $\mathrm{N}$ & A & He/PIC & Ho & $\mathrm{f}$ \\
CM225 & 54 & 2 & 0,470 & 0,000 & 1,000 \\
CM227 & 56 & 2 & 0,488 & 0,071 & 0,854 \\
& & & & &
\end{tabular}


FACULDADE DE AGRONOMIA E MEDICINA VETERINÁRIA

Programa de Pós Graduação em Agronomia

\begin{tabular}{|c|c|c|c|c|c|}
\hline Loco & $\mathbf{N}$ & $\mathbf{A}$ & He/PIC & Ho & $\mathbf{f}$ \\
\hline CM247 & 56 & 2 & 0,481 & 0,000 & 1,000 \\
\hline CM248 & 55 & 2 & 0,382 & 0,000 & 1,000 \\
\hline CM228 & 56 & 3 & 0,408 & 0,017 & 0,956 \\
\hline CM230 & 56 & 2 & 0,207 & 0,017 & 0,914 \\
\hline CM190 & 55 & 2 & 0,300 & 0,000 & 1,000 \\
\hline CM197 & 56 & 2 & 0,500 & 0,017 & 0,964 \\
\hline CM186 & 56 & 2 & 0,329 & 0,017 & 0,946 \\
\hline CM191 & 55 & 3 & 0,260 & 0,000 & 1,000 \\
\hline CM224 & 56 & 3 & 0,483 & 0,000 & 1,000 \\
\hline CM218 & 56 & 2 & 0,503 & 0,000 & 1,000 \\
\hline M171 & 55 & 2 & 0,450 & 0,018 & 0,960 \\
\hline CM173 & 56 & 2 & 0,102 & 0,000 & 1,000 \\
\hline CM123 & 56 & 2 & 0,272 & 0,000 & 1,000 \\
\hline M168 & 56 & 2 & 0,496 & 0,017 & 0,964 \\
\hline CM174 & 55 & 2 & 0,237 & 0,018 & 0,924 \\
\hline CM176 & 53 & 3 & 0,091 & 0,018 & 0,795 \\
\hline CM165 & 56 & 2 & 0,207 & 0,017 & 0,914 \\
\hline CM64 & 56 & 3 & 0,135 & 0,000 & 1,000 \\
\hline CM106 & 55 & 2 & 0,300 & 0,000 & 1,000 \\
\hline M161 & 56 & 2 & 0,504 & 0,000 & 1,000 \\
\hline CM93 & 56 & 2 & 0,164 & 0,000 & 1,000 \\
\hline CM90 & 55 & 2 & 0,300 & 0,000 & 1,000 \\
\hline CM87 & 56 & 2 & 0,501 & 0,000 & 1,000 \\
\hline CM140 & 54 & 3 & 0,072 & 0,000 & 1,000 \\
\hline CM43 & 56 & 2 & 0,296 & 0,000 & 1,000 \\
\hline CM25 & 56 & 2 & 0,133 & 0,000 & 1,000 \\
\hline CM27 & 56 & 2 & 0,133 & 0,000 & 1,000 \\
\hline CM12 & 56 & 3 & 0,135 & 0,000 & 1,000 \\
\hline CM01 & 55 & 2 & 0,070 & 0,000 & 1,000 \\
\hline CM21 & 55 & 2 & 0,224 & 0,000 & 1,000 \\
\hline
\end{tabular}


FACULDADE DE AGRONOMIA E MEDICINA VETERINÁRIA

Programa de Pós Graduação em Agronomia

\begin{tabular}{cccccc} 
Loco & N & A & He/PIC & Ho & f \\
\hline CM34 & 56 & 2 & 0,069 & 0,000 & 1,000 \\
\hline Média & 55,61 & 2,19 & 0,294 & 0,009 & 0,967
\end{tabular}

N: Número de genótipos; A: Número de alelos; He/Pic: Heterozigosidade esperada/Conteúdo de informação polimórfica; Ho: Heterozigosidade observada; f: Coeficiente de endogamia.

O dendrograma resultante da análise SSR (Figura 9) agrupou os 56 genótipos com uma similaridade genética variando de 0,49 a 1. Observou-se o agrupamento dos genótipos em dois principais grupos ( 1 e 2 ) com $49 \%$ de similaridade entre eles. O primeiro grupo apresentou a maioria dos genótipos, e foi subdividido em 2 subgrupos (1.1 e 1.2) com 64\% de similaridade. O segundo grupo apresentou o genótipo 18 individualizado em um subgrupo (2.2) com 58\% de similaridade com os genótipos restantes dentro deste grupo. A individualização do genótipo 18 no subgrupo 2.2 pode ser justificado pela presença dos alelos exclusivos 160/160 nos locos CM64 e CM140. Portanto, prevê-se uma maior heterose pelo cruzamento entre linhagens dos dois principais grupos divergentes e a utilização do genótipo 18 provavelmente aumentará a variabilidade alélica para o programa de melhoramento da Embrapa Hortaliças. 
FACULDADE DE AGRONOMIA E MEDICINA VETERINÁRIA

Programa de Pós Graduação em Agronomia

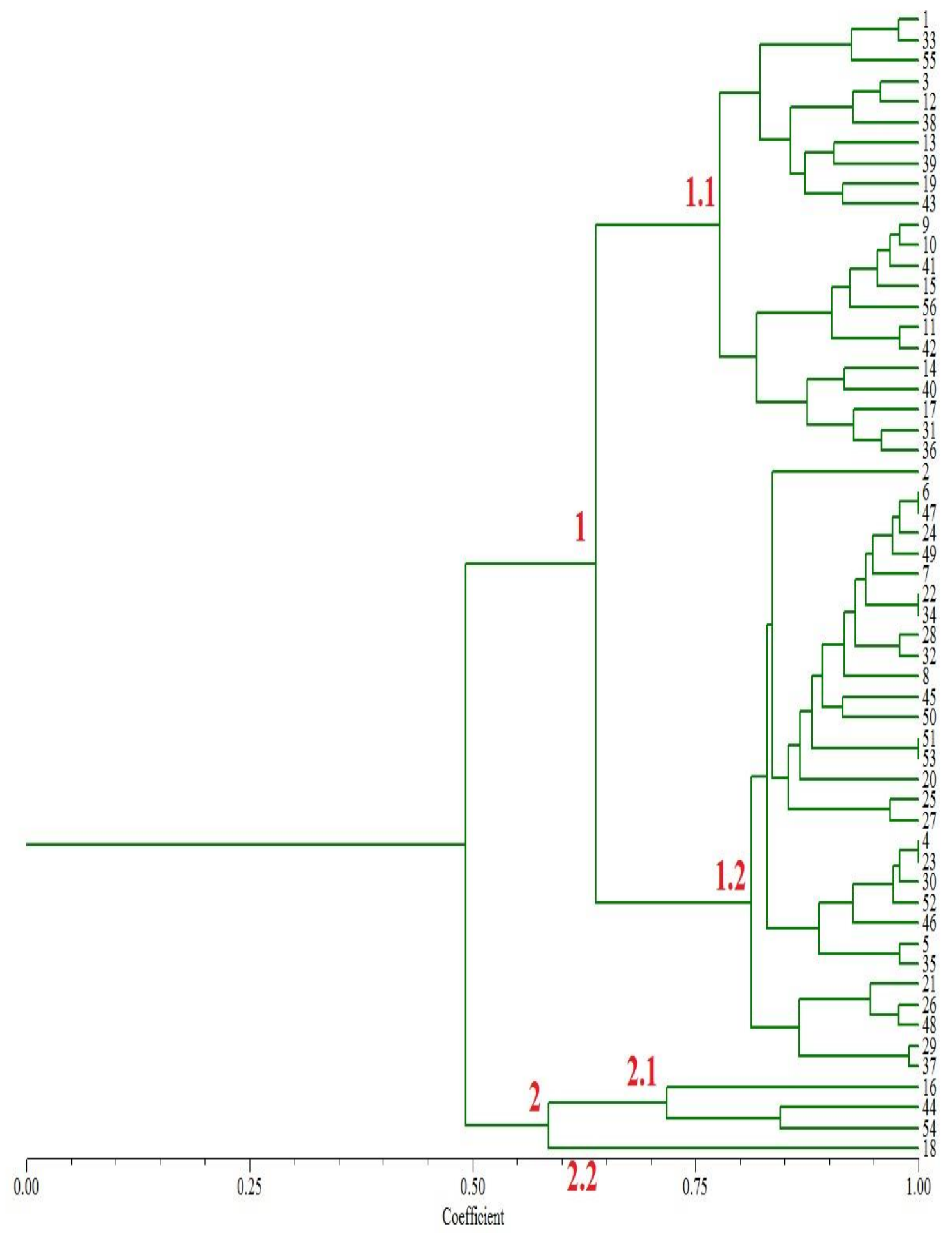

Figura 9: Dendrograma das 56 linhagens gerado a partir da análise de 47 primers SSR. 1 e 2: Grupos principais; 1.1 e 1.2: Subgrupos do grupo 1; 2.1 e 2.2: Subgrupos do grupo 2. 
FACULDADE DE AGRONOMIA E MEIDICINA VETERINÁRIA

Programa de Pós Graduação em Agronomia

\section{CONSIDERAÇÕES FINAIS}

A variabilidade genética é fator essencial para produção de híbridos superiores e cultivares com maior heterose. Na análise da variabilidade das linhagens de melão, os melões do tipo Amarelo apresentaram-se mais variáveis com valor médio de PIC/He superior $(0,359)$, seguido do tipo Pele de Sapo $(0,334)$ e Cantaloupe $(0,294)$.

Os primers CM191, CM320 e CM331 apresentaram-se polimórficos para os três tipos de linhagens analisadas, portanto os mesmos podem ser utilizados em estudos posteriores com linhagens desses três tipos de melão. Os primers CM43, CM140, CM161, CM176, CM186, CM191, CM227, CM230, CM248, CM253, CM254, CM303, CM320, CM331, CM336 e CM347, apresentaram-se polimórficos apenas para os tipos Amarelo e Cantaloupe e, portanto podem ser indicados para estudos com esses dois tipos de linhagens de melão.

Sugere-se, também, pela análise de variabilidade dos três tipos de melão, mais ciclos de autofecundação para os genótipos que apresentaram mesmo padrão de banda (similaridade genética igual a 1). Dessa forma, provavelmente possíveis alelos exclusivos podem ainda ser fixados. 


\section{REFERÊNCIAS BIBLIOGRÁFICAS}

ACAMPORA, A.; CIAFFI, M.; PACE, C.; PAOLACCI, A.R. et al., (2007). Pattern of variation for seed size traits and molecular markers in Italian germplasm of Phaseolus coccineus L. Euphytica, v. 157, p. 69-82.

ARAGÃO de, F.A.S. Divergência genética de acessos e interação genótipo $\mathbf{x}$ ambiente de famílias de meloeiro. 2011. 137 f. Tese (Doutorado em Agronomia: Melhoramento Genético Vegetal). Universidade Federal Rural do Semi-Árido, Mossoró, 2011.

BOTSTEIN, D.; WHITE, R.L.; SKOLNICK, M.H.; DAVIES, R.W. Construction of a genetic linkage map in man using restriction fragment length polymorphisms. American Journal of Human Genetics, v.32, p 314-331, 1980.

FALEIRO, F.G. Marcadores Genético-moleculares - Aplicados a programas de conservação e uso de recursos genéticos. Planaltina - DF: Embrapa Cerrados, 2007. 99 p.

FERREIRA, M.E.; GRATTAPAGLIA, D. Introdução ao uso de marcadores moleculares em análise genética. Brasília: EMPRAPA-CENARGEN, 3ed. 1998. 220 p.

FREITAS de, L.B; BERED, F. Genética e Evolução Vegetal. In: CAVALLI, S.S. (Ed.). Polimorfismos Moleculares. Porto Alegre: UFRS, 2003. p. 311-332.

GIANFILIPPI, F.ianfilippi F (2006). Studio Della Diversita Molecolare in Popolazioni Locali Italiane di Lenticchia (Lens culinaris Medik) Tramite Marcatori ISSR. Tesi de Láurea Agrária. Università degli studi della Tuscia, Tuscia.

KAÇAR, Y.A.; SIMSEK, O.; SOLMAZ, I.; SARI, N.; MENDI, Y.Y. Genetic diversity among melon accessions (Cucumis melo) from Turkey based on SSR markers. Genetics and Molecular Research. 29Novembro 2012. Disponívels em http://www.geneticsmr.com//year2012/vol114/pdf/gmr2144.pdf Acesso em 02 fevereiro 2016.

LEWIS, P.O.; ZAYKIN, D. (2001).GDA - pc Genetic Data Analysis, Version 1.1.

LOPÉZ-SESÉ, A.I.; SATUB, J.E.; KATZIR, N.; GÓMEZ-GUILLAMÓN, M.L. 2002.Estimation of between and whithin accession variaton in selected Spanish melon germplasm using RAPD and SSR markers to assess strategies for large collection evaluation. Euphytica 127: 41-51.

LYNCH, M. The Similarity Index and DNA Fingerprinting.Mol Biol Evol, 1990.

NEI, M. Molecular evolutionary genetics, New York: Columbia University, 1987, 284 p.

OHSE, B.J.G. Desenvolvimento de marcadores microssatélites (SSRs) para análise genética de melão (Cucumis melo L;). 2005. 33 F. Trabalho de Conclusão de Curso (Graduação em Biologia). Centro Universitário de Brasília, Brasília, 2005.

POLIDO, P.B.; RAMPIM, M.C.; PIFFER, R.D.; LUIZ, G.C.; GARBÚBLIO, D.D.; SOUDAde, S.G.H. Avaliação da diversidade genética em germoplasma de trigo (Trticum aestivum) utilizando 
FACULDADE DE AGRONOMIA E MEIDICINA VETERINÁRIA

Programa de Pós Graduação em Agronomia

marcadores ISSR e SSR. In: CONGRESSO BRASILEIRO DE RECURSOS GENÉTICOS, 3. 2014, Santos. Resumos do...Santos: CBRG, 2014.

RITSCHEL, P.S.; LINS, T.D.de L.; TRISTAN, R.L; BUSO, G.S.C.; BUSO, J.A.; FERREIRA, M.E. Development of microsatellite markers from an enriched genomic library for genetic analysis of melon (Cucumis melo L.). BMC Plant Biology, v.4, n.1, p.9-24, 2004.

ROBINSON, I. P. Aloenzimas na genética de populações de plantas. In: ALFENAS, A. C. (Ed.) Eletroforese de isoenzimas e proteínas afins; fundamentos e aplicações em plantas e microrganismos. cap. 7, p.329-380 Viçosa: UFV, 1998.

ROHLF, J.F. NTSYS-pc Numerical Taxonomy and Multivariate Analysis System, Version 2.2. New York, Exeter Publications. 1992.

SENIOR, M. L.; MURPHY, J. P.; GOODMAN, M. M.; STUBER, C. W. Utility of SSR for determining genetic similarities and relationships in maize using na agarose gel system. Crop Science, v. 38, p. 1088-1098, 1998.

SZABÓ, Z.; GYULAI, G.; HUMPHREYS, M.; HORVÁTH, L.;BITTSÁNSZKY, A.; LÁGLER, R.; HESZKY. L. Genetic variation of melon (C. melo) compared to an extinct landrace from the Middle Ages (Hungary) I. rDNA, SSR and SNP analysis of 47 cultivars. Euphytica, v.146, p.87-94, 2005.

TZURI, G.; PORTNOY, V.; DAUBE-MOZES, N.; KATZIR, N. Genetic diversity of melon (Cucumis melo L.) estimated by SSR markers. Cucurbit Genetics Cooperative Report, 28-29: 14-16. 2006.

YANG, R.; KONG, J.; WU, X.; DENG, Z.; CHEN, Q.W.Application of ISSR Markers in Genetic Polymorphism of Capsicum frutescens L. Journal os Sganghai University (Natural Science Edition). Shanghai, 2005. Disponível em: http://en.cnki.com.cn/Article_en/CJFDTOTALSDXZ200504020.htm Acesso em 08 fevereiro 2016. 
FACULDADE DE AGRONOMIA E MEDICINA VETERINÁRIA

Programa de Pós Graduação em Agronomia

\title{
CAPÍTULO 2
}

\section{Análise da variabilidade genética de cultivares comerciais de melão utilizando marcadores moleculares SSR.}

\begin{abstract}
RESUMO
\end{abstract}
Este estudo avaliou a variabilidade genética de 88 acessos de melão compostos de 73 cultivares comerciais pertencentes aos grupos Inodorus e Cantaloupesis, e de 15 introduções (PIs), provenientes do Programa de melhoramento de melão da Embrapa Hortaliças. Foram coletadas folhas de plântulas e foi realizada extração do DNA genômico e posterior quantificação do mesmo. Foram utilizados marcadores SSR para avaliação de todos os genótipos que foram amplificados por meio de reações de PCR e os fragmentos visualizados por meio de eletroforese em gel de poliacrilamida 5\%. Foram selecionados 44 primers SSR que amplificaram um total de 204 alelos. A Heterozigosidade esperada variou de 0,226 no loco CM305 a 0,828 no loco CM89 com média de 0,520. O PIC apresentou índice médio de 0,459 sendo medianamente informativo. O índice de Heterozigosidade observada variou de 0,055 no loco CM244, sendo o loco com maior proporção de homozigotos, a 0,451 no loco CM08. O dendrograma gerado para as 73 cultivares agrupou os genótipos em 2 principais grupos, não havendo associação com a classificação dos genótipos no agrupamento. Contudo, o número de marcadores SSR foi o suficiente para predizer ampla variabilidade genética entre as cultivares estudadas, com similaridade entre 0,35 a 0,97 . Foi identificado um conjunto de 17 primers que foram úteis na distinção das 73 cultivares com índice de 99,99\% de exclusão de parentais. Esses primers podem ser utilizados em pesquisas posteriores com as cultivares analisadas nesse estudo, bem como, em situações de proteção de cultivares, sendo importante ferramenta na distinção efetiva e rápida dos genótipos, podendo também ser utilizados em situações de disputas comerciais referentes à certificação ou não das principais cultivares de melão usadas no país. O dendrograma apresentado para as 73 cultivares e os 15 genótipos PIs não apresentou associação com a classificação dos genótipos no agrupamento e os 15 PIs apresentaram-se bem dispersos com índices de similaridade que se assemelham aos dois grupos estudados (Inodorus e Cantaloupensis). 
FACULDADE DE AGRONOMIA E MEIDICINA VETERINÁRIA

Programa de Pós Graduação em Agronomia

Palavras-Chave: Cucumis melo L., Variabilidade genética, Cultivares, PI, Microssatélites.

\begin{abstract}
This study evaluated the genetic variability of 88 melon accessions composed of 73 commercial cultivars belonging to Inodorus and Cantaloupesis groups, and 15 introductions (PIs) from Embrapa Hortaliças melon breeding program. Leaves of seedlings were collected and genomic DNA extraction and subsequently quantification was performed. SSR markers were used for evaluation of all genotypes and were amplified by means of PCR reactions and the resulting fragments were visualized by electrophoresis in gel polyacrylamide 5\%. 44 SSR markers were selected and amplified a total of 204 alleles. The expected heterozygosity ranged from 0.226 in loco CM305 to 0.828 in loco CM89 with an average of 0.520 . The PIC had an average rate of 0.459 being mildly informative. The observed heterozygosity index ranged from 0.055 in loco CM244, being the loco with the highest proportion of homozygotes, to 0.451 in loco CM08. The dendrogram generated for the 73 cultivars grouped genotypes in two main groups, there was no association with the type classification of the genotypes in the group. However, the number of SSR markers was enough to predict high genetic variability among cultivars, since none of them showed genetic similarity equal to 1 . A set of 17 primers were useful in distinguishing the 73 cultivars and has been identified with an index 99\% parental exclusion. These primers can be used in further research with the cultivars analyzed in this study as well, can help to protect them and it is important tool for effective and fast distinction of genotypes. The results were satisfactory allowing to predict a wide genetic base among genotypes representing major source of genetic variability for the national cultivars germplasm. The dendrogram presented with the 73 cultivars and the 15 PI genotypes did not show association with the classification by type. The 15 PIs were well dispersed with similarities that resemble the two groups (Inodorus and Cantaloupensis).
\end{abstract}

Keywords: Cucumis melo L., genetic variability, cultivars, PI, SSR. 
FACULDADE DE AGRONOMIA E MEDICINA VETERINÁRIA

Programa de Pós Graduação em Agronomia

\section{INTRODUÇÃO}

A espécie Cucumis melo L. apresenta uma grande diversidade fenotípica nas suas variedades, o que não significa necessariamente, uma grande variabilidade genética. Os melões mais cultivados no Brasil pertencem ao grupo Inodorus tipo amarelo, entretanto há uma tendência ao aumento da demanda por melões do grupo Cantaloupensis, sobretudo para exportação. Como a preferência do mercado nacional é concentrada nos frutos do tipo amarelo, há a possibilidade de que a base genética das cultivares comerciais esteja relativamente estreita, devido à perda de genes importantes no melhoramento, havendo a necessidade de se introduzir genes externos para maiores possibilidades de recombinações que gerem fontes de resistência às principais doenças e genótipos superiores (heterose), contribuindo significativamente no auxílio do melhoramento do melão, além da contribuição intelectual e científica para a agricultura.

Análises moleculares que utilizam técnicas da biotecnologia moderna, sobretudo de marcadores moleculares, contribuem significativamente para esses estudos, que geram informações potencialmente importantes para a ampliação da base genética dos programas de melhoramento (SHIRAN et al., 2007).

Alguns autores assumem haver uma erosão genética na espécie C.melo L. (QUEIROZ, 2004; GARCIA et al., 1998), e de fato, o melhoramento do melão no Brasil tem base no melão do tipo Amarelo, o que pode ter contribuído para a perda de genes importantes, presentes em espécies silvestres ou variedades plantadas por pequenos agricultores. Dessa forma, estudos de caracterização e análise da variabilidade genética de cultivares comerciais permitem a avaliação da base genética da cultura para possíveis introduções de genes de interesse.

Outra aplicação promissora do uso dos marcadores moleculares é no auxílio da proteção de cultivares e na resolução de disputas comerciais. Para algumas espécies, como 
FACULDADE DE AGRONOMIA E MEIDICINA VETERINÁRIA

Programa de Pós Graduação em Agronomia

melancia e uva, já existem alguns estudos, mas com a espécie C.melo L. ainda não são observados relatos.

Com a espécie Citrullus lanatus (Thunb.) foram realizados diversos trabalhos com marcadores moleculares SSR (JARRET et al., 1996; GUERRA-SANZ, 2002, KNOW et al., 2010) com objetivo de verificar a variabilidade entre as variedades existentes.

Diante do exposto, este trabalho teve como objetivos: Avaliar a base genética de cultivares comerciais de melão por meio do estudo da variabilidade genética de genótipos pertencentes aos grupos Inodorus e Cantaloupensis; com base no padrão alélico e estimativas de variabilidade, gerar dados de referência e suporte para proteção de cultivares, guiar programas de melhoramento e manejo de recursos genéticos.

\section{MATERIAL E MÉTODOS}

\subsection{Material vegetal}

O material obtido para o estudo foi proveniente do banco de germoplasma do programa de melhoramento de melão da Embrapa Hortaliças (Centro Nacional de Pesquisa de Hortaliças - CNPH), e consistiu de 73 acessos compostos de cultivares comerciais, 44 pertencentes ao grupo Inodorus e 29 pertencentes ao grupo Cantaloupensis, e 15 introduções (Plant Introduction - PI) (Tabelas 8 e 9), coletados em casa de vegetação na fase de plântula. O estudo foi desenvolvido nas dependências do Laboratório de Genética Vegetal - LGV, da Embrapa Recursos Genéticos e Biotecnologia. Foram utilizados marcadores SSR para avaliação de todos os genótipos.

Tabela 8: Lista de melões Inodorus e PIs utilizados nesse estudo. Número: Número atribuído ao acesso; Cultivar: Nome da cultivar; Tipo: Tipo varietal.

\begin{tabular}{ccc}
\hline Número & Cultivar & Tipo \\
\hline 01 & CNPH 05-1003 (Amarillo Oro) & Amarelo \\
02 & Jangada (F2) & Amarelo \\
03 & CNPH 06-1033 (Piel Del Sapo) & Pele de Sapo
\end{tabular}


FACULDADE DE AGRONOMIA E MEDICINA VETERINÁRIA

Programa de Pós Graduação em Agronomia

04

05

Número
CNPH 87-338 (Eldorado 300)

CNPH 82-015 (Valenciano Amarelo)

Cultivar

$\begin{array}{cc}06 & \text { CNPH 04-995 (RML5006) } \\ 07 & \text { CNPH 00-888 (Gold Pride) } \\ 08 & \text { Royal Sweet } \\ 09 & \text { Potiguar } \\ 10 & \text { Doren }\end{array}$

$$
\text { CNPH 05-1011 (RML0031) }
$$$$
\text { Melody }
$$$$
\text { Goldex }
$$

Diplomata

Gold Mine

Natal

Iracema

Mandacaru

Soleares

Best Bite

CNPH 05-1028 (Frevo)

AF4945

Durasol

CNPH 05-1026 (Rochedo)

CNPH 00-887 (Yellow Queen)

CNPH 00-886 (Yellow King)

CNPH 00-881 (AF646)

CNPH 00-880 (AF682)

CNPH 05-1021 (Vereda)

Hibrix

CNPH 05-1022 (10/00)

$10 / 00$

CNPH 05-1029 (Orange Flesh)
Amarelo

Amarelo

\section{Tipo}

Amarelo

Amarelo

Honey Dew

Amarelo

Amarelo

Amarelo

Amarelo

Amarelo

Amarelo

Amarelo

Amarelo

Amarelo

Amarelo

Amarelo

Amarelo

Amarelo

Amarelo

Amarelo

Amarelo

Amarelo

Amarelo

Amarelo

Amarelo

Amarelo

Amarelo

Amarelo

Amarelo

Honey Dew 
FACULDADE DE AGRONOMIA E MEDICINA VETERINÁRIA

Programa de Pós Graduação em Agronomia

34

35

Número

\begin{tabular}{|c|c|c|}
\hline 36 & CNPH 05-1009 (15/00) & Pele de Sapo \\
\hline 37 & Sancho & Pele de Sapo \\
\hline 38 & Medellin & Pele de Sapo \\
\hline 39 & Grand Prix & Pele de Sapo \\
\hline 40 & Ricura & Pele de Sapo \\
\hline 41 & CNPH 05-1006 (AF2067) & Pele de Sapo \\
\hline 42 & Araguaia & Amarelo \\
\hline 43 & Mel 22 & Amarelo \\
\hline 44 & G1-1 & Amarelo \\
\hline 45 & CNPH 11-1066 & PI \\
\hline 46 & CNPH 11-1072 & PI \\
\hline 47 & CNPH 11-1075 & PI \\
\hline 48 & CNPH 11-1077 & PI \\
\hline 49 & CNPH 11-1076 & PI \\
\hline 50 & CNPH 11-1070 & PI \\
\hline 51 & CNPH 11-1069 & PI \\
\hline 52 & CNPH 11-1073 & PI \\
\hline 53 & CNPH 11-1067 & PI \\
\hline 54 & CNPH 11-1063 & PI \\
\hline 55 & CNPH 11-1065 & PI \\
\hline 56 & CNPH 11-1064 & PI \\
\hline 57 & CNPH 11-1062 & PI \\
\hline 58 & CNPH 11-1061 & PI \\
\hline 59 & CNPH 08-1049 (Melão Itália) & Amarelo \\
\hline 60 & CNPH 11-1058 & PI \\
\hline
\end{tabular}

Athenas

Asturia

Cultivar

Honey Dew

Pele de Sapo

Tipo

Pele de Sapo

Pele de Sapo

Pele de Sapo

PI

PI

Amarelo

PI

Tabela 9: Lista de melões Cantaloupensis utilizados nesse estudo. Número: Número atribuído ao acesso; Cultivar: Nome da cultivar; Tipo: Tipo varietal. 
FACULDADE DE AGRONOMIA E MEIDICINA VETERINÁRIA

Programa de Pós Graduação em Agronomia

\begin{tabular}{|c|c|c|}
\hline Número & Cultivar & Tipo \\
\hline 61 & Estoril & Gália \\
\hline Número & Cultivar & Tipo \\
\hline 62 & Olimpic Express & Cantaloupe \\
\hline 63 & Magisto & Charentais \\
\hline 64 & CNPH 88-441 (Edisto 47) & Cantaloupe \\
\hline 65 & CNPH 88-453 (PMR-45) & Cantaloupe \\
\hline 66 & CNPH 85-245 (Bellegard) & Cantaloupe \\
\hline 67 & CNPH 93-689 (Caroline) & Caipira \\
\hline 68 & CNPH 93-691 (Irene) & Caipira \\
\hline 69 & CNPH 93-692 (Neve) & Caipira \\
\hline 70 & CNPH 63-690 (Catucho) & Caipira \\
\hline 71 & CNPH 04-980 (Melão Gaucho) & Caipira \\
\hline 72 & Caribbean Dream & Harper \\
\hline 73 & Florentino & Harper \\
\hline 74 & Caribbean Gold & Harper \\
\hline 75 & CNPH 01-933 (Cristobal) & Net \\
\hline 76 & CNPH 05-1012 (Torreon) & Cantaloupe \\
\hline 77 & Guaporé & Gália \\
\hline 78 & CNPH 05-1018 (Cyro) & Gália \\
\hline 79 & Maclaren & Gália \\
\hline 80 & 06-1044 (Melão de Cheiro) & Caipira \\
\hline 81 & Glory & Gália \\
\hline 82 & Amaregal & Gália \\
\hline 83 & Deni & Gália \\
\hline 84 & Banzai & Charentais \\
\hline 85 & CNPH 05-1013 (Magrite) & Charentais \\
\hline 86 & Fantasy & Net \\
\hline 87 & Louis & Net \\
\hline 88 & CNPH 00-885 (Mission) & Net \\
\hline 89 & CNPH 05-1011 (RML0031) & Net \\
\hline
\end{tabular}


FACULDADE DE AGRONOMIA E MEDICINA VETERINÁRIA

Programa de Pós Graduação em Agronomia

\subsection{Extração do DNA genômico}

O DNA genômico foi extraído utilizando-se o protocolo de extração CTAB $2 \%$ (FERREIRA \& GRATTAPAGLIA, 1998; BUSO, 2005 - com modificações). Foram utilizadas folhas das plântulas e essa fase envolveu 6 etapas: (1): Foram utilizados aproximadamente $200 \mathrm{mg}$ de tecido foliar pesados em balança de precisão, identificadas e individualizadas em tubos tipo eppendorf com "beads" de cerâmica. Foi adicionado $700 \mu \mathrm{L}$ de detergente catiônico CTAB 2\% - Cationic hexadecyl trimethyl ammonium bromide Cetiltrimetilamônio brometo - ( 1,4 NaCl, 20 mM; EDTA 100 mM; Tris-HCl pH 8,0; PVP $1 \%$ ), responsável pela lise das membranas celulares e $2 \mu \mathrm{L}$ de $\beta$ - mercaptoetanol $0,2 \%$, responsável pela inibição da oxidação do material vegetal. A maceração mecânica para a lise das paredes e membranas celulares foi realizada em máquina "fast-prep". (2): A suspensão obtida foi submetida à temperatura de $65^{\circ} \mathrm{C}$ em banho maria por aproximadamente 1 hora, agitando suavemente os eppendorfs, de 10 em 10 minutos, para solubilização e homogeneização. (3): Após banho maria, foram adicionados $600 \mu \mathrm{L}$ de CIA - Solvente orgânico (solução de clorofórmio e álcool isoamílico 24:1). Os tubos foram agitados por inversão durante 5 minutos e submetidos à centrifugação a 12.000 rpm por 10 minutos. Nessa etapa, a fase orgânica (inferior) contendo parede celular, celulose, lipídeos, proteínas e polissacarídeos, foi separada da fase aquosa (superior) contendo DNA e RNA. (4): A fase superior foi retirada com auxílio de pipeta de $200 \mu \mathrm{L}$ e transferida para outro eppendorf devidamente identificado. Foi adicionado $400 \mu \mathrm{L}$ de isopropanol gelado $\left(-20^{\circ} \mathrm{C}\right)$, responsável pela precipitação dos ácidos nucléicos totais, e os tubos ficaram armazenados em freezer $20^{\circ} \mathrm{C}$ por uma hora. Após esse período, foi realizada centrifugação a $12.000 \mathrm{rpm}$ por 15 minutos, havendo formação do pellet. (5): O sobrenadante foi descartado cuidadosamente para não se perder o pellet. O pellet foi lavado com $500 \mu \mathrm{L}$ de etanol $70 \%$ duas vezes e posteriormente com $500 \mu \mathrm{L}$ etanol $100 \%$ uma vez, e seco em centrífuga a vácuo por 15 minutos. (6): Adicionou-se $50 \mu \mathrm{L}$ de tampão TE (Tris-EDTA) para ressuspender o pellet e $2 \mu \mathrm{L}$ de RNase $(10 \mathrm{mg} / \mathrm{mL})$, incubando as amostras em estufa a $37^{\circ} \mathrm{C}$ por 30 minutos para digestão o RNA restando apenas o DNA genômico desejado. 
FACULDADE DE AGRONOMIA E MEDICINA VETERINÁRIA

Programa de Pós Graduação em Agronomia

2.3 Quantificação e diluição do DNA obtido

Para verificar a quantidade e qualidade do DNA extraído, o mesmo foi quantificado por meio de eletroforese horizontal em gel de agarose $1 \%$ contendo brometo de etídeo. Foi utilizado DNA $\lambda$ com concentração de 200 e 400 ng (total) como comparativo para o DNA concentrado. A diluição do DNA foi feita com água, utilizando-se o cálculo a seguir:

$\mathrm{C}_{1} \times \mathrm{V}_{1}=\mathrm{C}_{2} \times \mathrm{V}_{2}$

Onde:

$\mathrm{C}_{1}=$ Concentração do DNA estimada no gel.

$\mathrm{C}_{2}=$ Volume de água a ser adicionado para concentração de trabalho $(3 \mathrm{ng} / \mu \mathrm{L})$.

$\mathrm{C}_{2}=$ Concentração do DNA para trabalho $(3 \mathrm{ng} / \mu \mathrm{L})$.

$\mathrm{V}_{2}=$ Volume estipulado de DNA para trabalho $(200 \mu \mathrm{L})$.

O DNA diluído foi quantificado em gel de agarose $1 \%$ utilizando DNA $\lambda$ com concentração de 15, 30 e 50 ng (total) como comparativo e os ajustes e requantificação foram feitos quantas vezes necessário até a obtenção da concentração de $3 \mathrm{ng} / \mu \mathrm{L}$. A visualização das bandas decorrentes da quantificação foi realizada por leitura da intensidade de fluorescência do brometo de etídeo sob luz ultravioleta (UV) em transiluminador e fotografada em fotodocumentador. O brometo de etídeo é um corante que se intercala nas moléculas dos ácidos nucléicos sendo que a luz ultravioleta induz a fluroscência.

\subsection{Reações e amplificação da PCR}

Para a realização das reações de PCR para os marcadores SSR foram utilizados 3 $\mu \mathrm{L}$ de DNA a aproximadamente $3 \mathrm{ng} ; 3 \mu \mathrm{L}$ de primer (oligonucleotídeos desenhados para serem complementares à sequência alvo) a $0,9 \mu \mathrm{M}$ e $7 \mu \mathrm{L}$ de mix totalizando $13 \mu \mathrm{L}$ de reação.

Os primers SSR que foram utilizados para as reações foram desenvolvidos por RITSCHEL et al., (2004) e OHSE et al., (2005), no Laboratório de Genética da Embrapa Recursos Genéticos e Biotecnologia. Foram utilizados os primers $\mathrm{F}$ e R (forward e reverse) 
FACULDADE DE AGRONOMIA E MEIDICINA VETERINÁRIA

Programa de Pós Graduação em Agronomia

testados e otimizados em "pré-seleção" (com número de genótipos reduzido) para as linhagens analisadas no capítulo 1 deste trabalho, de acordo com a ocorrência de polimorfismos, para reações com todos os genótipos, diluídos em água à $0,9 \mu \mathrm{M}$. Para tanto, ambos $(\mathrm{F}+\mathrm{R})$ foram diluídos em TE pH 8,0 (Tris-EDTA) à $100 \mu \mathrm{M}$. Na Tabela 10 encontramse os primers SSR polimórficos com suas respectivas sequências (forward e reverse) e temperaturas de anelamento otimizadas, utilizados para as reações com todos os acessos de melão analisados nesse estudo.

Tabela 10: Lista com as sequências (forward e reverse) e temperaturas de anelamento otimizadas dos primers SSR polimórficos utilizados para as reações com todos os acessos de melão analisados.

\begin{tabular}{|c|c|c|}
\hline $\begin{array}{l}\text { Marcador } \\
\text { SSR }\end{array}$ & Sequência forward e reverse & $\begin{array}{c}\text { Temperatura } \\
\text { de } \\
\text { Anelamento }\end{array}$ \\
\hline CM8 & $\begin{array}{l}\text { F5'-TTTCACTTTTTCCCGCCG-3' } \\
\text { R5'-AATGGAAAAGGGAAGTGCAA-3' }\end{array}$ & $56^{\circ} \mathrm{C}$ \\
\hline CM14 & 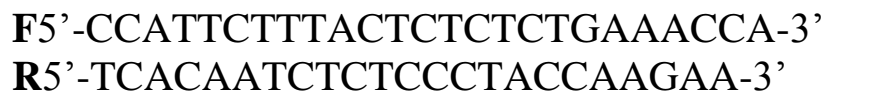 & $58^{\circ} \mathrm{C}$ \\
\hline CM15 & $\begin{array}{l}\text { F5'-TATGAAGCGCGCATAAACAG-3' } \\
\text { R5'-CGAATGTGAAATCTCTTCTCCC-3', }\end{array}$ & $58^{\circ} \mathrm{C}$ \\
\hline $\mathrm{CM} 25$ & $\begin{array}{l}\text { F5'- TGGGGTTGTCAATACAGCAA } \\
\text { R5'-GGAGTGCGTGGAATGTACG-3, }\end{array}$ & $58^{\circ} \mathrm{C}$ \\
\hline CM33 & $\begin{array}{l}\text { F5'-TGATCATCTACTTTTACACCATTCTTT-3' } \\
\text { R5'-TCACAATCTCTCCCTACCAAGA-3' }\end{array}$ & $58^{\circ} \mathrm{C}$ \\
\hline CM40 & $\begin{array}{l}\text { F5'-CGACAATCACGGGAGAGTTT-3' } \\
\text { R5'-TTGTTGCATCAAACTAACACAATC-3' }\end{array}$ & $56^{\circ} \mathrm{C}$ \\
\hline CM43 & $\begin{array}{l}\text { F5'-AGAGATGCTCCCTACACTGC-3' } \\
\text { R5'-TCAAGCAAACCCTAATCGGT-3' }\end{array}$ & $56^{\circ} \mathrm{C}$ \\
\hline CM51 & $\begin{array}{l}\text { F5'-CGACAATCACGGGAGAGTTT-3' } \\
\text { R5'-TTGTTGCATCAAACTAACACAATC-3' }\end{array}$ & $58^{\circ} \mathrm{C}$ \\
\hline CM64 & $\begin{array}{l}\text { F5'-ATACAGCAGATCCACAGGGG-3' } \\
\text { R5'-ATGGGAGTGTGTGGGATGTA-3' }\end{array}$ & $54^{\circ} \mathrm{C}$ \\
\hline
\end{tabular}


FACULDADE DE AGRONOMIA E MEDICINA VETERINÁRIA

Programa de Pós Graduação em Agronomia

$\begin{array}{cc} & \text { F5'-GGTATTATTTGCCCCCACCT-3' } \\ \text { CM72 } & \text { R5'-TGAAGAGTAGGGATGAGTGTGAGA-3' } \\ & \text { Sequência forward e reverse } \\ \text { Marcador } & \\ \text { SSR } & \end{array}$

$58^{\circ} \mathrm{C}$

Temperatura de

Anelamento

F5'-CGGACAAATCCCTCTCTGAA-3'

CM83 R5'-GAACAAGCAGCCAAAGACG-3'

$56^{\circ} \mathrm{C}$

F5'-TCATCTCATTCTCATTCTTCCTCT-3' $\quad 58^{\circ} \mathrm{C}$

CM89 R5'-TGAGGTTTATGAGTGTGTGGTTTT-3'

F5'-CAAAAGGAAAAGAAAAAGACCAAA-3' $\quad 59^{\circ} \mathrm{C}$

CM104 R5'-GGTATTATTTGCCCCCACCT-3'

F5'-TATGAAGCGCGCATAAACAG-3'

CM107 R5'-CGAATGTGAAATCTCTTCTCCC-3'

$56^{\circ} \mathrm{C}$

F5'-GGGTTTGGGGTTGTGAC-3'

$54^{\circ} \mathrm{C}$

CM116 R5'-CGCACTTTGTTTATTCCTCAA-3'

F5'-CTTCTCTCTCAATGCATAACCA-3'

CM125 R5'-AACCCAGAAGGAGAAGTACAA-3'

$54^{\circ} \mathrm{C}$

F5'-GTTTGGCCTTGAGAAGGTGA-3'

CM128 R5'-AGGCCCATAAAGTTGTGTGT-3'

$59^{\circ} \mathrm{C}$

F5'-CTCCCCCACCTAAATGGC-3'

$56^{\circ} \mathrm{C}$

CM139 R5'-CGAGTAATGAGGGGCAGAAG-3'

F5'-GCGCAAACCACAGAGAAGAT-3'

M161 R5'-GCATAGGGAACTTGCCAGAG-3'

$56^{\circ} \mathrm{C}$

F5'-TCACCAAACCCTAACACACAA-3'

$56^{\circ} \mathrm{C}$

CM176 R5'-TGGGGATATTCGGATGAAAA-3'

F5'-TGGAATGAAATGATTGAGAGGTT-3' $\quad 56^{\circ} \mathrm{C}$

CM177 R5'-ATCTCCCTATCCCCACCATA-3'

F5'-GCTTTTGCTCTATTTTCTTCTTCTT-3' $\quad 56^{\circ} \mathrm{C}$

CM185 R5'-GGCTTGGTAACCGAAGATCC-3'

F5'-TGACATCCACCCAGACTCAT-3'

$56^{\circ} \mathrm{C}$

CM197 R5'-CAGAGACACGAAGAGAAAGAGG-3'

$\begin{array}{ll}\text { CM224 } & \text { F5'-AAGAGAGCTTTCGCCTGTTC-3' } \\ & \text { R5'-GAGATTTGCAAGTCGAAAAAA-3' }\end{array}$ 
FACULDADE DE AGRONOMIA E MEDICINA VETERINÁRIA

Programa de Pós Graduação em Agronomia

\begin{tabular}{|c|c|c|}
\hline $\begin{array}{l}\text { Marcador } \\
\quad \text { SSR }\end{array}$ & Sequência forward e reverse & $\begin{array}{c}\text { Temperatura } \\
\text { de } \\
\text { Anelamento }\end{array}$ \\
\hline CM227 & $\begin{array}{l}\text { F5'-AGAGACCTCTCCCACCCATT-3' } \\
\text { R5'-CGGTCTTCTTTGTTGTAAGTTGT-3' }\end{array}$ & $56^{\circ} \mathrm{C}$ \\
\hline CM230 & $\begin{array}{l}\text { F5'-ACACAAGACGTCTCAGAACTGC-3' } \\
\text { R5'-CAAAAAGCATCAAAATGGTTG-3' }\end{array}$ & $56^{\circ} \mathrm{C}$ \\
\hline CM244 & $\begin{array}{l}\text { F5'-CAGCAGATGACCAAACCAAA-3' } \\
\text { R5'-CGTTATGAGGATAAGGGAGAAA-3' }\end{array}$ & $56^{\circ} \mathrm{C}$ \\
\hline CM245 & $\begin{array}{l}\text { F5'-CCAAATACGACCAAAAGTTCC-3' } \\
\text { R5'-CACACGTTGTATTCCAGTCA-3' }\end{array}$ & $56^{\circ} \mathrm{C}$ \\
\hline CM248 & $\begin{array}{l}\text { F5'-CCACCTCTCTCAATGTAAGCA-3' } \\
\text { R5'-GGTCCAGACCAGAAACAAAA-3' }\end{array}$ & $56^{\circ} \mathrm{C}$ \\
\hline CM254 & $\begin{array}{l}\text { F5'-TACAGACACGCCTTCACCTG-3' } \\
\text { R5'-ACCAAATACGCCCAAATGTT-3' }\end{array}$ & $56^{\circ} \mathrm{C}$ \\
\hline CM303 & $\begin{array}{l}\text { F5'-CTGCAAGTGCGGTGACAACT-3' } \\
\text { R5'-TCGAACACAATCTCCACTTAAGAA-3' }\end{array}$ & $56^{\circ} \mathrm{C}$ \\
\hline CM305 & $\begin{array}{l}\text { F5'-GCAAACCCACCAAATTTCC-3' } \\
\text { R5'-AGAACATGGAATTGGGAATCG-3' }\end{array}$ & $56^{\circ} \mathrm{C}$ \\
\hline CM311 & $\begin{array}{l}\text { F5'-GACTCAACAAACCCATCAAAAA-3' } \\
\text { R5'-AGTTTGTCGTCGTCGGGAAT-3' }\end{array}$ & $56^{\circ} \mathrm{C}$ \\
\hline CM319 & $\begin{array}{l}\text { F5'-AAGATGGAGATGAGTTGGCAAT-3' } \\
\text { R5'-GAGCTCAATGTTCCTATTGGTTT-3' }\end{array}$ & $56^{\circ} \mathrm{C}$ \\
\hline CM320 & $\begin{array}{l}\text { F5'-TGGAGAAAGAAAAACTGAGCTG-3' } \\
\text { R5'-GAACCCCATAAACACATCCAA-3' }\end{array}$ & $56^{\circ} \mathrm{C}$ \\
\hline CM321 & $\begin{array}{l}\text { F5'-GGCGTTTCTCTCTGGTTTCA-3' } \\
\text { R5'-CTAAGCCTCGGACTCCTCAA-3' }\end{array}$ & $56^{\circ} \mathrm{C}$ \\
\hline CM331 & $\begin{array}{l}\text { F5'-CAACATCAAGCATCAGAAGCA-3' } \\
\text { R5'-AAACTTAAGCTTCCAACCTCCT-3' }\end{array}$ & $56^{\circ} \mathrm{C}$ \\
\hline CM335 & $\begin{array}{l}\text { F5'-TCCTGAACAACGACGTCAAA-3' } \\
\text { R5'-CAATGCAAGCAGTTTAAAGAGTAA-3' }\end{array}$ & $56^{\circ} \mathrm{C}$ \\
\hline
\end{tabular}


FACULDADE DE AGRONOMIA E MEDICINA VETERINÁRIA

Programa de Pós Graduação em Agronomia

\begin{tabular}{|c|c|c|}
\hline CM336 & $\begin{array}{l}\text { F5'-CCAAATCTCTCCCCCACATA-3' } \\
\text { R5'-TGTTTTAAATTTTGGGGTTTAACT-3' }\end{array}$ & $56^{\circ} \mathrm{C}$ \\
\hline $\begin{array}{l}\text { Marcador } \\
\quad \text { SSR }\end{array}$ & Sequência forward e reverse & $\begin{array}{c}\text { Temperatura } \\
\text { de } \\
\text { Anelamento }\end{array}$ \\
\hline CM337 & $\begin{array}{l}\text { F5'-ATGGCCATGAGATGGAAAAC-3' } \\
\text { R5'-TGTAGGAGGCCAATTTCACA-3' }\end{array}$ & $56^{\circ} \mathrm{C}$ \\
\hline CM342 & $\begin{array}{l}\text { F5'-TTCCATTAATCATCTCCTCCAAA-3' } \\
\text { R5'-CTCAGTGTAAGTTGCTGGGAAA-3' }\end{array}$ & $56^{\circ} \mathrm{C}$ \\
\hline CM347 & 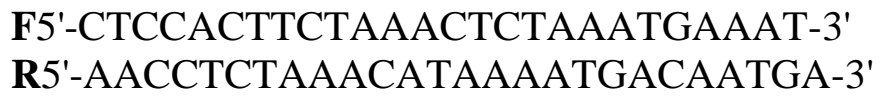 & $56^{\circ} \mathrm{C}$ \\
\hline CM351 & $\begin{array}{l}\text { F5'-AACCCACAACAACACCAACA-3' } \\
\text { R5'-TTTTTGTAAATGAGTTGATTGATGA-3' }\end{array}$ & $56^{\circ} \mathrm{C}$ \\
\hline CM354 & $\begin{array}{l}\text { F5'-TTCCATTAATCATCTCCTCCAAA-3' } \\
\text { R5'-CTCAGTGTAAGTTGCTGGGAAA-3' }\end{array}$ & $56^{\circ} \mathrm{C}$ \\
\hline
\end{tabular}

Para as reações de PCR, foi utilizado o mix de reagentes a seguir: 2,65 $\mu \mathrm{L}$ de água; $1,30 \mu \mathrm{L}$ de dNTP a $2,5 \mu \mathrm{M} ; 1,30 \mu \mathrm{L}$ de BSA a $2,5 \mathrm{ng} / \mathrm{mL} ; 1,30 \mu \mathrm{L}$ de tampão $10 \mathrm{x}$ contendo $100 \mu \mathrm{M}$ Tris- $\mathrm{HCl} \mathrm{pH} 8,3 ; 500 \mu \mathrm{M} \mathrm{KCl} ; 0,25 \mu \mathrm{L}$ de $\mathrm{MgCl}_{2} 50 \mathrm{mM}$ e 0,20 $\mu \mathrm{L}$ de Taq DNA polimerase a 5,0 U/ $\mu \mathrm{L}$.

As condições de amplificação a que foram submetidos os produtos acima no termociclador, foram as seguintes: Um ciclo inicial de 5 minutos a $94^{\circ} \mathrm{C}$, seguido de 30 ciclos de 1 minuto a $94^{\circ} \mathrm{C}, 1$ minuto na temperatura de anelamento (otimizada para cada primer variando de 52 a $60^{\circ} \mathrm{C}$ ), e 1 minuto a $72^{\circ} \mathrm{C}$, seguidos de um ciclo final de 10 minutos a $72^{\circ} \mathrm{C}$.

A separação dos fragmentos obtidos a partir de PCR foi realizada por meio de eletroforese vertical em gel de poliacrilamida 5\%, coloração com nitrato de prata $\left(\mathrm{AgNO}_{3}\right)$ e revelação com carbonato de sódio anidro $\left(\mathrm{Na}_{2} \mathrm{CO}_{3}\right)$, a uma constante de $90 \mathrm{~W}$ de potência. Optou-se por utilizar a eletroforese em gel de poliacrilamida $5 \%$, devido à sensibilidade e especificidade na separação de macromoléculas. O tamanho dos fragmentos amplificados em pares de base foi avaliado por comparação com marcador de peso molecular: Ladder 10pb. 
FACULDADE DE AGRONOMIA E MEDICINA VETERINÁRIA

Programa de Pós Graduação em Agronomia

2.5 Análise estatística dos marcadores gerados

A análise para os marcadores microssatélites foi codificada na forma x/y (tamanho de cada alelo no loco) e os dados de genotipagem das 73 cultivares foram analisados por meio do uso do software CERVUS Versão 3.0.3 (MARSHALL et al., 1998; KALINOWSKI et al., 2007), que forneceu dados como o número de genótipos observados em cada loco (N), o número de alelos por loco $(\mathrm{K})$, heterozigosidade observada (Ho), e heterozigosidade esperada (He), Polymorphism Information Content (PIC) e as probabilidades de não exclusão do parental 1 (NE-1P) e 2 (NE2P).

A heterozigosidade de um marcador é a probabilidade de um indivíduo ser heterozigoto no loco marcador e depende do número de alelos no loco e de sua frequência na população. A Ho foi calculada utilizando-se a proporção entre os genótipos heterozigotos individuais e o número total de heterozigotos analisados em cada loco, sendo que, quanto mais próximo de zero, maior será a proporção de homozigotos para o loco em questão. A He foi estimada com base na probabilidade de dois indivíduos tomados ao acaso, em uma dada amostra apresentarem alelos diferentes em um loco (NEI, 1987). O PIC trata-se de um estimador que reflete tanto o número de alelos como a frequência de cada alelo. Esse estimador reflete o quão informativo o loco apresenta-se, com base no polimorfismo.

Além dos dados acima gerados, o software Cervus realiza uma simulação de paternidade com a probabilidade da não exclusão do parental 1 e do parental 2 entre os genótipos analisados (NE-1P e NE-2P respectivamente). Assim sendo, a probabilidade de exclusão do parental 1 será de: [1-(NE-1P)]x100, e do parental 2: [1-(NE-2P)]x100. Os primers com maiores índices de NE-1P e NE-2P contém os menores índices de PIC, sendo portanto, menos informativos. Assim sendo, esses primers foram excluídos um a um até a obtenção de um número mínimo de primers que fosse útil na distinção das 73 cultivares com índice de 99,99\% de exclusão de parentais.

Os dados de genotipagem das 73 cultivares e dos 15 PIs, foram submetidos ao software NTSYS (ROHLF, 1992), que forneceu índices de similaridade genética entre cada par de acessos. Vários índices são descritos na literatura, mas o coeficiente BAND (Band- 
FACULDADE DE AGRONOMIA E MEDICINA VETERINÁRIA

Programa de Pós Graduação em Agronomia

Sharing Coefficient of Lynch) (LYNCH, 1990) foi o utilizado nesse estudo. Com base nos índices, estabeleceu-se uma matriz de similaridade entre os acessos que serviu de base para as análises de agrupamento e de dispersão dos mesmos (FALEIRO, 2007).

O coeficiente BAND é baseado na soma da proporção de alelos comuns entre dois genótipos divididos pelo dobro do número de alelos testados. A análise de agrupamento é baseada em método hierárquico que utiliza o critério das médias das distâncias entre o vizinho mais próximo (single linkage) e o mais distante (complete linkage). Esse método é conhecido como Unweighted Pair-group Method Using Arithmetic Average ou simplesmente, Método da Ligação Média entre Grupos (UPGMA). Após essa análise, o programa gera o dendrograma dos genótipos analisados, bem como o agrupamento dos mesmos por similaridade genética (FALEIRO, 2007).

\section{RESULTADOS E DISCUSSÃO}

Foram selecionados 44 primers SSR polimórficos para os 73 genótipos das cultivares comerciais por apresentarem bandas bem definidas e mais nítidas (Figura 10).

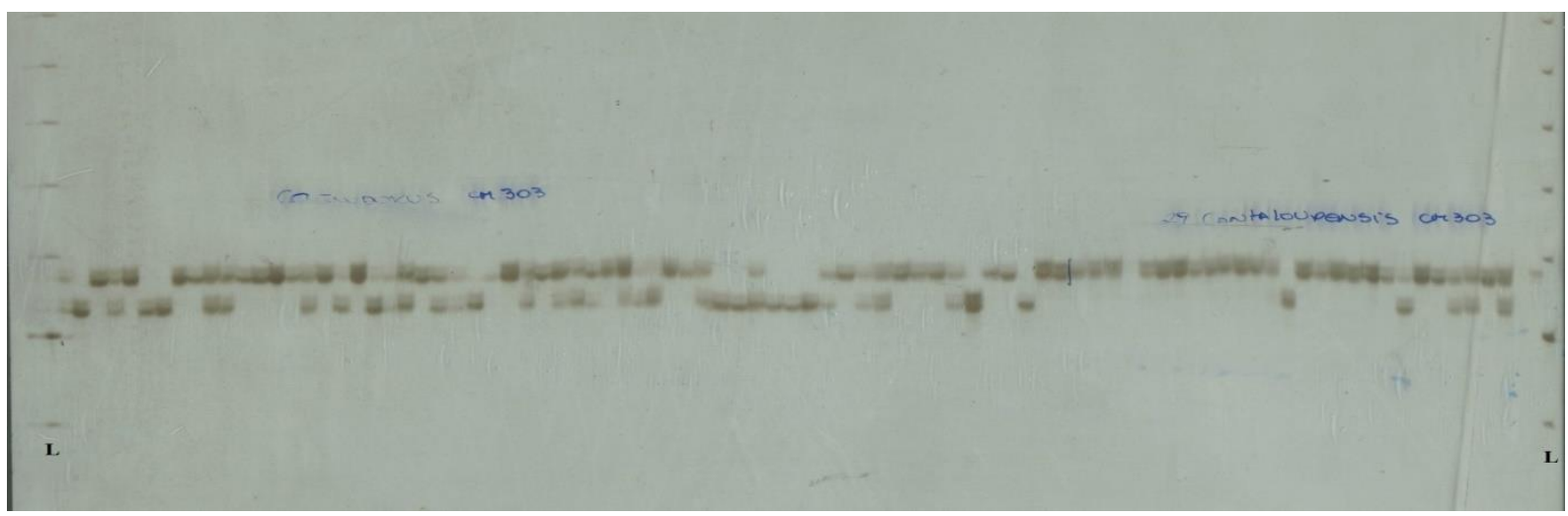

Figura 10: Primer CM303 - Um dos 44 primers SSR polimórficos para as 73 cultivares e os 15PIs; L: Marcador de peso molecular Ladder 10pb.

Os 44 locos polimórficos analisados amplificaram um total de 204 alelos para as 73 cultivares com média de 4,64 alelos por loco (Tabela 11), número de alelos muito superior ao descrito por Aragão (2011), que avaliou 41 acessos de melão utilizando 17 primers, 
FACULDADE DE AGRONOMIA E MEIDICINA VETERINÁRIA

Programa de Pós Graduação em Agronomia

também desenvolvidos por Ritschel et al. (2004), e amplificou 41 alelos. Número de alelos também muito superior ao constatado por Kaçar et al. (2012), que analisaram a diversidade genética de 81 genótipos de melão da Turquia em comparação com 15 genótipos referência obtidos na França, e amplificaram 123 alelos a partir de 20 primers SSR com média de 6,15 alelos por loco, média essa superior a encontrada nesse estudo, indicando uma maior discrepância entre os locos avaliados no que diz respeito ao número de alelos por loco.

Staub et al. (2000) compararam acessos de melão de distintos grupos botânicos (Cantaloupensis, Inodorus, Conomon e Flexuosus) utilizando sete marcadores SSR polimórficos que amplificaram um total de 54 alelos. Adicionalmente, 93 alelos foram detectados em um estudo que avaliou a divergência de 40 acessos de melão pertencentes aos grupos Cantaloupensis, Inodorus e Conomon por meio de 25 marcadores SSR (RITSCHEL et al., 2004). O número de alelos aqui descrito foi inferior ao encontrado por Tzuri et al. (2006), que avaliaram 102 genótipos de vários tipos de melão (Cantaloupe, Charentais, Honey Dew, Ananas, Gália, Inodorus e melão oriental) por meio de PCR e eletroforese em poliacrilamida, e amplificaram um total de 212 alelos utilizando 48 primers SSR polimórficos. Goulão \& Oliveira (2001) avaliaram a similaridade de 41 cultivares comerciais de maçã utilizando 13 marcadores SSR polimórficos que amplificaram um total de 84 alelos.

Utilizando sete marcadores SSR, Jarret et al. (1996) verificaram variação genética entre acessos de melancia, como, Matsum \& Nakaivar. lanatus, C. lanatus (Thunb) Matsum \& Nakai var. citroides (L. H. Bailey) Mansf. e C. colocynthis (L.) Schrad.

Guerra-Sanz (2002) relataram a identificação de 18 marcadores SSR que detectaram polimorfismo entre variedades de melancia, raças locais, C. colocynthis e híbridos interespecíficos. Joobeur et al. (2006) desenvolveram 36 primers SSR que detectaram polimorfismo em oito acessos de melancia e quatro variedades. Kwon et al. (2010) avaliaram 63 pares de primers SSR para discriminar 49 variedades comerciais de melancia Coreanas e Norte Americanas dos quais 30 apresentaram polimorfismo. De acordo com esses autores, existem muitas variedades de melancia que não foram diferenciadas por marcadores SSR. 
FACULDADE DE AGRONOMIA E MEDICINA VETERINÁRIA

Programa de Pós Graduação em Agronomia

Embora marcadores microssatélites estejam disponíveis para melancia, um número mínimo desse tipo de marcador ainda não foi proposto para ajudar na proteção de cultivares e na resolução de disputas comerciais. This et al. (2004) propuseram o mínimo de sete microssatélites para analisar cultivares de uva e alelos de referência estabelecidos.

De acordo com Botstein et al. (1980), o PIC também é indicativo da qualidade do marcador em estudos genéticos. PIC superiores a 0,5 são considerados muito informativos, com valores entre 0,25 e 0,50 mediamente informativos e com valores inferiores a 0,25, pouco informativos. O PIC variou de 0,199 no loco CM305 a 0,799 no loco CM89, este último sendo o loco mais informativo (Tabela 11). O valor médio do PIC de 0,459 se apresentou medianamente informativo para os locos em questão. Henane et al. (2015) demonstraram com 20 marcadores SRR ampla diversidade existente entre variedades de melão (Cucumis melo L.) e (Cucumis melo var. flexuosus) na Tunísia, evidenciado pelo PIC que variou de 0,43 a 0,92, com uma média de 0,454 e o número de alelos por loco variou de dois a três com média de 2,54, concluindo que essas variedades constituem uma reserva importante de diversidade.

O índice de He variou de 0,226 no loco CM305 a 0,828 no loco CM89 com média de 0,520 (Tabela 11). A Ho variou de 0,055 no loco CM244, sendo o loco com maior proporção de homozigotos, a 0,451 no loco CM08, com menos genótipos homozigotos (Tabela 11). O índice de Ho observado condiz com o esperado, já que se tratam de análises de cultivares comerciais, sendo assim, a proporção de homozigotos deve ser baixa.

Tabela 11: Medidas descritivas para estudos de variabilidade baseados nos 44 marcadores SSR polimórficos em 73 cultivares de melão pertencentes aos grupos Inodorus e Cantaloupensis, estimados pelo software CERVUS.

\begin{tabular}{cccccccc}
\hline Loco & K & N & Ho & He & PIC & NE-1P & NE-2P \\
\hline CM303 & 2 & 73 & 0,342 & 0,394 & 0,315 & 0,923 & 0,843 \\
CM248 & 3 & 73 & 0,164 & 0,590 & 0,497 & 0,828 & 0,708 \\
CM230 & 4 & 73 & 0,219 & 0,497 & 0,407 & 0,877 & 0,776 \\
CM244 & 4 & 73 & 0,055 & 0,382 & 0,330 & 0,928 & 0,821
\end{tabular}


FACULDADE DE AGRONOMIA E MEIDICINA VETERINÁRIA

Programa de Pós Graduação em Agronomia

\begin{tabular}{|c|c|c|c|c|c|c|c|}
\hline Loco & $\mathbf{K}$ & $\mathbf{N}$ & Но & He & PIC & NE-1P & NE-2P \\
\hline CM331 & 2 & 73 & 0,068 & 0,367 & 0,298 & 0,934 & 0,851 \\
\hline CM354 & 4 & 73 & 0,247 & 0,262 & 0,233 & 0,966 & 0,879 \\
\hline CM245 & 3 & 73 & 0,137 & 0,516 & 0,430 & 0,869 & 0,758 \\
\hline CM337 & 4 & 73 & 0,137 & 0,557 & 0,456 & 0,845 & 0,740 \\
\hline CM336 & 5 & 72 & 0,153 & 0,508 & 0,446 & 0,867 & 0,734 \\
\hline CM40 & 5 & 73 & 0,137 & 0,628 & 0,565 & 0,788 & 0,632 \\
\hline CM51 & 7 & 73 & 0,110 & 0,776 & 0,735 & 0,623 & 0,444 \\
\hline CM320 & 5 & 73 & 0,356 & 0,485 & 0,414 & 0,881 & 0,763 \\
\hline CM254 & 7 & 73 & 0,192 & 0,674 & 0,635 & 0,729 & 0,547 \\
\hline CM321 & 2 & 73 & 0,123 & 0,248 & 0,216 & 0,970 & 0,892 \\
\hline CM305 & 2 & 70 & 0,029 & 0,226 & 0,199 & 0,975 & 0,901 \\
\hline CM177 & 6 & 72 & 0,097 & 0,632 & 0,554 & 0,791 & 0,649 \\
\hline CM25 & 6 & 73 & 0,137 & 0,722 & 0,668 & 0,701 & 0,529 \\
\hline CM43 & 4 & 73 & 0,123 & 0,638 & 0,581 & 0,781 & 0,617 \\
\hline CM161 & 5 & 73 & 0,123 & 0,417 & 0,382 & 0,910 & 0,773 \\
\hline CM227 & 5 & 73 & 0,288 & 0,551 & 0,463 & 0,846 & 0,729 \\
\hline CM125 & 7 & 73 & 0,274 & 0,503 & 0,462 & 0,865 & 0,711 \\
\hline CM342 & 5 & 73 & 0,123 & 0,458 & 0,427 & 0,888 & 0,736 \\
\hline CM33 & 5 & 72 & 0,306 & 0,561 & 0,483 & 0,838 & 0,709 \\
\hline CM176 & 5 & 73 & 0,315 & 0,549 & 0,457 & 0,849 & 0,736 \\
\hline CM64 & 7 & 73 & 0,123 & 0,646 & 0,595 & 0,764 & 0,595 \\
\hline CM335 & 2 & 73 & 0,082 & 0,388 & 0,311 & 0,926 & 0,845 \\
\hline CM311 & 2 & 71 & 0,085 & 0,420 & 0,330 & 0,913 & 0,835 \\
\hline CM319 & 2 & 73 & 0,219 & 0,295 & 0,250 & 0,957 & 0,875 \\
\hline CM224 & 5 & 73 & 0,219 & 0,366 & 0,343 & 0,931 & 0,797 \\
\hline CM197 & 7 & 72 & 0,194 & 0,662 & 0,606 & 0,751 & 0,585 \\
\hline CM139 & 4 & 73 & 0,288 & 0,558 & 0,455 & 0,846 & 0,742 \\
\hline CM128 & 4 & 72 & 0,347 & 0,421 & 0,356 & 0,912 & 0,807 \\
\hline CM14 & 8 & 72 & 0,306 & 0,646 & 0,585 & 0,765 & 0,605 \\
\hline CM107 & 5 & 71 & 0,183 & 0,714 & 0,658 & 0,713 & 0,542 \\
\hline
\end{tabular}


FACULDADE DE AGRONOMIA E MEIDICINA VETERINÁRIA

Programa de Pós Graduação em Agronomia

\begin{tabular}{cccccccc} 
Loco & K & N & Ho & He & PIC & NE-1P & NE-2P \\
\hline CM116 & 3 & 72 & 0,194 & 0,375 & 0,321 & 0,931 & 0,829 \\
CM104 & 7 & 72 & 0,153 & 0,659 & 0,616 & 0,744 & 0,567 \\
CM83 & 3 & 68 & 0,250 & 0,530 & 0,426 & 0,862 & 0,765 \\
CM89 & 9 & 69 & 0,116 & 0,828 & 0,799 & 0,524 & 0,351 \\
CM72 & 8 & 69 & 0,130 & 0,699 & 0,656 & 0,704 & 0,525 \\
CM15 & 6 & 72 & 0,250 & 0,666 & 0,598 & 0,762 & 0,606 \\
CM08 & 3 & 71 & 0,451 & 0,641 & 0,564 & 0,797 & 0,651 \\
CM351 & 4 & 73 & 0,110 & 0,291 & 0,270 & 0,958 & 0,849 \\
CM185 & 5 & 72 & 0,194 & 0,449 & 0,422 & 0,892 & 0,738 \\
CM347 & 3 & 71 & 0,366 & 0,502 & 0,381 & 0,876 & 0,806 \\
\hline Média & 4,64 & 72,2 & 0,193 & 0,520 & 0,459 & - & -
\end{tabular}

K: Número de alelos; N: Número de genótipos; Ho: Heterozigosidade observada; He: Heterozigosidade esperada; PIC: Conteúdo de informação polimórfica; NE-1P: Probabilidade de não exclusão do parental 1; NE-2P: Probabilidade de não exclusão do parental 2.

No ano de 1997 foi sancionada a Lei da Proteção de Cultivares no Brasil com o objetivo de fortalecer e padronizar os direitos de propriedade intelectual para quem desenvolve uma cultivar no País. De acordo com a legislação nacional, uma cultivar é a variedade de qualquer gênero ou espécie vegetal que seja claramente distinguível das cultivares já conhecidas por uma margem mínima de descritores, geralmente morfológicos, porém, os marcadores moleculares têm sido aceitos para diferenciação de cultivares e estudos com esse âmbito têm sido cada vez mais realizados.

Os primers com maiores índices de NE-1P, NE-2P e menores índices de PIC (CM303, CM230, CM244, CM331, CM354, CM245, CM337, CM336, CM321, CM305, CM161, CM227, CM125, CM342, CM335, CM311, CM319, CM221, CM139, CM128, CM116, CM83, CM351, CM185 E CM347) foram excluídos um a um e foi identificado um conjunto de 17 primers (CM248, CM40, CM51, CM254, CM177, CM25, CM43, CM33, CM64, CM197, CM14, CM107, CM104, CM89, CM72, CM15 e CM08) que foram úteis na distinção das 73 cultivares com índice de 99,99\% de exclusão de parentais. Esses primers podem ser utilizados em pesquisas posteriores com as cultivares analisadas nesse estudo, bem 
FACULDADE DE AGRONOMIA E MEDICINA VETERINÁRIA

Programa de Pós Graduação em Agronomia

como, podem auxiliar na diferenciação das mesmas, sendo importante ferramenta na distinção efetiva e rápida dos genótipos.

Gama et al. (2013) utilizaram 10 primers SSR para caracterizar 17 cultivares de melancia e amplificaram um total de 34 alelos, com análise de similaridade variando de 0,34 a 1 concluindo que os locos não foram o suficiente para distinguir essas cultivares.

Como alternativa para replicação dos marcadores SSR obtidos neste trabalho, sugere-se a amplificação por meio de PCR, e as reações obtidas submetidas à genotipagem em sequenciador, ou à eletroforese em gel de poliacrilamida, aplicando-se as reações em géis multiplex, corados com nitrato de prata e revelados com carbonato de sódio anidro. Para melhor resolução de fragmentos, aplicar no máximo dois primers por gel (Figura 11), respeitando-se a amplitude alélica de 30pb dentro de cada loco e entre os locos e o tempo de revelação de cada loco no gel multiplex sendo próximo.

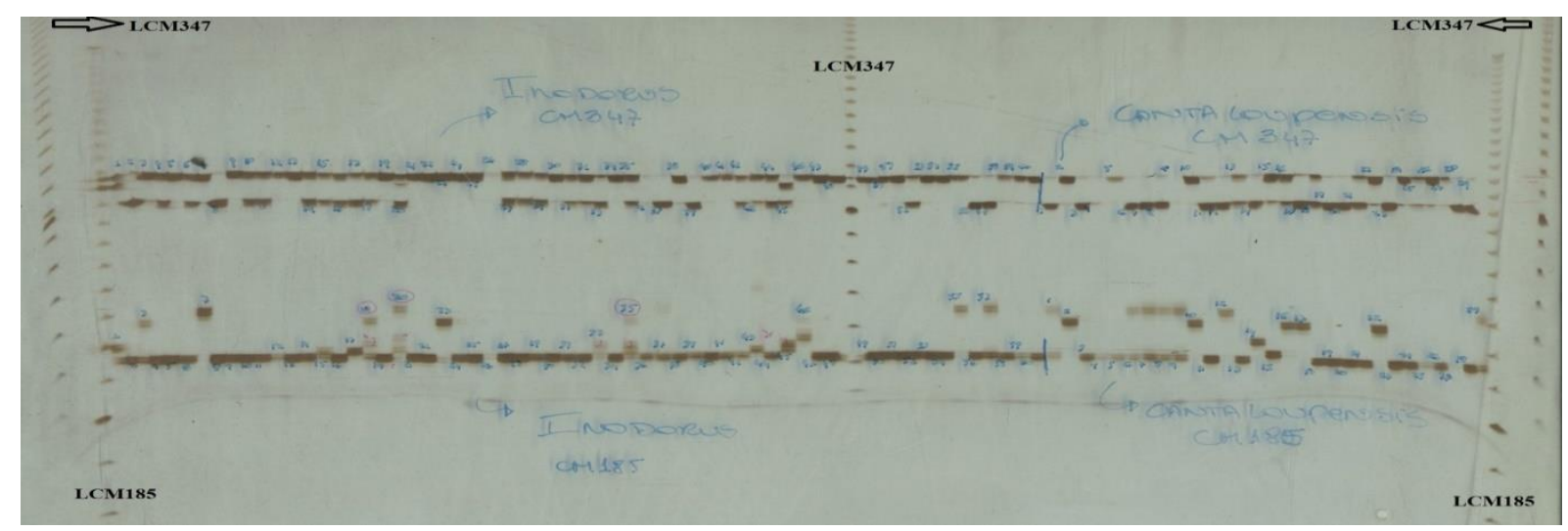

Figura 11: Exemplo de gel duplex com ótima resolução de banda. LCM185: Ladder 10pb para comparação com fragmentos do primer CM185. LCM347: Ladder 10pb para comparação com fragmentos do primer CM347.

Foram gerados dois dendrogramas, um apenas com as 73 cultivares e o outro com as 73 cultivares e os 15 PIs.

O dendrograma resultante da análise SSR para as 73 cultivares (Figura 12) agrupou os genótipos com uma similaridade genética que variou de 0,355 a 0,98. Observou-se o agrupamento dos genótipos em dois principais grupos (1 e 2) com 35,5\% de similaridade 
FACULDADE DE AGRONOMIA E MEDICINA VETERINÁRIA

Programa de Pós Graduação em Agronomia

entre eles. O primeiro grupo apresentou a maioria dos genótipos, e foi subdividido em 2 subgrupos (1.1 e 1.2) com 46,5\% de similaridade entre si. O subgrupo 1.2 apresentou apenas o genótipo 2 (referente ao melão Jangada, tipo Amarelo). As cultivares Potiguar (9) e Goldex (13), ambas pertencentes ao grupo Inodorus, do tipo Amarelo, foram as que apresentaram maior similaridade (98\%), sendo agrupadas no subgrupo 1.1 .

O segundo grupo apresentado foi subdividido em dois subgrupos (2.1 e 2.2). Foi observada similaridade de $43 \%$ entre a cultivar Cristobal (75) grupo Cantaloupensis, tipo Net, e as cultivares Gold Pride (7) e Best Bite (20) ambas Inodorus, tipo Amarelo agrupadas no subgrupo 2.1. O subgrupo 2.2 apresentou apenas as cultivares Iracema (17) e Mel 22 (43), ambas Inodorus, tipo Amarelo, com 52\% de similaridade entre-si.

Dessa forma, pôde ser observado que não houve associação com a classificação dos genótipos no agrupamento. Contudo, a maioria dos genótipos Inodorus agruparam-se no subgrupo A e a maioria dos genótipos Cantaloupensis agruparam-se no subgrupo B, ambos subgrupos do grupo 1. O número de marcadores SSR foi o suficiente para predizer ampla variabilidade genética entre as cultivares estudadas, já que nenhuma delas apresentou similaridade genética igual a 1. Adicionalmente, Garcia et al. (1998) agruparam perfeitamente 32 linhagens de diferentes grupos utilizando marcadores moleculares e caracteres agronômicos. Aragão (2011) usou marcadores microssatélites para avaliar a divergência genética de acessos de melão do Nordeste brasileiro pertencentes aos grupos Cantaloupensis, Inodorus, Momordicae Conomon, e concluiu haver grande variabilidade, entre e dentro dos grupos analisados. 
FACULDADE DE AGRONOMIA E MEDICINA VETERINÁRIA

Programa de Pós Graduação em Agronomia

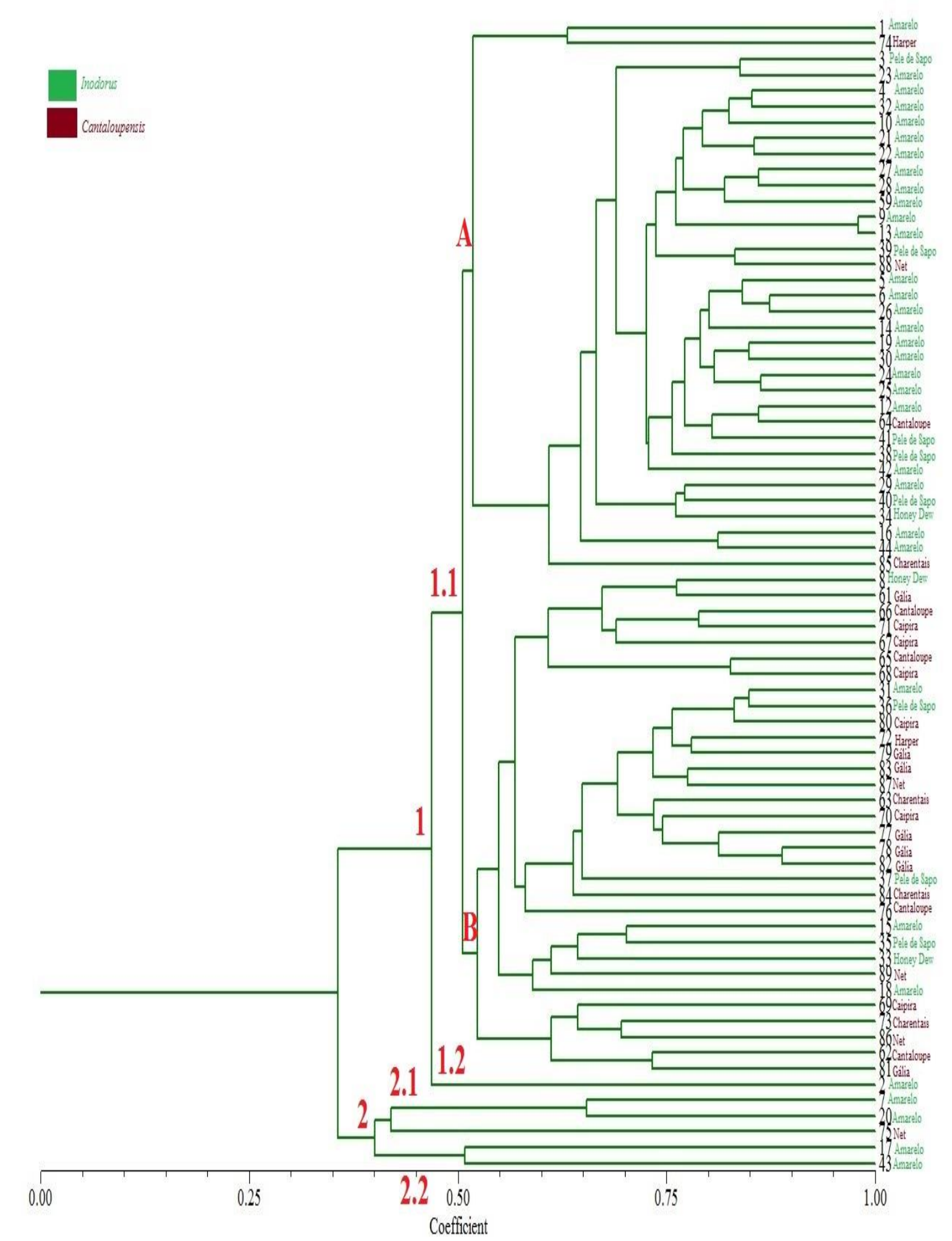

Figura 12: Dendrograma das 73 cultivares gerado a partir da análise de 44 primers SSR. 1 e 2:

Grupos principais; 1.1 e 1.2: Subgrupos do grupo 1; 2.1 e 2.2: Subgrupos do grupo 2 . 
FACULDADE DE AGRONOMIA E MEIDICINA VETERINÁRIA

Programa de Pós Graduação em Agronomia

Informações sobre a diversidade e a distância genética também podem auxiliar na ampliação da base genética durante o desenvolvimento de programas de melhoramento (Freitas \& Bered, 2003). Nesse sentido, 15 PIs foram analisados juntamente com as 73 cultivares. O dendrograma resultante da análise SSR para as 73 cultivares e os 15 PIs (Figura 13) agrupou os genótipos com uma similaridade genética variando de 0,35 a 0,98. Observouse o agrupamento dos genótipos em dois principais grupos (1 e 2) com 35,5\% de similaridade entre eles. O primeiro grupo apresentou a maioria dos genótipos, e foi subdividido em 2 subgrupos (1.1 e 1.2) com 46,5\% de similaridade entre si. O subgrupo 1.2 apresentou novamente apenas o genótipo 2 (referente ao melão Jangada, tipo Amarelo). As cultivares Potiguar (9) e Goldex (13), ambas pertencentes ao grupo Inodorus, do tipo Amarelo, continuaram apresentando a maior similaridade (98\%) e sendo agrupadas no subgrupo 1.1.

O segundo grupo apresentado foi subdividido em dois subgrupos (2.1 e 2.2). Foi observada similaridade de $43 \%$ entre a cultivar Cristobal (75) grupo Cantaloupensis, tipo Net, e as cultivares Gold Pride (7) e Best Bite (20) ambas Inodorus, tipo Amarelo e o PI55 agrupadas no subgrupo 2.1, indicando que esse PI está relacionado geneticamente com essas duas cultivares tipo Amarelo. O subgrupo 2.2 apresentou apenas as cultivares Iracema (17) e Mel 22 (43), ambas Inodorus, tipo Amarelo e os PIs 45 e 46 também revelando maior similaridade genética entre eles.

Novamente não houve associação com a classificação dos genótipos no agrupamento. Contudo, o número de marcadores SSR foi o suficiente para predizer ampla variabilidade genética entre as cultivares estudadas, já que nenhuma delas apresentou similaridade genética igual a 1. Os 15 genótipos PIs (45, 46, 47, 48, 49, 50, 51,52, 53, 54, 55, $56,57,58$ e 60) apresentaram-se bem dispersos com similaridades que se assemelham aos dois grupos estudados (Inodorus e Cantaloupensis). Assim sendo, seria desejável introduções divergentes de acordo com os grupos estudados. 
FACULDADE DE AGRONOMIA E MEDICINA VETERINÁRIA

Programa de Pós Graduação em Agronomia
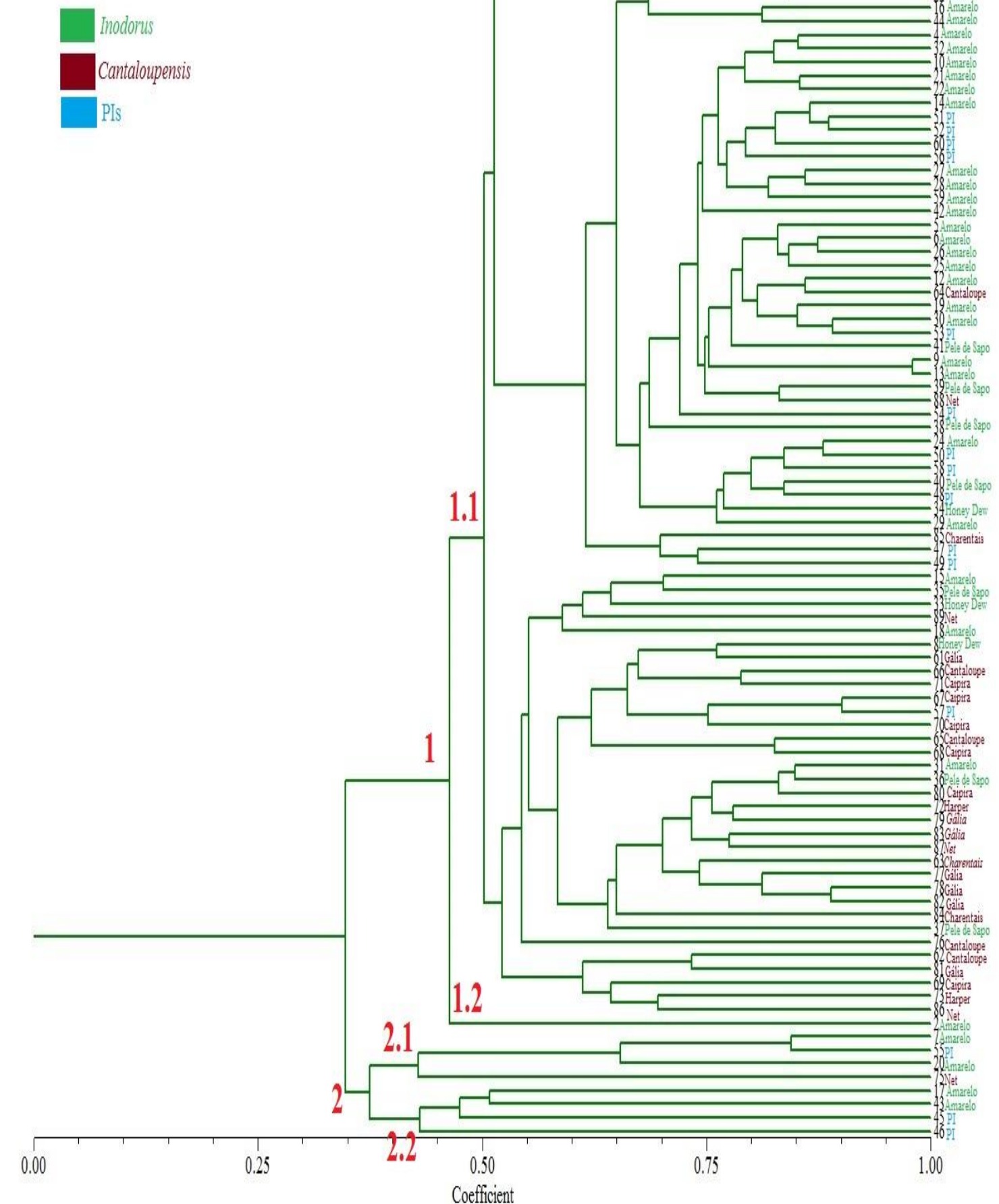

Figura 13: Dendrograma das 73 cultivares e 15 PIs gerado a partir da análise de 44 primers SSR. 1 e 2: Grupos principais; 1.1 e 1.2: Subgrupos do grupo 1; 2.1 e 2.2: Subgrupos do grupo 2. 
FACULDADE DE AGRONOMIA E MEDICINA VETERINÁRIA

Programa de Pós Graduação em Agronomia

\section{CONSIDERAÇÕES FINAIS}

Conclui-se que os 73 genótipos analisados têm ampla base genética, representando, portanto, grande fonte de variabilidade genética para o germoplasma nacional de cultivares comerciais. A cultivares Jangada (2) do tipo Amarelo (grupo Inodorus) e Cristobal (75) do tipo Net (grupo Cantaloupensis) destacaram-se sendo agrupadas individualmente, o que pode ser justificado pela presença de alelos raros, já que não foi observado nenhum alelo exclusivo desse genótipo. 
FACULDADE DE AGRONOMIA E MEDICINA VETERINÁRIA

Programa de Pós Graduação em Agronomia

\section{REFERÊNCIAS BIBLIOGRÁFICAS}

ARAGÃO de, F.A.S. Divergência genética de acessos e interação genótipo $\mathbf{x}$ ambiente de famílias de meloeiro. 2011. 137 f. Tese (Doutorado em Agronomia: Melhoramento Genético Vegetal). Universidade Federal Rural do Semi-Árido, Mossoró, 2011.

BOTSTEIN, D.; WHITE, R.L.; SKOLNICK, M.H.; DAVIES, R.W. Construction of a genetic linkage map in man using restriction fragment length polymorphisms. American Journal of Human Genetics, v.32, p 314-331, 1980.

BUSO, G.S.C. Marcadores Moleculares e Análise Filogenética. In: Marcadores moleculares e análise filogenética e Utilização de DNA na análise filogenética. Brasília: Embrapa Recursos Genéticos e Biotecnologia, 2005. p. 7-10.

CARVALHO, N.; CANELA, F.M.; FERREIRA, M.A.; OLIVEIRA, V.R.; SANTOS, M.F.; LEITE, P.H.S.; BUSO, G.S.C.; SOUZA, N.O.S. Análise da variabilidade genética de genótipos de melão utilizando marcadores moleculares SSR. In: SIMPÓSIO DE RECURSOS GENÉTICOS PARA A AMÉRICA LATINA E O CARIBE, 10. 2015, Bento Gonçalves. Resumos do... Bento Gonçalves: SIRGEALC, 2015.

FALEIRO, F.G. Marcadores Genético-moleculares - Aplicados a programas de conservação e uso de recursos genéticos. Planaltina - DF: Embrapa Cerrados, 2007. 99 p.

FERREIRA, M.E.; GRATTAPAGLIA, D. Introdução ao uso de marcadores moleculares em análise genética. Brasília: EMPRAPA-CENARGEN, 3ed. 1998. 220 p.

GAMA, R.N.CS.; SANTOS, C.A.F.; DIAS, R.C.S; SOUZA, F.F. 2013. Molecular characterization of watermelon cultivars using microsatellite markers. Horticultura Brasileira, v.31, n.4, p. 522-527, 2013.

GARCIA, E.; JAMILENA, M.; ALVAREZ, J.I.; ARNEDO, T.; OLIVER, J.L.; LOZANO, R. Genetic relatioships among melon breeding lines revealed by RAPD markers and agronomic traits. Theoretical and Applied Genetics, v.96, p. 878-885, 1998.

GOULÃO, L.; OLIVEIRA, C.M. Molecular characterisation of cultivars of apple (Malus $\times$ domestica Borkh.) using microsatellite (SSR and ISSR) markers. Euphytica.v.122, P.81-89, 2001.

GUERRA-SANZ JM. Citrullus simple sequence repeats markers from sequence databases. Molecular Ecology Notes, v.2, p.223- 225, 2002.

HENANE, I.; SLIMANE, R.B.; JEBARI, H. SSR-based genetic diversity analysis of Tunisian varieties of melon (Cucumis melo L.) and Fakous (Cucumis melo var. flexuosus). International Journal of Advanced Research, v. 3, n.3, p.727-734, 2015. 
FACULDADE DE AGRONOMIA E MEDICINA VETERINÁRIA

Programa de Pós Graduação em Agronomia

JARRET RL; MERRICK LC; HOLMS T; EVANS J; ARADHYA MK. Simple sequence repeats in watermelon (Citrullus lanatus (Thunb) Matsum. \& Nakai). Genome, v.40, p.433$441,1996$.

JOOBEUR T; GUSMINI G; ZHANG A; LEVI A; XU Y; WEHNNER TC; OLIVER M; DEAN RA. Construction of a watermelon BAC library and identification of SSRs anchored to melon or Arabidopsis genomes. Theoretical and Applied Genetics, v.112, p. 1553-1562, 2006.

KAÇAR, Y.A.; SIMSEK, O.; SOLMAZ, I.; SARI, N.; MENDI, Y.Y. Genetic diversity among melon accessions (Cucumis melo L.) from Turkey based on SSR markers. Genetics and Molecular Research , v. 11, n. 4, p. 4622-4631, 2012.

KALINOWSKI, S.T. et al., Revising how the computer program CERVUS accommodates genotyping error increases success in paternity assignment. Molecular Ecology, Oxford, v.16, n.5, p. 1099-1106, 2007.

KWON YS; OH YH; YI SI; KIM HY; AN JM; YANG SG; OK SH; SHIM JS. Informative SSR markers for commercial variety discrimination in watermelon (Citrullus lanatus). Genes \& Genomics, v.32, p.115-122, 2010.

LYNCH, M. The Similarity Index and DNA Fingerprinting.Mol Biol Evol, 1990.

MARSHALL, T.C.; SLATE, J.; KRUUK, L.E.B.; PEMBERTON, J.M. Statistical confidence for likelihood-based paternity inference in natural populations. Molecular Ecology.v,7, p. 639-655, 1998.

NEI, M. Molecular evolutionary genetics, New York: Columbia University, 1987, 284 p.

OHSE, B.J.G. Desenvolvimento de marcadores microssatélites (SSRs) para análise genética de melão (Cucumis melo L;). 2005. 33 F. Trabalho de Conclusão de Curso (Graduação em Biologia). Centro Universitário de Brasília, Brasília, 2005.

QUEIROZ, M.A. Germplasm of curcubitaceae in Brazil. Crop Breeding and Applied Biotechnology, v.4, p 377-383, 2004.

RITSCHEL, P.S.; LINS, T.D.de L.; TRISTAN, R.L; BUSO, G.S.C.; BUSO, J.A.; FERREIRA, M.E. Development of microsatellite markers from an enriched genomic library for genetic analysis of melon (Cucumis melo L.). BMC Plant Biology, v.4, n.1, p.9-24, 2004.

ROHLF, J.F. NTSYS-pc Numerical Taxonomy and Multivariate Analysis System, Version 2.2. New York, Exeter Publications. 1992.

SHIRAN, B.; AMIRBAKHTIAR, N.; KIANI, S.; MOHAMMADI, SH.; SAYEDTABATABAEI, B.E.; MORADI, H. Molecular characterization and genetic relantionship among almond cultivars assessed by RAPD and SSR markers. Scientia Horticulturae, v.111, p.280-292, 2007. 
FACULDADE DE AGRONOMIA E MEDICINA VETERINÁRIA

Programa de Pós Graduação em Agronomia

STAUB, J.E.; DANIN-POLEG, Y.; FAZIO, G.; HOREJSI, T.; REIS, N.; KATZIR, N. 2000 Comparative analysis of cultivated melon groups (Cucumis melo L.) using random amplified polymorphic DNA and simple sequence repeat markers. Euphytica 115: 225-241.

THIS P; JUNG A; BOCACCI P; BORREGO J; BOTTA R; CONSTANTINI L. Development of a standard set of microsatellite reference alleles for identification of grape cultivars. Theoretical and Applied Genetics, v.109, p.1448-1458, 2004.

TZURI, G.; PORTNOY, V.; DAUBE-MOZES, M.; KATZIR, N.Genetic Diversity of Melon (Cucumis melo L.) Estimated by SSR Markers. Cucurbit Genetics Cooperative Report. V. 28-29, P. 14-16, 2006. 